\title{
Complicity, Cause and Blame: A Study in the Interpretation of Doctrine
}

\author{
Sanford H. Kadish
}

TABLE OF CONTENTS

PAGE

I. The Concept of Blame......................... 329

II. ThE THEORY OF COMPLiCITY.................... 336

A. The Derivative Nature of the Liability.............. 337

B. The Action ................................ 342

1. Influence ............................. 343

2. Assistance ............................. 344

C. The Intention............................. 346

1. The Basic Requirement.................... 346

2. Strains in Application ...................... 349

3. Theory of the Intention Requirement ............ 353

D. The Result .............................. 355

1. Successful Contributions and Sine Qua Non Conditions .............................. 357

2. Minimal Contributions ..................... 361

3. Contribution Unknown to the Principal........... 364

4. Remote and Proximate Relationships Between

Contribution and Result.................... 366

III. Causing Actions.................................. 368

A. Nonculpable Actions ......................... 369

1. Theory of the Innocent-Agency Doctrine .......... 369

2. The Limits of the Innocent-Agency Doctrine ....... 372

B. Partly Culpable Actions ......................... 385

C. Unintended Actions ............................ 391

1. Nonvolitional Actions ...................... 392

2. Volitional Actions .......................... 398

Closing Comments ............................... 404 


\title{
Complicity, Cause and Blame: A Study in the Interpretation of Doctrine
}

\author{
Sanford H. Kadish $\dagger$
}

This is a study of a body of doctrine, the doctrine of complicity, that determines when one person is liable for a crime cominitted by another. Doctrine inay be studied in several ways depending on the question asked. One question asks what the doctrine is in some jurisdiction. This is the question primarily addressed by treatise writers. Another question asks whether the doctrine serves the purposes of the law and, to the extent it does not, how it should be altered. This is the question addressed by those engaged in revising the law. I do not inean that these questions can be answered independently of one another, only that they are different questions. In any event, the question this study addresses is distinguishable from both. It asks how the doctrine of complicity can best be interpreted as a coherent concept. This entails articulating the relationships between different parts of complicity doctrine and between coinphicity and other doctrines that are related to it, particularly causation, and identifying the general propositions that give logical and conceptual unity to the rules of liability. In short, the task is to develop the analytical framework that gives the doctrine of complicity its distinctive character. I niake no claini that what is here proposed is the only defensible interpretation of the doctrine of coniplicity. I offer it only as the best account I have been able to produce.

While the question of interpretation is distinguishable from the questions of what the doctrine is and what it ought to be, it is apparent that it cannot be addressed apart from these other questions. Consider first the question of what the law is. One can hardly undertake an inter-

$\dagger \quad$ Alexander and May T. Morrison Professor of Law, Boalt Hall School of Law, University of California, Berkeley. B.S.S. 1942, City College of New York; LL.B. 1948, Columbia Law School; Dr. Jur. (h.c.) 1983, University of Cologne. 1 wrote this Article while a Visiting Fellow at All Souls College, Oxford. I am grateful to the Warden and Fellows for allowing nie the privilege of their fellowship. I subsequently rewrote portions of it in light of helpful criticisn received at two conferences: the Conference on the Legal Philosophy of H.L.A. Hart, in Jerusalem in March 1984, and the German-Anglo-American Workshop on Basic Problenus in Criminal Theory, Max-Planck Institut für Ausländisches und Internationales Strafrecht, Freiburg-im-Breisgau, West Germany, July 1984. I am grateful to the participants for their generous help, as well as to other colleagues who have taken the trouble to read and coninent on earlier drafts. Since it would be pretentious to name them all and ungrateful to name only some 1 shall nanie none. Named or not, nyy debt to my friends is great, and I acknowledge it with profound appreciation. Students, however, are different. I wish to acknowledge my gratitude to Christopher Kennedy and Lindsee Granfield for their outstanding research assistance. 
pretation without describing, in soine sense, what it is that is being interpreted. This Article, therefore, presents a description of the law of complicity in common law jurisdictions to serve as the empirical basis of the interpretive enterprise.

At the same time, my description of the law differs in several ways from what one would expect to find in a hornbook or treatise. First, it does not attempt to depict the state of the law in any particular jurisdiction at any particular time. I have selected cases, commentary, and statutes from a variety of common law jurisdictions in order to identify the central problems of complicity and the dominant resolutions of those problems. Second, my principle of selection was not photographic faithfulness. While I hope I have neither distorted what courts have done nor omitted what did not suit my purpose, I caimot claim that my description is purely neutral. Interpretation and description are not wholly separate actions. They inform one another. My description of the law is inevitably affected by my interpretation of it. There is no escape. Finally, since my thesis is that the concept of complicity, reflected in the main body of common law decisions, entails some conclusions and forecloses others, I have felt free to conclude that certain propositions "must" represent the law, even where few, if any, cases have had occasion so to hold. Similarly, I have sometimes concluded that other propositions do not belong to the doctrine of coinphicity, even where some courts have announced them.

I inust also qualify my statement that I am not concerned with either judging the doctrine of complicity or proposing ways to improve it. I do not mean to imply that doctrine may be understood as soine disembodied thing that exists independent of social purposes or moral constraints. It is true that doctrine tends to have a life of its own. Considerations of consistency and coherence lead toward certain conclusions and away from others, quite apart from judgments of the social desirability of holdimg the defendant liable in particular cases. At the same time, no doctrine could long survive if it worked at cross purposes to the social objectives of the system of law in which it functioned. Unless the system were static and unresponsive, it would soon be replaced by new doctrine with new starting points. In the long run, the demands of consistency and coherence serve to give doctrine an independent life only to the extent that doctrine contmues to serve the purposes of law.

A further and deeper relationship between doctrine and normative considerations should be emphasized at the outset, because it suggests why doctrines of criminal liability are worth taking seriously despite the traditional American skepticism of doctrine. ${ }^{1}$ The decision to impose

1. For a discussion of a current revival of scholarly interest in taking doctrine seriously, see 
criminal liability is not governed solely by the social purposes of punishment. It is governed as well by the moral justification of punishing people for both their conduct and the results of their conduct. Indeed, criminal hability is best understood as responding primarily to considerations of the latter kind; the attainment of social purposes is confined, at least in most cases, to punishment for actions for which the defendant can be justly blamed. It follows that doctrines of criminal liability, being generalizations of the conditions in which punishment is proper, are primarily statements of normative import. Therefore, the kind of doctrinal interpretation attempted in this study-an analysis of the general propositions that give coherence to the body of rules governing liability in one area of the criminal law-necessarily entails an atteinpt to identify the nature of the pervasive intuitive judgments that render criminal liability acceptable in soine circuinstances, but not in others.

In his lecture The Path of the Law, Holines argued that the law is best understood from the lawyer's point of view by studying its actual operation, rather than its response to the infiuence of logic and morality. To this extent the focus of this study is distinctly un-Holmesian, since it is centrally concerned with the force of logical coherence and morality on the shape of doctrine. On the other hand, Holmes observed in the same lecture that the "law is the witness and external deposit of our moral life." If that is true of the law generally, it is surely true of legal doctrimes of criminal hability. My purpose in this Article is to see what we can learn, about the law and about ourselves, from a study of the moral deposit discoverable in the law of criminal complicity.

It inay be useful at the outset to present the reader with a brief summary of the major points of the arguinent.

Part I describes the conceptions of blame, responsibility, and causal responsibility inherent in our linguistic usages, social practices, and legal institutions. What is described, however, is not offered as the philosophically correct or most sophisticated analysis of those concepts. For present purposes, it is enough to determine what the concepts of blame, responsibility, and causation that underlie the criminal law are; we need not take a position on whetler the concepts presupposed by the criminal law are, in the final analysis, true.

Central among the beliefs that underlie the criminal law is the distimction between nature and will, between the plyssical world and the world of voluntary human action. Events in the physical world follow

Barnett, Contract Scholarship and the Reemergence of Legal Philosophy (Book Review), 97 HaRV. L. REV. 1223 (1984) (reviewing E.A. FARNSwORTH, CoNTRACTS (1982)).

2. O.W. Holmes, The Path of the Law, in Collected Legal Papers 167 (1920) (reprinting Holmes, The Path of the Law, 10 HARV. L. REv. 457 (1897)).

3. Id. at $\mathbf{1 7 0 .}$ 
one another with an inevitability, or natural necessity, that is conspicuously absent from our view of voluntary human actions. Voluntary human actions are not seen as the product of relentless forces, but rather as freely chosen expressions of will. Thus, the conception of causation appropriate to physical events is out of place in the human realm. Voluntary actions cannot be said to be caused in the physical sense that imports the images of relentless forces and necessary conditions.

These distinctions influence our conception of responsibility, mcluding, of particular significance for this Article, attributions of blame for untoward consequences of actions. The criminal law accommodates these distinctions by employing two separate bodies of doctrine to determine responsibility for results: causation, for the realm of nature, and complicity, for the realm of will. Causation applies where results of a person's action happen in the physical world. Complicity apphes where results take the form of another person's voluntary action.

Complicity emerges as a separate ground of hability because causation doctrine cannot in general satisfactorily deal with results that take the form of another's voluntary action. Causation doctrime encounters difficulties here because of the distinction between nature and will: The voluntary action of the principal actor cannot appropriately be said to have been caused (in the physical sense of cause) by the action of the secondary party (or accomplice). A voluntary action is treated as the terminal point of a causal inquiry beyond which the inquiry does not proceed. No one and nothing caused the principal's action. He freely and voluntarily chose to act.

Part II explores comphicity doctrime. Section $A$ describes the derivative character of complicity liability. That is, the liability of the accomplice depends upon the commission of an unlawful act by the primcipal. This dependency follows from the distinction between nature and will. Where the principal's actions are fully voluntary, the accomplice cannot be said to have caused the principal's actions, and thus cannot be held liable for the crime on the basis that he caused those actions. Complicity doctrine makes the accomplice liable for the unlawfulness of the primcipal's action. Absent that unlawfulness there is no basis for complicity liability.

A difficult question is what the legal status of the actions of the principal must be for the accomplice to incur liability. The obvious suggestion that the principal must be liable is shown to be incorrect by cases where the principal has a defense based upon policies extrinsic to his guilt (such as diplomatic immunity or entrapment), or where the principal's behavior is excused. The guilt of the principal would suffice to ground the liability of the accomplice where the principal has a policybased defense (extrimsic to his guilt) but will not suffice where the princi- 
pal is excused. Two theories that can handle cases where the primary party is excused are considered (each of which will play a prominent role later in the Article). First, one can resort to causation doctrine, as the early common law did, and hold the accoinplice directly liable as a principal who uses the primary party as a tool-an innocent agent-to commit the crime. Second, the accomplice's liability may be said to derive froin the wrongful act of the principal, even though that act was excused.

Section $B$ explains why it is that essentially only two foruns of action suffice for coinplicity-aid or influence-while, by contrast, any action that produces the result suffices for causation: only those two forns of contribution to the principal's actions are consistent with the volitional cliaracter of those actions.

Section $C$ develops the requireinent that the accomplice act intentionally. This Section explores the ineaning of the intention requirement, and the ways $i m$ which courts and legislatures sonietimes depart from it. It is suggested that the intention requireinent can be explained by the concept of the autonomy of human actions.

Section $D$ considers similarities and differences in the way causation and coinplicity doctrine lold a person accountable for what happens in consequence of his conduct. While both require a result, the relationship between act and result differs: Where the result is a physical event, causation requires at least a but-for relation. But where the result is a further action of another, coinplicity doctrine does not require that the sine qua non relation hold. The exploration of this paradox leads to the conclusion that in complicity the possibility of a but-for relationship is the analogue of the but-for relationship in causation. The inapplicability of necessary and sufficient conditions to the realm of the will, it is argued, explains this difference between causation and complicity.

Part III considers situations where causation doctrine complements complicity by serving as a ground of liability where coinplicity cannot. This occurs inainly in two kinds of cases, in both of which causation doctrine apphes because the primary party's action is not wholly voluntary. First, where the primary actor lias a defense that negates culpability, coinplicity doctrine lias difficulty because there is no basis for derivative liability. Insofar as the factors that negate the primary party's culpability also negate the voluntary character of his action, causation doctrine applies. Second, complicity doctrine fails where the secondary actor does not intend the crininal conduct of the primary party. Once again, causation complements complicity insofar as the primary party's action is not wholly volitional, since that fact allows tracing the result of the primary party's act back to the secondary party.

Part III also explains the limits of causation and complicity. In some cases, neither doctrine succeeds in explaining a liability that other- 
wise appears appropriate. This occurs, for example, where the nature of the prohibited actions, or the class of persons to whom the prohibition applies, precludes holding the secondary party directly liable where he uses the primary party as an innocent agent. Arguably, it occurs also where the secondary party unintentionally contributes to a wholly voluntary act by the primary party.

\section{I}

\section{The Concept of Blame}

Any attempt to account for the doctrine of complicity must begin with the concept of blame. Attributing blame is a pervasive human plienomenon. It is one way im which we order and make sense of social experience and it is reflected in our language and social practices. But it is also a concept that reaches so deeply into the jurisprudence of the criminal law that no account of the law can succeed witliout explicating its meaning and its role. The doctrine of complicity is founded on a particular sense of blame. However, it will be helpful in elucidating that special sense to consider the concept of blame in its broader context.

Blame and its correlative, praise, serve as expressions of our disapproval or approval of some human action or quality. We occasionally blaine things other than liuman actions, as when we blame an earth tremor for the fall of a picture from the wall. But these are only metaphorical usages-we often use a concept appropriate for a human action to vivify our account of why something liappened. We also sometimes praise an event or an object, as when we praise a painting of a sunset. But in this case, we are inferentially praising the actions of the painter. We would express approval of the sunset itself by speaking of its beauty, but we could not appropriately praise it.

There are important differences between praise and blame. First, praise can be given only when it is expressed, because it is intrinsically an expressive action. The sentiment of approval, experienced privately, becoines praise only when it is bestowed on someone. Blame is different. It is not intrinsically an expressive action, but a judginent of disapproval. It is an internal evaluation that need not be expressed. Blame is the sentiment of disapproval itself.

Second, significant differences exist between those actions suitable for praising, and tlose suitable for blaming. We are freer witl our praise than witl our blame. Praise is appropriate for any liuman action, aclievement, or quality of which we approve. We praise people for their virtue, but also for their beauty, strength, or special talent. Indeed, we praise people for any kind of action of which we approve, including acting rightly, but also including running a race, painting a picture, or solving a puzzle. Blame, on the other liand, is more restricted. For 
example, beauty may be praiseworthy, but lack of beauty is not necessarily blameworthy. Similarly, we may praise a runner for winning a race, but it does not follow that we may properly blame him for losing it.

The reason for these differences is that blame entails a judgment of responsibility, while praise does not. One who presents a poor appearance is not blamed for it unless he is responsible for it, as by poor judgment or lack of care in dress or grooming. The runner who loses a race may be blamed if he failed to train properly, but not if he did the best he could.

The notion of responsibility that underlies the concept of blame is an elusive one. Without attending to a variety of subtle complications that inhere in the concept, or arguing any particular philosophical position, we may say generally that blame imports the notion of choice. We perceive human actions as differing from other events in the world. Things liappen and events occur. They do not occur anarchically and haphazardly, but in sequences and associations that have a necessary quality about them. We express this quality in terms of causation and we understand it in terms of laws of nature that are beyond our power to alter. Human actions stand on an entirely different footing. While man is total subject under the laws of the natural world, he is total sovereign over his own actions. Except in special circumstances, he possesses volition through which he is free to choose his actions. He may be influenced in his choices, but influences do not work like wind upon a straw; rather, they are considerations on the basis of which he chooses to act. He may also be the object of influence in the larger sense that he is the product of the forces that shaped him. But his actions are his and his alone, not those of his genes or his rearing, because if he liad so desired he could have chosen to do otherwise. This is the perception that underlies the conception of responsibility which, in turn, is central to the conception of blame. We blame a person for an action that violates some approved norm of conduct. We not only disapprove of the conduct, we blame the person for it because he is a responsible agent with the power to choose to do otherwise.

The justification for this view of hunan action is the subject of the controversy over free will and determinism. The incompatibilists argue that this view of human action requires a conception of the will as uncaused-a singular exception to an otherwise determinate world. On the other liand, some compatibilists argue that this view of responsibility may adequately rest on our certain knowledge that we can do as we clioose so long as no pliysical force compels our action. Is freedom of the will grounded in reality, or is it an illusory by-product of our prejudices and ignorance? Is it enough that it is rooted in our subjective experience of ourselves not as straws in the wind, but as agents with our own identi- 
ties who define and act to achieve our own purposes? Since iny task is to identify and trace the effect of this perception on legal doctrine, I need not enter this controversy. However these questions are answered, it is enough for iny purposes to observe that the view of persons as responsible and autonoinous agents is a central feature of the concept of blaine; that without this concept of responsibility, moral judgment loses its essential character. The questions we must address are what blame entails and how far it helps account for the doctrines of the criminal law.

Blame has several senses, both in common usage and in the criminal law. In one sense, we inay blame a person for his actions. There are two prerequisites for fixing blame $\mathrm{m}$ this sense. First, the act must be subject to disapproval. If I am blamed for appearing late for an appointment, I may defend my action by explaining that I took time to help an injured friend get to the hospital. There is no doubt that I am responsible for what I did. My defense, mdeed, rests on it, because it asserts that what I did was the right thing to do, even if it meant being late. In short, I am not to be blained because what I chose to do was not blameworthy. This is the aspect of blame at issue in any legal defense of justification, such as self-defense, defense of another, enforcing the law, or the generalized defense of the choice of the lesser evil. This aspect of blame is also at issue when one tries to justify an action im moral norms outside the law, as in defending an action of civil disobedience.

A second prerequisite of this sense of blame turns on responsibility for the action, rather than justification for the action. Even if what the person did cannot be justified, he still inay not be blameworthy if his action, for a variety of possible reasons, was not a product of that freedom to do otherwise that the notion of blame imports. So, if my latecoining could not be justified, I might still question my blaneworthiness by appealing to this other aspect of blame. I might, for example, explain that I was locked into my building and it took time to find someone to let ine out. My defense here is excuse, which asserts that my freedom to have acted otherwise was totally or partially impaired.

The law provides for excuse through a variety of defenses. Soine defenses embrace situations in which the actor was without power to choose in the most literal sense-his movement was a reflex, or he was physically compelled or prevented. The law expresses this notion by requiring an act, taken to mean a voluntary act, as the indispensable requirement of any liability. In other situations the power of choice is not literally foreclosed but is so constrained that the action is excused. The law precludes hability in these cases as well, just as coinmon usage would preclude blane. Typical circunstances of this kind include those in which the actor was coerced by threat of injury (duress), or through no fault of his own, mistook the situation such that his action would have 
been unexceptionable had he taken it correctly (mistake), or where he was unable to exercise rational choice at all because of mental disease and was therefore beyond blame (legal insanity).

We inay also use blame in a different sense by blaining a person for something that occurs as a consequence of his action-that is, fixing blame for a result. An action may be blaineworthy in the first sense as an unjustified and unexcused action. But this would leave unanswered the different question whether the actor should be blamed for what follows froin his action. In this latter sense, responsibility is also involved, but not that sense of responsibility that turns on whether the person's power to act otherwise was impaired. Rather, it is a sense of responsibility for what follows froin a freely chosen action. Thus, the issue of excuse is inapposite. If I insult iny guest, who leaves in high anger and, distracted by the incident, walks into the path of an oncoming car, my responsibility for his injury will not turn on whether I should be excused for the injury. It would not make sense to speak of being excused for soinething that happens; we may be excused only for what we do. Here the question is whether the injury inay be attributed to my action, whether it can fairly be regarded as "belonging" to the action I chose to do. In common usage, as well as im the law, whether we may be blamed for something that results froin our actions turns on whether we may be said to have been the cause of that result, or to be blameable for it on some related ground.

A consequence of a person's action inay be of two general kinds. It inay consist of subsequent events. If I light a inatch in an area containing explosive vapors that ignite, starting a fire that burns down a building, I may be blamed for the burning of the building because I can be said to have caused it. I started a chain of events that led to the burning of the building through cause and effect relationships governed by laws of nature. ${ }^{4}$ But a consequence of a person's action inay also consist of the actions of other people. I may have persuaded another responsible person to light the inatch or helped hin by giving hin a match for the purpose. The other person then caused the burning of the building. But whether I am to be blamed for the other person's action would not be assessed by asking whether I caused his action in the same sense that his highting the inatch caused the fire. Rather, iny responsibility would be determined by asking whether my persuasion or help inade me accountable for the other person's actions and what they caused.

Responding to these cominon perceptions of the relationship

4. This also may not be enough, but it is always necessary, except in the instance of multiple independent and sufficient conditions. See 1 NATIONAL COMM'N ON REFORM OF FEDERAL CRIMINal Law, Working Papers 144-46 (1970); McLaughlin, Proximate Cause, 39 Harv. L. Rev. 149, 153-54 (1925). 
between actions and consequences, the criminal law has developed two separate doctrines for fixing blame. The doctrine of causation deals with fixing blame for natural events. The doctrine of complicity deals with fixing blame for the criminal action of another person. While the doctrine of complicity is the subject of this Article, the doctrine of causation cannot be put aside. For though there are significant contrasts between causation and complicity, there are also important similarities deriving from the common function of both doctrines to fix blame for consequences. In comparing and contrasting these doctrines, I shall draw heavily on the classic treatment of causation by Professors Hart and Honoré. 5

At the outset, it is important to develop more fully why both in common usage and in law we use different concepts to determine when a person may be blamed for things that happen and when he may be blamed for what other people do. The explanation hes in that singular view of human action that underhes blame. That same view of human action that entails freedom to choose obviously applies to the actions of one who is responding to the actions of another. In the same sense and for the same reasons that a person's genes, upbringing, and social surroundings are not seen as the cause of his actions, neither are the actions of another seen as the cause of his actions. We regard a person's acts as the products of his choice, not as an inevitable, natural result of a chain of events. Therefore, antecedent events do not cause a person to act im the saine way that they cause things to happen, and neither do the antecedent acts of others. To treat the acts of others as causing a person's actions (in the physical sense of cause) would be inconsistent with the premise on which we hold a person responsible.

There are exceptions to this general perception of human action that need to be noted here because they figure in the play between the doctrines of complicity and causation. Certain kinds of actions are in fact treated as caused by a prior action of another because we deein them lacking that quality of unconstrained free choice that generally characterizes hunan actions. Following Hart and Honore, we may refer to these as nonvoluntary (or nonvohitional), or not wholly voluntary (or not wholly volitional) actions. ${ }^{6}$ Of course, an involuntary action, which in law is not regarded as an action at all, is of this character. But the class of nonvolitional actions, in the sense developed by Hart and Honoré, includes actions that are not hiterally involuntary. It includes all actions that are not wholly unconstrained or that are done without knowledge of those relevant circumstances that give the action its significance. There are two principal circumstances in which we treat human actions as

5. H.L.A. Hart \& A. Honoré, CaUSATION IN THE LAw (1959).

6. Id. at 296. 
nonvolitional: where they are excusable and where they are justifiable. Actions of persons who are legally irresponsible, actions where the actor acts without a required mens rea or where other factors betoken absence of free choice (for example, duress), constitute excusable actions. Actions required by duty (i.e., a police officer's attempt to enforce the law) and actions constrained by the predicament of self-defense are examples of justifiable actions. As Hart and Honore have shown, there are a variety of otler circumstances as well where actions are not regarded as sufficiently volitional to warrant treating them the way human actions are normally treated. ${ }^{7}$ But since they are rarely relevant to the kinds of problems discussed in this Article, they may be put aside.

I do not mean to say that the language of causation is inappropriate when dealing with one person's influence on the actions of another even when the latter's actions are entirely volitional. We commonly speak of one person occasioning the actions of anotler or of one person's action being the result of what another person says or does. This is appropriate because causation, broadly conceived, concerns the relationship between successive plienomena, whether they liave the character of events or happenings, or of another person's volitional actions. The point I mean to stress is that in dealing witl the influence of one person upon the actions of anotlier, we refer to a different kind of causal concept than that involved in pliysical causation. ${ }^{8}$ However philosophers may dispute the point, ${ }^{9}$ as far as the law is concerned, the way in whicl a person's acts produce results in the physical world is significantly different from the way in which a person's acts produce results that take the form of the volitional actions of others. The difference derives from the special view we take of the nature of a liuman action. In the course of this Article, therefore, I will use causation restrictively to refer to relationships in whicl succeeding events take the form of liappenings, exclusive of individuals' volitional actions.

This view of volitional luman action lias two relevant implications for understanding the doctrine of complicity. First, when we examine a sequence of events that follows a person's action, the presence in the sequence of a subsequent luman action precludes assigning causal

7. Id. at 296-303.

8. One of the significant contributions of Hart and Honore's Causation in the Law is their identification and development of this distinction between causation of physical cvents and occurrences and causation of human actions ("interpersonal transactions" where "we have to deal with the concept of reasons for action rather than causes of events"). Id. at 48 (emphasis in original).

9. Professor Mackie took a different view that stresses the similarities in these two kinds of causal statements. J. MACKIE, THE CEMENT OF THE UNIVERSE 117 (1980). Whether or not Mackie is right, the premise that these modes of causation are significantly different is implicit in the structure of complicity and causation doctrine in the law, as much of this Article is designed to show. 
responsibility to the first actor. What results from the second actor's action is something the second actor causes, and no one else can be said to have caused it through him. This is expressed in the familiar doctrine of novus actus interveniens. ${ }^{10}$ Second, when we seek to determine the responsibility of one person for the volitional actions of another, the concept of cause is not available to determine the answer. For whatever the relation of one person's acts to those of another, it cannot be described in terms of that sense of cause and effect appropriate to the occurrence of natural events without doing violence to our conception of a human action as freely chosen. ${ }^{11}$

These two implications of how we conceive of human actions give rise to the doctrine of complicity in the following way. Criminal prohibitions take two principal forms. Most prohibitions threaten punishment for particular kinds of actions (of course, with defined mens rea), sometimes only when some harm eventuates from the action, but sometimes whether it does or not. Examples of this form of prohibition include appropriating another's property, receiving stolen goods, breaking and entering defined structures, obtaining property by false pretenses, having sexual relations with another against her will, and killing a person in the course of operating a motor vehicle. On the other hand, we may pumish a person for causing some defined harm, with no further description of the action prohibited: causing the death of a human being (killing) is the most common example. To be guilty of the first kind of crime (action crimes) the person charged must engage im the particular kinds of activ-

10. See G. Williams, Textbook on Criminal Law 390-93 (2d ed. 1983); see also Lewis v. Commonwealth, 19 Ky. 1139, 42 S.W. 1127 (1897); People v. Elder, 100 Mich. 515, 59 N.W. 237 (1894).

11. In Causation in the Law, Hart and Honore express these basic ideas in the following language: A volitional action, they say, "has a special place in causal inquiries . . . because, when the question is how far back a cause shall be traced through a nuinber of intervening causes, such a voluntary action very often is regarded both as a limit and also as still the cause even though other later abnormal occurrences are recognized as causes." H.L.A. HART \& A. HoNORE, supra note 5, at 39. Further, "A deliberate human act is therefore most often a barrier and a goal in tracing back causes in such inquiries: it is something through which we do not trace the cause of a later event and something to which we do trace the cause through intervening causes of other kinds." Id. at 41 (emphasis in original). And, "[t]he voluntary intervention of a second human agent . . . is a paradigm among those factors which preclude the assimilation in causal judgments of the first agent's connexion with the eventual harm to the case of simple direct inanipulation." Id. at 69.

Hart and Honoré's conclusion that intervening volitional actions uniquely affect coinmonsense attributions of causal responsibility has been challenged. See J. FeinBerG, Causing Voluntary Actions, in DOING AND DESER VING 152 (1970). Feinberg argues that it is the lighly unusual character of an intervening occurrence, whether a volitional action or a natural event, that is responsible for the conception of a superseding cause, and he offers some forceful counterexamples to the Hart and Honore position. Id. at 166-67. But, as the argunent in this Article attempts to show, the Hart and Honoré position serves as a powerful tool for understanding and aecounting for the law of complicity and its relation to causation. Part of the difference between Feinberg and Hart and Honoré inay be that Feinberg has chiefiy in mind explanatory causal statements, while Hart and Honoré are solely concerned with statements that attribute causal responsibility. Id. at 181-84. 
ity prohibited. To be guilty of the second kind (result crimes), he must be found to have caused the result, by any actions that suffice to do so.

How then can the law reach those whose conduct makes it appropriate to pumish them for the criminal actions of others-a person, for example, who persuades or helps another to commit a crime? Such persons do not commit action crimes, since they do not engage in the prohibited action. Some general doctrine is required through which such persons may be found hable. But what forn should the doctrine take? If it were not for the very special way in which we perceive human actions, causation doctrine might serve this purpose, on the view that one who causes another to commit certain actions falls under the prohibition against committing those actions. But our conception of human actions as freely chosen precludes this analysis. Some alternative doctrine is needed, therefore, that imposes hability on the first actor who is to blame for the conduct of another, but that does so upon principles that comport with our conception of human actions. This is the office of the doctrine of complicity.

What then of result crimes? It agam follows from our view of liuman actions tliat causation doctrine cannot inake the first actor liable for a prohibited result caused by a volitional act of the second actor. As Hart and Honore put it, the latter's action serves as a barrier through which the causal inquiry cannot penetrate to hold the first actor liable. ${ }^{12}$ To hold the first actor for the crime, we need an alternative doctrine that is consistent witl our conception of liuman actions. The doctrine of complicity also fills the doctrinal gap for result crimes.

II

\section{THE THEORY OF COMPLICITY}

For the reasons just presented, the doctrine of complicity (sometimes referred to as the law of aiding and abetting, or accessorial liability) emerges to define the circuinstances in which one person (to whom I will refer as the secondary party: or actor, accomplice, or accessory) becomes liable for the crime of another (the primary party or actor, or the principal). ${ }^{13}$ To develop the theory of complicity further, it is necessary now to consider: (A) the nature of the liability imposed on the secondary party, (B) the kinds of actions that create this liability, (C) the intention with

12. H.L.A. HART \& A. HoNORE, supra note 5, at 69.

13. I am putting to one side the exceptional cases of vicarious liability in which one is made to share in the liability of another without regard to the doctrine of complicity. These cases represent judgments of the social desirability of holding persons liable im particular situations notwithstanding the doctrinal principles that otherwise would govern. See generally Sayre, Criminal Responsibility for the Acts of Another, 43 HARv. L. REv. 689 (1930). 
which those actions must be committed, and (D) the relevance of the success of those actions in achieving their objective.

\section{A. The Derivative Nature of the Liability}

The nature of complicity hability follows from the considerations that called it forth. The secondary party's hability is derivative, ${ }^{14}$ which is to say, it is incurred by virtue of a violation of law by the primary party to which the secondary party contributed. It is not direct, as it would be if causation analysis were applicable. That is ruled out by our concept of human action, which imforins much of complicity doctrine. Volitional actions are the choices of the primary party. Therefore they are his acts and his alone. One who "aids and abets" him to do those acts, in the traditional language of the common law, can be hable for doing so, but not because he has thereby caused the actions of the principal or because the actions of the principal are his acts. His hability must rest on the violation of law by the principal, the legal consequences of which he incurs because of his own actions.

It is important not to misconstrue derivative hability as imparting vicarious liability. Accomplice liability does not involve imposing hability on one party for the wrongs of another solely because of the relationship between the parties. Liability requires action by the secondary actor-as we shall see, intentional action designed to persuade or helpthat makes it appropriate to blaine him for what the prinary actor does. The tern "derivative" as used here merely means that his hability is dependent on the principal violating the law. What is at issue is the responsibility of the secondary actor for the principal actor's violation of law. Unless the latter occurs there can be no accomplice hability. Perhaps "dependent" would be a better tern. I choose derivative because it has gained soine currency.

So understood, the notion of derivativeness can be expressed as well in terns of the requirement of a result: just as causation doctrine requires that the prohibited result occur before there can be an issue of the actor having caused it, so in complicity doctrine there must be a violation of law by the principal before there can be an issue of the secondary party's hability for it.

The most troublesome aspect of the concept of derivative liability is defining the legal status of the principal's actions required to impose hability on an accomplice who aids or encourages him. So far, I have defined it loosely as a violation of law by the principal in order to avoid prejudging the question of low that legal status should be more precisely defined. That question must now be pursued.

14. G. FletCher, Rethinking CRIMINAL LAW 634-49 (1978). 
The traditional formulation of derivative liability finds the source of secondary party liability in the liability of the prinary party. On this view, the liability of the secondary party derives from that of the primary party. The former sliares the latter's liability because he contributed to the actions of the primary party that gave rise to the latter's liability. This lias becoine a central axion of complicity liability. As the Second Circuit recently stated, "It is hornbook law that a defendant charged witl aiding and abetting the commission of crime by anotler cannot be convicted in the absence of proof that the crime was actually committed."15 An Enghish court gave the principle pungent expression in reversing a conviction of a bus conductor for aiding and abetting the bus driver's careless driving. The conductor had carelessly signaled the driver (who could not see to his rear) that it was safe to back up. In fact, it was not, because passengers were disembarking, and several were struck. Since the driver had been acquitted of negligent drivingbecause his reliance on the conductor was not negligent-the conviction of the conductor as his aider and abetter became insupportable: "In one breath [the trial justices] say that the primcipal did nothing which he slould not have done, and in the next breath they loold that the bus conductor aided and abetted the driver in doing something which he had not done ...."16

The derivative nature of the secondary party's liability explains a variety of outcoines in the law of complicity. It is well settled that a secondary party is liable as an accomplice for influencing or aiding another to commit a crime that the secondary party is not himself capable of committing. ${ }^{17}$ An unmarried man, for example, cannot himself commit bigamy, because that crime extends only to those who, already married, marry agam. ${ }^{18}$ But lie can be convicted of bigamy as an accom-

15. United States v. Ruffin, 613 F.2d 408, 412 (2d Cir. 1979); accord Shuttlesworth v. Birmingham, 373 U.S. 262, 265 (1963) ("It is generally recognized that there can be no conviction for aiding and abetting someone to do an innocent act."); see cases cited in Ruffin, 613 F.2d at 412; United States v. Jones, 425 F.2d 1048, 1056 (9th Cir.) ("[T]here must be a guilty principal before there can be an aider or abettor."), cert. denied, 400 U.S. 823 (1970); Surujpaul v. The Queen, [1958] 1 W.L.R. 1050; Morris v. Tolman, [1923] 1 K.B. 166; Cain v. Doyle, 72 C.L.R. 409 (Austl. 1946); 1 J. TURNER, RUSSELI ON CRIME 128 (12th ed. 1964) [hereinafter cited as RuSSELl ON CRIME]:

[W] hen the law relating to principals and accessories as such is under consideration there is only one crime, although there may be more than one person criminally liable in respect of it .... There is one crime, and that it has been committed nust be established before there can be any question of criminal gnilt of participation in it.

See also Lanham, Accomplices, Principals and Causation, 12 Mel b. U.L. REv. 490, 490 n.3 (1980).

16. Thornton v. Mitchell, [1940] 1 All E.R. 339, 341. I will consider later whether the conductor could be convicted as a principal under sone other doctrinal alteruative. See infra note 143 and accompanying text.

17. See W. LaFave \& A. Scott, Handbook on Criminal law 520-21 (1972); 1 C. TORCIA, Wharton's CRIMINaL LAW 186 (14th ed. 1978) [hereinafter cited as Wharton's CRIMINal LAW].

18. It is otherwise, of course, when bigamy is statutorily extended to include an ununarried 
plice for aiding or mfluencing a married person to commit the crime. ${ }^{19}$ Where a husband is incapable of raping his own wife, he may nonetheless be liable for her rape by another if he helps or encourages the other to do the act. ${ }^{20}$ Liability in these cases follows logically from the premise that the liability of the secondary party rests on the liability of the primary party. Since the secondary party could not be held for violating the law himself, his liability must be derivative.

The conventional derivative hability principle is also evident im cases in which one person helps another commit a crime, not realizing that the other is only feignimg for the purpose of ensnaring him. For example, suppose a person boosts an ostensible principal into a window and the latter, having previously arranged for the police to arrive, and actimg without the intent to steal required for burglary, passes out property to his helper. The helper is not liable as an accomplice so long as the feigning principal has incurred no hability by his actions, ${ }^{21}$ since the secondary party's liability derives from that of the primary party.

The relation between the degree of liability of the secondary party and that of the primary party likewise evidences the principle that an accomplice's liability derives from that of the primary party. It is widely accepted that the secondary party's liability need not be as great as that of the principal, ${ }^{22}$ who may have acted with a mens rea that makes him inore culpable than the secondary party. The latter, for example, may, in the heat of provocation, induce the primary party to kill, while the primary party may act with cool deliberation. ${ }^{23}$ But this does not contra-

person who knowingly marries a person already married. See, e.g., CAL. PENAL CoDE $\$ 284$ (West 1984).

19. See Boggus v. State, 34 Ga. 275 (1866); see also State v. Warady, 78 N.J.L. 687, 76 A. 977 (1910).

20. In re Kantrowitz, 24 Cal. App. 203, 140 P. 1078 (1914); Cody v. State, 361 P.2d 307 (Okla. Crim. App. 1961). So also may a woman be guilty of rape as an accomplice to the rape of another woman by aiding a man to commit the crime, even in a jurisdiction where only a man can commit rape. People v. Reilly, 85 Misc. 2d 702, 709, 381 N.Y.S.2d 732, 739 (1976); WHARTON's CRIMINAL LAw, supra note 17 , at 188 \& n.87.

21. See State v. Hayes, 105 Mo. 76, 16 S.W. 514 (1891), overruled on other grounds by State v. Barton, 142 Mo. 450, 44 S.W. 239 (1898); Topolewski v. State, 130 Wis. 244, 109 N.W. 1037 (1906); Regina v. Johnson \& Jones, Car. \& M. 218, 174 Eng. Rep. 479 (1841); Rex v. Eggington (1801), reported in 2 E. EAST, PLEAS OF THE CROWN 666 (1806); see also Parties, Complicity and Liability for the Acts of Another, in THE LAw COMM'N, Working PAPER No. 43, at 11-13 (England 1972) (Proposition 3). Of course the helper could be held liable as a principal if any of his own actions constitutes the crime of burglary. Moreover, even in the situation supposed in the text, where this is not the case, there is the possibility of liability for attempt to be an accomplice. See infra text accompanying notes 82-84.

22. See, e.g., United States v. Paszek, 432 F.2d 780 (9th Cir. 1970), cert. denied, 402 U.S. 911 (1971); G. Williams, Criminal Law, The General Part 390 (2d ed. 1961) (discussing differing degrees of liability for primary and secondary parties).

23. People v. Blackwood, 35 Cal. App. 2d 728, 733, 96 P.2d 982, 985 (1939); Thomas v. State, 73 Fla. 115, 122, 74 So. 1, 3 (1917); Speer v. State, 52 Ga. App. 209, 209, 182 S.E. 824, 824 (1935); State v. Lord, 42 N.M. 638, 657-58, 84 P.2d 80, 96 (1938). 
dict the conception of the secondary party's liability as derivative. The accomplice's liability derives from that of the principal no less because it may derive from some and not all of his liability. These cases do not require attributing to the accomplice the volitional actions of the principal, only his (or some of his) liability. They are therefore consistent witl the basic premise of complicity liability.

On the other liand, if tle accomplice's liability derives from that of the principal, the liability of an accomplice could not exceed that of the principal. ${ }^{24}$ However, there are situations in which a secondary actor's liability surely sliould exceed that of the primary actor. Suppose the instigator with cool dehberation provokes anotlier person to kill in loot blood. The classic instance is Iago coolly whipping Otlello into inurderous rage. One way to justify a higher liability for Iago is througli the doctrine of causation, as we sliall later see. ${ }^{25}$ Anotlier way to sustain hability in this situation is to reconceive the traditional theory to rest tle accomplice's liability on some ground other than the liability of the principal. I will consider shortly what ground that might be. But it is helpful first to consider the extent to which the traditional theory is otherwise in need of repair.

The theory that accomplice liability is altogether controlled by the principal's liability was once taken quite literally. In an early day the common law required the principal to lave been convicted before his accomplice could be convicted. This was abandoned by Blackstone's time. ${ }^{26}$ It was enough that the principal be proven liable in the trial of the accomplice; his hability need not have been previously established. Subsequent decisions and statutes determined that the accomplice may be liable even when the principal had been tried and acquitted in an earlier trial. ${ }^{27}$ This result is consistent with the traditional theory on the view that the principal's acquittal establishes his innocence only in the sense that lie may not be punislied. The acquittal may liave been the product of difficulties of proof at his trial or of the vagaries of jury factfinding. Double jeopardy precludes trying liim a second time. But there is no reason why it should preclude proof of his guilt in a subsequent trial of his accomphice. ${ }^{28}$ These developments require a cliange in formulation, if not im concept, of the traditional view. It would seem more accurate to say that what grounds the liability of the accomplice is the

24. See, e.g., Regina v. Richards, [1974] 1 Q.B. 776 (discussed infra at text accompanying notes 199-205); see also $4 \mathrm{~W}$. BLACKSTONE, COMMENTARIES *36.

25. See infra text accompanying notes 186-205.

26. $4 \mathrm{~W}$. BLACKSTONE, supra note 24 , at $* 40$.

27. See Standefer v. Umited States, 447 U.S. 10 (1980); Regina v. Humphreys \& Turner, [1965] 3 All E.R. 689; G. Williams, supra note 22, at 407.

28. See Model Penal Code $\S 2.04(6)$ comment at 38 (Tent. Draft No. 1, 1953). 
liability of the principal at the time he acted, even though it was not and could no longer be imposed upon him.

This is a minor change, but it is not quite enough to account for accomplice hability in a somewhat different class of cases. Sometimes the principal, though having violated the law with the required mens rea and without excuse or justification, enjoys some special defense that would have precluded his conviction at any time. The principal, for example, may enjoy a defense of diplomatic immumity ${ }^{29}$ or entrapment. ${ }^{30}$ There seems no reason not to impose accomplice liability upon a person who helps him. The legal defense precludes convicting the primary party for reasons of policy that are mapplicable to convicting the secondary party. But to liold the helper as an accomplice requires an even greater modification of the traditional theory. The reason the principal camiot be held liable is not evidentiary, but substantive; since the law gave him a defense, he never was subject to liability. If the theory of derivative hability is to be preserved, therefore, it must rest not on the principal's liability or potential liability, but on a sense of guilt divorced from liability. The principal must be regarded as guilty because he violated the law with the required mens rea and without excuse or justification, and his guilt im this sense is not negated by the legal defense. In other words, the principal's guilt is wliat the accomphice shares because he contributed to the principal's actions. As one court put it, the principal's defense of entrapment " is made available not because inducement negatives criminal intent and thus establishes the fact of innocence, but because Government agents sliould not be perimitted to act in such a fashion. The defense does not so much establish mnocence as grant immunity from prosecution for criminal acts concededly committed. '"31

But even this modification of the traditional theory may be inadequate where the principal is not liable because he is excused, rather than because he has some defense based on policies extrinsic to his guilt. Suppose, for example, the primary actor acted under the duress of a third party, was legally irresponsible, or, because of a reasonable mistake, believed he was doing something harmless. Under the theory of accomplice liability that derives liability from the guilt of the principal, one who culpably helps or instigates such a principal would apparently not be liable as an accomplice because the principal is not guilty. And yet, if it were not for these defenses, which are not as such available to the secondary actor, the actions that he helped the principal perforin would be criminal. The secondary actor's culpability is surely unaffected by the

29. Cf. Farnsworth v. Zerbst, 98 F.2d 541 (5th Cir. 1938) (defendant may be hable despite acquittal of coconspirators on ground of diplomatic immunity).

30. See United States v. Azadian, 436 F.2d 81, 82-83 (9th Cir. 1971).

31. Id. at 83 (quoting Carbajal-Portillo v. United States, 396 F.2d 944, 948 (9th Cir. 1968)). 
fact that the principal has an excuse. Therefore, some doctrinal adaptation is needed to avoid the absurdity of acquitting the defendant in these cases.

The common law's early response was to resort to causation doctrine. Simce the acts of the primary party are excused and hence not fully volitional, they can be treated as caused by the actions of the secondary party. Liability is justified by regarding the secondary party as a principal and the primary party a tool-an innocent agent-that he uses to commit the crime. I will deal more fully witl the innocent-agency doctrine later in this Article, as one of several ways in whicl causation doctrine is used to supplement accomplice doctrine when it fails to inculpate culpable actors. ${ }^{32}$ I mention it at this point in order to call attention to the possibility of an alternative move that has not been taken in AngloAmerican law. In some foreign jurisdictions, the secondary party is treated as an accomplice notwithstanding the absence of a guilty principal. The theory is that thougli excused, the primary party did a wrongful act prohibited by the law; the liability of the secondary party derives from the principal's innocent wrongdoing.

This sounds strange to common law ears, and one may wonder why it even needs to be considered in light of the availability of the innocentagency doctrine. The reason is that the innocent-agency doctrine may prove less than fully adequate to solve the Iago problem. ${ }^{33}$ Moreover, it may fail entirely $m$ some cases where tlie innocence of the principal precludes accomplice liability on traditional grounds. I will tell that story subsequently and, in the course of it, consider furtlier the case for modifying accomplice liability im a way that makes it sufficient for a primary party to have done a wrongful act, even though he is excused and therefore innocent. ${ }^{34}$

\section{B. The Action}

Two kinds of actions render the secondary party liable for the criminal actions of the primary party: imtentionally influencing the decision of the primary party to commit a crime, and intentionally helping the primary actor commit the crime, where the helping actions themselves constitute no part of the actions prohibited by the definition of the crime. These commonly overlap, because knowledge that aid will be given can influence the principal's decision to go forward. Moreover, the legal consequences are the same whichever mode of participation is involved. Nonetheless, an analytic difference remains: in cases of influence, the secondary actor's liability derives from his contribution to the principal's

32. See infra pp. 369-72.

33. See infra text accompanying notes $187-98$.

34. See infra text accompanying notes $\mathbf{1 7 0 - 7 6}$. 
decision to commit the crime; in the other, his liability is based on the assistance he gives him in executing the crime.

Various terms are used to capture the central notions of assistance and influence. Assistance is sometimes expressed as helping, aiding, or abetting. Liability never turns, however, on the choice among these terms. All embrace ways in which one person may help another commit a crime, including furmishing means, whether inaterial or informational, providing opportunities, and lending a hand in preparation or execution. Influence is expressed in a greater variety of terms, sometimes with overlapping ineanings, sometimes with different connotations. Advise, like counsel, imports offering one's opimion in favor of some action. Persuade is stronger, suggesting a greater effort to prevail on a person, or counseling strongly. Command is even stronger, implying an order or direction, commonly by one with some authority over the other. Encourage suggests giving support to a course of action to which another is already inclined. Induce means to persuade, but may suggest influence beyond persuasion. Procure seeins to go further, suggesting bringing something about in the sense of producing a result. Instigate as well as incite suggest stirring up and stinulating, spurring another to a course of action. Provoke is roughly equivalent to imcite, with the added sense of producing a response by exploiting a person's sensitivities. Solicit is generally equivalent to incite in legal usage, although im common usage it suggests simply asking or proposing.

These differences in emphasis and connotation rarely have legal significance. All of these terms describe ways of influencing a person to choose to act in a particular way and therefore constitute a ground of complicity. Occasionally, however, the precise form of influence affects the legal conclusion, most often where statutes einploy one or more of these terms restrictively. I shall use the term "influence" coinpendiously, to cover all these ways of affecting another person's decision to act.

\section{Influence}

Holding a secondary party liable for influencing the principal's decision to act is plainly compatible with the premise that the latter's acts are determined by his own choice. Recognizing that a person is imfluenced by what other people say and do, just as a person is influenced by all his experiences, does not imply that volitional actions are caused, in the plysical sense, the way natural events are determined by antecedent conditions. The choice of the primcipal is what ultimately determines the effectiveness of the influence.

As Hart and Honore have pointed out, the characteristic form of influencing another is the giving of reasons for an action. This differs from causal influence in that the influence operates not as a determining 
condition, but as a consideration that renders a particular course of action more desirable to the primary actor. ${ }^{35}$ If one persuades or encourages another to commit a criminal act by appealing to some consideration that moves him, by giving him emotional support and approval, by offering a rationalization for the action, or by similar means, one has not caused the principal to act in the physical sense of cause. These influences did not make the principal act, for he was free to act as he chose. Nonetlieless, since the secondary party intentionally initiated the influences in order to induce the principal to act, he may be held liable. This is a coininonplace ground for blaming a person in ordinary experience and is reflected in the legal doctrine of complicity.

\section{Assistance}

Liability for helping another coinmit a crime is likewise compatible with the concept of a volitional action. To say that one may assist another to carry out his intended actions is, of course, not to imply that lie caused those actions. Again, the acts the principal does toward commission of the crime represent his own choices. What, then, arc the kinds of lielping actions that make a person hable as an accomplice?

In soine cases where two or more actors contribute to a criminal act, the problem of secondary party liability does not arise. For example, when each of the parties does all the acts constituting the crime, each has committed the crime and is liable as a principal in his own right. Nor does the issue of secondary party liability arise where one does all and the otlier some of the acts constituting the crime-as where two inen hold a victim at gunpoint and one of thein takes his wallet. Both are primary parties committing the crime of robbery. The saine is true where neither of the parties commits all the acts constituting the crime but together they do, as where one holds a viction at gunpoint while the other, unarined, takes lis wallet. So long as each person commits some of the actus reus of the crime and, acting jointly, they succeed in committing the crime, eaclı is liable as a coprincipal. ${ }^{36}$

35. H.L.A. HART \& A. HoNORE, supra note 5, at 338.

36. See, e.g., State v. Weis, 92 Ariz. 254, 375 P.2d 735 (1962) (both defendants guilty as principals where one defendant wrote bad check and other defendant, with knowledge of its falsity, used the check to buy merchandise at a shop), cert. denied, 389 U.S. 899 (1967); Regina v. Kelly \& M'Carthy, 2 Car. \& K. 379, 175 Eng. Rep. 157 (1847) (where one defendant took victim's property and hid it on the other defendant's tram, and where the other defendant then took away that property, both defendants were principals in larceny); Cornwall's Case, 2 Strange 881, 93 Eng. Rep. 914 (1730) (servant who let thief into his master's house found guilty of burglary); $c f$. the restatement of the English law proposed by the Criminal Code Commissions, which makes everyone a party to and guilty of an indictable offense who "[a]ctually commits the offence, or does . . . any act the doing .. . of which forms part of the offence." 2 J. STEPHEN, A History OF THE CRIMINAL LaW of ENGLAND 236 (1883).

This concept of coprincipal liability is not harmonious with the distinction between direct and 
The problem of the secondary party's liability does arise where one of the parties commits all the acts necessary for the crime and the other does none of these acts but renders some assistance, typically by providing the means or opportunity. The secondary party may serve as lookout, or drive the getaway car, or hold a ladder, or perform numerous other tasks that help the primary party execute the crime. ${ }^{37}$ He may also help at the preparation stage, for example, by providing the primary party with some needed material or information. ${ }^{38}$ These cases require a special concept of complicity in order to make the helper hable, since his role in each is altogether secondary-he himself does none of the acts constituting any part of the crime.

In both these modes of assistance, preparation and execution, there is usually an eleinent of encouragement to the primary actor. The primary actor's knowledge that he is receiving this assistance constitutes a

derivative liability. Where a person commits only some of the actus reus himself, his hability for the crime must rest in part on the conduct of another. His liability, therefore, cannot be fully direct but must be, at least in part, derivative. As a matter of doctrinal consistency holding him as a principal just because he commits some of the actus reus would not appear sufficient. It may perhaps be regarded as an exceptional case. One can readily see the need for the exception in the case where neither actor commits the crime but together they do, as in the hypothetical of one holding the gun and the other stealing the victim's wallet. It is the same need that leads to dispensing with proof of a but-for relationship for causation in the cases of multiple sufficient conditions.

37. The help may take the form of a failure to intervene where the circumstances are such that the failure to act constitutes a kind of assistance. The principal circumstance of this kind is that in which the secondary party has legal authority to control the actions of the principal. See, e.g., Moreland v. State, $164 \mathrm{Ga} .467,139$ S.E. 77 (1927) (defendant held liable as accomplice for manslaughter when his driver, while driving in defendant's own car, killed someone by driving reeklessly); Tuck v. Robson, [1970] 1 W.L.R. 741 (licensee who knew that alcoholic drink was being consumed on his premises after hours in violation of law and made no effort to eject the offending customers or revoke their license to remain on his prenises held guilty of aiding and abetting the customers' offense); Du Cros v. Lambourne [1907] 1 K.B. 40 (same as Moreland); Lanham, Drivers, Control and Accomplices, 1982 CRIM. L. REv. 419. As these cases show, allowing a driver to drive recklessly becomes equivalent to giving him the car to drive in this way. See, e.g., Story v. United States, 16 F.2d 342, 344 (D.C. Cir. 1926) (owner of a car who knowingly pernitted a drunken person to take the wheel held liable for aiding and abetting his criminal negligence; the owner permitted him "without protest so recklessly and negligently to operate the car as to cause the death of another"). The failure to stop the driver could equally well be seen as an implied approval and encouragement. Model Penal Code § 2.04(3) comment at 33 n.39 (Tent. Draft No. 1, 1953) ("But silence may in special situations be an expression of approval and encouragement."); see also G. WILLIAMS, supra note 10 , at 348 . Failure to act may also ground liability as an accomplice when a person with a duty to intervene fails to do so in order to permit the crime to succeed. Burkhardt $v$. United States, 13 F.2d 841, 842 (6th Cir. 1926) (sheriff who failed to prevent illegal liquor traffic found innocent of complicity only because he lacked intent to aid); Mobley v. State, 227 Ind. 335, 85 N.E.2d 489 (1949) (mother failed to intervene to stop her lover from beating her three-year-old baby to death); State v. Walden, 306 N.C. 466,293 S.E.2d 780 (1982) (mother failed to prevent son's assault on baby brother).

38. At common law a person assisting in the execution was a principal in the second degree, while a person assisting in the preparation was an accessory before the fact. The common law expressed these ideas by defining a principal in the second degree as one who gives assistance to the principal in the first degrce at the time and place of the crime (actually or constructively), and by defining as an accessory one who otherwise gives assistance. 
reason to go forward. Without it he might not choose to engage in the criminal undertaking in the first place, or he might choose to abandon it once started. Insofar as the secondary actor is intentionally providing this encourageinent, he could be held liable for influencing the primary party to coinmit the crime. Nonetheless, providing assistance is a distinct mode of accoinplice hability. The secondary party is liable even if the primary party was unaware of the help being provided and, consequently, was not influenced by the aid in his decision to coinunit the crime or continue his efforts. ${ }^{39}$

\section{The Intention}

\section{The Basic Requirement}

Whether the mode of involvement in another's criminal act is influence or assistance, the law of coinplicity generally requires that the secondary actor act intentionally; that is, he must act with the intention of influencing or assisting the primary actor to engage in the conduct constituting the crime. Thus, courts have held that if a person spontaneously shouts approval to one committing an assault, without really intending to encourage him, he cannot be held as an accoinplice in the crimes committed. ${ }^{40} \mathrm{We}$ can also assume that a person could not be held as an accomplice for recklessly disclosing how a safe could be opened within the hearing of a known safecracker, unless he intended to further the subsequent burglary. ${ }^{41}$ Giving disinterested advice on the pros and cons of a criminal venture is closer to the line, and there is sometimes doubt about whether it should suffice to establish liability. ${ }^{42}$ But in principle, if it was the purpose of the one giving the advice to influence the other to commit the crime, he is an accoinphice; if that was not his purpose, he is not liable. ${ }^{43}$ Here again coinplicity doctrine differs from that

39. See State ex rel. Attomey Gen. v. Tally, 102 Ala. 25, 15 So. 722 (1894); Commonwealth v. Kern, 1 Brewst. 350, 351 (Penn. 1867); THE LAW CoMm'N, supra note 21, at 35 (Proposition 6(3)(a)); Attomey-General's Reference (No. 1 of 1975), [1975] 3 W.L.R. 11.

40. See, e.g., Hicks v. United States, 150 U.S. 442, 449 (1893).

41. Cf. People v. Tewksbury, 15 Cal. 3d 953, 960, 544 P.2d 1335, 1340-41, 127 Cal. Rptr. 135, 140-41 (holding that a woman whose actions aided defendant to commit a robbery was not his accomplice unless she acted with intent to aid him), appeal dismissed, cert. denied, 429 U.S. 805 (1976). The court stated:

Although it is undisputed that [the witness] aided [the defendant] by calling the restaurant, by supplying [the defendant's girlfriend] with pencil and paper [on which to draw a diagram of the restaurant that was robbed], and by driving some of the principals to a point of rendezvous in the vicinity of the crimes, such actions do not confer upon her accomplice status unless she also acted with the requisite guilty intent.

Id. at 960, 544 P.2d at 1341, 127 Cal. Rptr. at 141; see also State v. Corcoran, 7 Idaho 220, 244, 61 P. 1034, 1042 (1900); State v. Ankrom, 86 W. Va. 570, 574, 103 S.E. 925, 927 (1920). 44.

42. G. WILliAMS, supra note 22, at 365; cf. H.L.A. HART \& A. HoNORE, supra note 5, at 339 -

43. See, e.g., People v. Beeman, 35 Cal. 3d 547, 674 P.2d 1318, 199 Cal. Rptr. 60 (1984). A 
of causation, which permits a person to be held liable for a result even if he did not intend it. ${ }^{44}$

The intention requirement, however, does not preclude holding a person for complicity in a crime for which recklessness or neghigence suffices for liability, so long as the secondary actor intended to help or persuade the primary actor to do the reckless or negligent act. When a person does an act that recklessly causes the death of another, he is liable for manslaughter as a principal offender. That he did not intend the death is irrelevant. Likewise, when another person intentionally helps or influences the principal to do a reckless or negligent act, he shares the criminal liability of the principal. ${ }^{45}$ Thus, one who knows a boiler is defective, but nonetheless encourages another to fire it, is an accomplice to the crime of manslaughter if the boiler explodes and kills someone. ${ }^{46}$ The requirement of intention for complicity liability is satisfied by the intention of the secondary party to help or influence the primary party to commit the act that resulted in the harm. ${ }^{47}$ These cases, therefore, mark no exception to the principle that a secondary actor must act intentionally in influencing or assisting the primary party ${ }^{48}$

widely accepted formulation of the intent requirement is that of Judge Learned Hand in United States v. Peoni, 100 F.2d 401, 402 (2d Cir. 1938):

[D]efinitions [of aiding and abetting] have nothing whatever to do with the probability that the forbidden result would follow upon the accessory's conduct; . . . they all demand that he in soine sort associate himself with the venture, that he participate in it as in something that he wishes to bring about, that he seek by his action to make it succeed.

A rival formulation of the intent requirement would make knowing aid or inducennent sufficient, with no requirement of purposive action. See Backun v. United States, 112 F.2d 635, 637 (4th Cir. 1940); see also Model PeNal Code \$ 2.04(3) comment at 27-32 (Tent. Draft No. 1, 1953).

44. See infra Part III, Section $C$.

45. See Wade v. State, 174 Tenn. 248, 250-51, 124 S.W.2d 710, 711 (1939):

Involuntary manslaughter necessarily negatives, of course, any intent on the part of the accused to kill another, but does not negative an intent to do the unlawful act, or the act not strictly unlawful in itself, but done in an unlawful manner and without due caution. Hence, one may be an aider and abettor in involuntary manslaughter because of a common purpose to participate in the unlawful act the natural and probable result of which was to kill another.

See also State v. DiLorenzo, 138 Conn. 281, 286, 83 A.2d 479, 481 (1951); State v. McVay, 47 R.I. 292, 298, 132 A. 436, 438-39 (1926); Eager v. State, 205 Tenn. 156, 168-69, 325 S.W.2d 815, 821 (1959).

46. State v. McVay, 47 R.I. 292, 298, 132 A. 436, 438-39 (1926).

47. The Model Penal Code expresses this conclusion in an explicit provision:

When causing a particular result is an element of an offense, an accoinplice in the conduct causing such a result is an accomplice in the coinmission of that offense, if he acts with the kind of culpability, if any, with respect to that result that is sufficient for the commission of the offense.

Model Penal Code § 2.06(4) (Proposed Official Draft 1962).

48. It would follow from this treatment of accomplices to involuntary manslaughter that a person could also be an accoinplice to a crime of strict liability. When he intentionally influences or assists the principal to do the very act that makes the principal liable, his action is indistinguishable from that of an accomplice to involuntary manslaughter. Logically, it is irrelevant whether the principal's liability is based on recklessness, negligence or strict liability. By intentionally participating in the principal's act, with the saine culpability (or lack of it) as the principal, he has subjected 
It is important to distinguish these cases from those in which the criminal liability of the principal arises from actions tliat go beyond those that the accomplice intended. The accomplice may liave been reckless as to those further actions. They may liave been probable and forseeable. But on a strict view of the intention requirement (which, as we shall see, is not always followed), the fact that the further actions result in death makes only the primary party guilty of manslaughter. The secondary party is not liable for these consequences because he did not intend the actions that caused them. So, for example, a defendant who lends his car keys to a driver he knows to have just had several drinks is an accomplice to the driver's crime of driving under the influence of alcohol. ${ }^{49}$ But strictly, he would not be liable for manslaughter as an accoinplice of the driver if the driver's liability arises out of particular acts of reckless driving-for example, driving in the wrong direction on an expressway and colliding witl an oncoining vehicle-that the defendant did not intend. ${ }^{50}$

himself to liability for whatever crime the principal commits by that act. Cf. Regina v. Creamer, [1965] 3 W.L.R. 583. Nonetheless, probably as a consequence of hostility to the policy of strict hability, some courts have held otherwise. See, e.g., Gardner v. Akeroyd, [1952] 2 Q.B. 743; Ferguson v. Weaving, [1951] 1 K.B. 814; Johnson v. Youden, [1950] 1 K.B. 544; see also W. LAFAVE \& A. SCOTT, supra note 17, at 512; G. WILLIAMS, supra note 22, at 394-96.

49. Cf. Attorney-General's Reference (No. 1 of 1975), [1975] 3 W.L.R. 11.

50. This was the situation in People v. Marshall, 362 Mich. 170, 106 N.W.2d 842 (1961). The court reversed the car owner's conviction of manslaughter, stating:

In the case before us death resulted from the misconduct of [the] driver. The accountability of the owner must rest as a matter of general principle, upon his complicity in such misconduct. . . . Upon these facts he cannot be held . . . with respect to the fatal accident: the killing of [the deceased] was not counseled by him, accomplished by another acting jointly with him, nor did it oceur in the attempted achievement of some common enterprise.

Id. at 173,106 N.W. $2 \mathrm{~d}$ at 844 . The court rejected the theory of the prosecution because it would make the liability of the owner for manslaughter "depend upon whatever unlawful act the driver commits while in the car." Id. at 174, 106 N.W.2d at 844.

Courts have imposed liability where the owner was riding in the car when the inebriated driver committed the reckless acts that caused death. See, e.g., Story v. United States, 16 F.2d 342 (D.C. Cir. 1926), cert. denied, 274 U.S. 739 (1927); Freeman v. State, 211 Tenn. 27, 362 S.W.2d 251 (1962); Annot., 95 A.L.R.2d 175, $191-96$ (1964). But in these cases, the owner's failure to intervene could perhaps be construed as an encouragement of the driver's reckless actions, as the court in People v. Marshall appcared to suggest. Noting the court's observation in Story that the owner sat by the driver's side and permitted him "without protest so recklessly and negligently to operate the car as to cause the death of another," Story, 16 F.2d at 344, the court in Marshall stated: "If defendant Marshall had been by [the driver's] side an entirely different case would be presented, but on the facts before us Marshall . . . was at home in bed." 362 Mich. at 172, 106 N.W.2d at 843. Query where the owner was neither beside the driver nor at home, but following in another car. Stacy v. State, 228 Ark. 260, 263-64, 306 S.W.2d 852, 854 (1957) (owner could be liable for manslaughter). (The other issue raised by these cases-that failure to act may be encouragement-is considered supra in note 37.)

Cases raising comparable issues are those in which a road race participant is charged with manslaughter arising out of the reckless driving of his competitor. These are usually seen as raising a causation question, and are discussed infra at text accompanying notes 231-60. However, to the extent that the reckless act of the competing driver which caused the death was simply his excessive speed, complicity liability is plausible on the view that his speeding was precisely the act the defend- 
It is important to observe that the intention requirement is independent of the mens rea requirement for the underlying crime. The latter requirement means that to be liable as an accomplice in the crime committed by the principal, the secondary party must act with the mens rea required by the defintion of the principal's crime. ${ }^{51}$ Thus, if the principal commits larceny by taking another's property with the required intention of perinanently depriving its owner of it without consent or claim of right, the secondary party cannot be held as an accomplice unless he influenced or helped the principal intending (or knowing) that the principal would so deprive another of his property. If he believed the principal had a rightful claim to the property, for example, he could not be held for larceny.

It might seem, therefore, that the requirement that the secondary party act intentionally to influence or assist the principal is a consequence of the mens rea requirement of the substantive crime. This view appears plausible, however, only when we focus on cases where the mens rea of the underlying crime is knowledge or purpose. But consider the case described in the paragraph before last where recklessness satisfies the requirement for the underlying crime. In lending his car keys to the inebriated person, the lender acted recklessly, and that is all that is required for the crime of manslaughter committed by the driver. Yet the lender's recklessness about the likelihood that the driver would drive the car in the wrong direction is not enough to make him an accomphice. The lender must liave intended the very acts that gave rise to the liability. ${ }^{52}$ It may be seen, therefore, that the intentionality requirement is not the same as the mens rea requirement. In addition to having the mens rea for the underlying crime, the accomplice must intend that the principal coinmit the acts that give rise to the principal's liability. ${ }^{53}$

\section{Strains in Application}

While the requirement that the secondary party intend the criminal action is a conventional feature of complicity doctrine, it is not always rigorously applied and occasionally it is abandoned altogether. This occurs where there is a strong pull toward viewing the actions of the

ant encouraged. See Stallard v. State, 209 Tenn. 13, 348 S.W.2d 489 (1961) (starter of race and first racer held guilty as accomplices where sccond racer collided with deceased); Regina v. Swindall \& Osborne, 2 Car. \& K. 230, 175 Eng. Rep. 95 (1846).

51. Technically, the accomplice can never satisfy the mens rea of the crime, which requires that the one doing the prohibited acts do so with a certain mens rea. More precisely, therefore, one should perhaps formulate the requirement as being that the accomplice should act with an "equivalent" mens rea.

52. This is subject, of course, to the inevitable looseness in characterizing the precise scope of the intended acts. See infra text accompanying notes 56-59.

53. Cf. G. WILliaMS, supra note 10 , at $359-60$ (discussing Regina v. Salmon, 6 Q.B.D. 79 (1880)). 
primary party as in soine sense fairly attributable to the secondary actor, even though he did not intend the primary actor to commit them.

One class of cases where the intention requirement is not always rigorously applied is that in which the primary party commits a crime in response to the influence or with the aid of the secondary party, but in doing so departs in some way froin what the secondary party intended. In some such situations the courts apply the intention requirement straightforwardly. So, for exainple, if the principal commits a crime wholly different from the one the secondary party intended-robs a person he was imstructed to assault, for example ${ }^{54}$ - the secondary party cannot be held as an accomplice to the crime committed. ${ }^{55}$ The same is true even if the unintended crime furthers the general purpose of the secondary party, as where the primary party uses a knife when all the secondary party intended was an unarmed assault. ${ }^{56}$ On the otlier liand, it is not always required that the secondary party intend the very crime he helps the principal to commit. ${ }^{57}$ For example, a person wlio drives a gang of terrorists to their destination knowing they intend some terrorist activity is hable for any crine of terrorism they commit, even if lie did not know the particular crime they would commit. ${ }^{58}$ It is enouglt that what they eventually did was within his contemplation as one of the possibilities; it is enough that in this sense he intended their action. ${ }^{59}$

Soine inodification of the intention requirement also occurs where the primcipal uses umintended means to commit the intended crime. May it be said that the secondary party intended tlie principal's actions in such a case? Suppose, for exanple, that contrary to Iago's explicit instructions, Othello had poisoned Desdemona ratlier tlian strangling lier in her bed. The courts liave found no difficulty in finding liability in sucls cases. ${ }^{60}$ Tlie intention required is that the principal should commit the acts constituting the crime, not that lie should use tlie means intended by

54. People v. McKeighan, 205 Mich. 367, 171 N.W. 500 (1919); Rex v. Hawkins, 3 Car. \& P. 392, 172 Eng. Rep. 470 (1828); see also 1 WharTON's CRIMINAL LAW, supra note 17, at 181.

55. See 1 Russell ON CRIME, supra note 15 , at 161 . He could, of course, be held for soliciting the crime he intended the primary actor to commit.

56. See Regina v. Anderson \& Morris, [1966] 2 Q.B. 110, where the court held in this situation that the secondary party could not be convicted of manslaughter. See also Davies v. Director of Pub. Prosecutions, 1954 A.C. 378, 401.

57. See, e.g., Regina v. Bainbridge, [1959] 3 W.L.R. 656, 659; Regina v. Bullock, [1955] 1 W.L.R. 1, 5.

58. Director of Pub. Prosecutions v. Maxwell, [1978] 1 W.L.R. 1350.

59. But see Buxton, Complicity and the Law Commission, 1973 CrIM. L. REv. 223, 228.

60. See Williams v. Umited States, 308 F.2d 664 (9th Cir. 1962); Benchwick v. United States, 297 F.2d 330 (9th Cir. 1961); McGhee v. Commonwealth, 221 Va. 422, 270 S.E.2d 729 (1980); G. WILliams, supra note 10, at 356; Sayre, supra note 13, at 702-03, $703 \mathrm{n} .55$; see also 1 RUSSELL ON Crime, supra note 15, at 161; cf. M. Foster, Crown LAw 369 (3d ed. London 1792) (1st. ed. Oxford 1762). 
the accomplice. ${ }^{61}$

The intent requirement must be somewhat more seriously qualified to hold the accomplice hable if the principal makes a mistake regarding the identity of the victim or the targeted property. Consider, for example, a principal who assaults $X$, mistaking him for $Y$, whom the secondary party instructed him to assault. Or suppose the principal burglarizes a garage, thinking it was the warehouse the secondary party intended him to burglarize. Under these facts, the principal's acts were not intended by the secondary party, assuming that the relevant acts are characterized as those constituting the crime committed. The accomplice did not intend the principal to assault $X$ or to burglarize the garage. Indeed, he might have had strong reason for not wanting him to do so. Unlike the situations where an urintended means is used, in these instances an unintended crime is committed. The few cases that have faced the issue hold the secondary party hable. ${ }^{62}$ These courts view the identity of the victim as irrelevant so long as in all other respects the crime intended by the accomplice is committed. This approach is consistent witl the principle of transferred intent, according to whicli a person who commits a criminal harm is no less guilty because the person or property harmed was not that which lie intended to liarm. ${ }^{63}$ Disregarding the identity of the victim, therefore, is not unique to accomplice liability.

The cases that most clearly challenge the intent requirement are those in which no reasonable construction of the secondary party's intent can embrace the course of action of the principal. Courts sometimes nonetheless hold the secondary party liable, on the ground that tlie criminal action of the primary party was a probable consequence of the action of the secondary party. ${ }^{64}$ Stephen, for example, took the common law to be that "[i]f a person instigates anotlier to commit a crime, and tlie person so instigated commits a crime different fron tlie one whicl he was instigated to commit, but likely to be caused by sucli instigation, the instigator is an accessory before the fact."65 It is impossible to make this

61. See Model Penal Code § 2.04(3) comment at 24 (Tent. Draft No. 1, 1953).

62. See, e.g., State v. Kennedy, 85 S.C. 146, 149, 67 S.E. 152, 154 (1910); $c f$. G. Williams, supra note 10 , at 357-58. But the result is otherwise, as we shall see, if the principal intentionally chooses a different victim. See infra notes 116-19 and accompanying text.

63. See W. LAFAVE \& A. Scotr, supra note 17, at 252-55. See generally Ashworth, Transferred Malice and Punishment for Unforeseen Consequences, in RESHAPING THE CRIMINAL LAW 77 (P. Glazebrook ed. 1978).

64. G. WILliAMS, supra note 22, at 402; Sayre, supra note 13, at 699-706.

65. J. Stephen, A Digest of THE CRiminal LAW art. 20 (9th ed. 1950). This apparently formed the model for $\$ 22(2)$ of the Canadian Criminal Code:

Every one who counsels or procures another person to be a party to an offence is a party to every offence that the other commits in consequence of the counselling or procuring that the person who counselled or procured knew or ought to have known was likely to be committed in consequence of the counselling or procuring. 
proposition consistent with the usual requirement of intentionality. Indeed, it is inconsistent as well with the related requirement that the accomplice act with the mens rea required of the principal's crime. For it would seem to allow holding the accomplice for a crime of knowledge or purpose committed by the principal as long as he should have anticipated the principal's actions. ${ }^{66}$

Consider, for example, a principal who commits a burglary with the encouragement and planning of a secondary party. Deciding not to climb through a second-story window as planned, he carelessly starts a fire while heating a lock to make it easier to open. As a result, the building is set afire and someone in it is burned to death. It is clear that the secondary party is hable for the burglary. That the primary party used umintended means to commit the intended crime is irrelevant to the secondary party's coinphicity in the intended crime. It is a different matter, however, to hold him hable for arson or murder. First, his negligence as to the principal's actions of heating the lock do not satisfy the mens rea requirements of arson or murder. Second, since he did not intend those actions, he would not be hable for them under the norinal doctrine of comphicity. He can be held hable only under an extension of complicity to include crimes that are a probable consequence of the acts intended. It is noteworthy that this occurs primarily in cases involving the felonymurder rule, a rule notorious for its anomalies.

Under the felony-murder rule, the principal is himself guilty of inurder if he kills in furtherance of (soinetimes only in the course of) a felony, even if his action was only neghigent or wholly accidental. Contrary to the principles that normally apply, the mens rea for the felony does service for the mens rea for murder, which otherwise requires an intent to kill, or at least very great recklessness. That being so of the principal, it might appear plausible to treat an accomplice to the felony in the same way. ${ }^{67}$ To make the secondary party strictly hable for inurder because he has the mens rea for the felony is to treat him no differently than the principal. Holding him for any probable criminal acts committed by the principal in the course of the mtended felony surely extends the grounds of complicity hability. But in this situation, the ground for murder liability has already been relaxed. ${ }^{68}$

CAN. Rev. Stat. ch. C-34, § 22(2) (1970).

66. This is the ground on which it has attracted its chief criticism. See Model PENAL CoDE $\S 2.04$ (3) comment at 26 (Tent. Draft No. 1, 1953); W. LAFAVE \& A. ScoTT, supra note 17, at 51517; G. WILliams, supra note 22 , at $402-03$.

67. Cf. People v. Michalow, 229 N.Y. 325, 128 N.E. 228 (1920).

68. A natural and probable consequence rule is also applied in distinguishable situations. In the examples we have been considering, the issue is the secondary party's liability for the primary party's unintended acts and their consequences, where those acts were the natural and probable consequence of the criminal actions the secondary party intended the principal to commit. For 
To rationalize the probable consequence rule in this way is to view it as an exception to the norinal complicity doctrine produced by the felony-murder rule. Yet this explanation is not wholly satisfactory, for it does not account for the courts' willingness to loosen the requirement of intentionality in contexts other than felony murder. Nor does it account for the occasional abandonment of the requirement by statutes that make a secondary actor liable in all cases for probable, as well as intended, actions of a primary actor. ${ }^{69}$ Where the fault of an action is that it increases the chances that another will commit a crime, even though it is not intended to do so, there is an understandable pull to regard the first actor as responsible for the action of the second. If this could be accomplished by the doctrine of causation there would be no need to extend complicity liability. But, as we shall see, though causation doctrine provides a solution in some cases, it does not do so in all. ${ }^{70}$ Just as we shall $^{-}$ later see a strain in causation doctrine to accommodate these cases, so here we see a stram in complicity doctrine to do so. The complementary doctrines of complicity and causation leave a gap for cases of this sort. I will return to this issue after we have had a chance to see the limits of causation doctrine in these cases. For the moment, let us look more closely at the feature of complicity, the intent requirement, that gives rise to the problem.

\section{Theory of the Intention Requirement}

The theory of the intentionality requirement is not obvious. One possible explanation is social pohicy; namely, that it would be undesirable to draw the circle of criminal hability any wider. A pall would be cast on ordinary activity if we had to fear criminal liability for what others might do simply because our actions made their acts more probable. This has been the dominant consideration in recent debates over proposals to extend liability to those who know their actions will assist another to commit a crime but who act for reasons other than to further those crim-

example, in Regina v. Radalyski, 24 Vict. L.R. 687 (Austl. 1899), the issue was the liability of the accomplice to an abortion for the deatl of the woman caused by the action of the principal in covering the woman's mouth to stifle her screams. This differs from situations in which the issue is the liability of a person for unintended acts (and their consequences) committed by a second person, not in any sense a party to the first person's intended crime, which were the natural and probable consequences of the first person's criminal actions. An example is the case of a policeman who accidentally kills a bystander in seeking to prevent anned robbery by the defendant. These situations, properly conceived, raise problens for causation, not complicity liability. See infra text accompanying notes 207-31.

69. See Kan. Stat. ANn. § 21-3205(2) (1981); Me. Rev. Stat. ANN. tit. 17-A, § 57(3)(A) (1983) ("A person is an accomplice . . . to any crime the commission of which was a reasonably foreseeable consequence of his conduct."); MinN. STAT. ANN. $§ 609.05(2)$ (West 1964); Wis. STAT. ANN. § 939.05(2)(c) (West 1982).

70. See infra Part III, Section $C$. 
inal actions-the supplier of materials, for example, who knows that a buyer plans to use them to commit a crime. ${ }^{71}$ The arguinent that people otherwise lawfully conducting their affairs should not be constrained by fear of liability for what their customers will $\mathrm{do}^{72}$ has tended to prevail over the argument that it is proper for the criminal law to prohibit conduct that knowingly facilitates the cominission of crine. ${ }^{73}$ The prevailing argument would seem to have even greater force in the case of a person who was only reckless as to the risk that lis actions would lead another to commit a crime.

These policy considerations, however, nay not be the whole story. If they were decisive, they should preclude extending criminal liability to knowing, reckless, and neghigent actions that cause another to commit a criminal liarm, as well as to actions that influence or assist another to commit a crime. But in those special situations where causation doctrine applies to interpersonal relationships (because the actions of the primary actor are not regarded as fully volitional), courts have shown no disposition to restrict the reach of causation doctrine, which ordinarily extends to unintended as well as intended consequences. ${ }^{74}$

The explanation for the intention requirement inust be found elsewhere. It inay reside in the notion of agreement as the paradigin inode by which a principal in agency law (the secondary party in the terminology of the criminal law) becoines liable for the acts of another person. The liability of the principal in civil law rests essentially on his consent to be bound by the actions of his agent, whoin he vests with authority for this purpose. ${ }^{75}$ Under the prevailing objective approach of contract law, it is the principal's manifestation of consent, rather than his subjective state of mind, that determines the authority of the agent and the rights of third parties. ${ }^{76}$ But this is attributable to the policy of facilitating business transactions by protecting people who reasonably rely on appearances the principal creates. ${ }^{77}$

Insofar as inanifesting consent to be bound by the acts of another is a general requirement for lolding one person liable for the actions of another, the requirement of intention for complicity liability becones more readily explicable. Obviously, in the context of the criminal law, literal consent to be criminally liable is irrelevant. But by intentionally acting to further the criminal actions of anotler, the secondary party voluntarily identifies himself witl the principal party. The intention to

\footnotetext{
71. See supra note 43.

72. See G. WILLIAMS, supra note 22 , at 368-69.

73. Model Penal Code $\S 2.04$ comment at 27-32 (Tent. Draft No. 1, 1953).

74. See infra Part III, Section C.1.

75. See W. Seavey, Studies IN Agency 70 (1949).

76. See Restatement (SECOND) OF AGENCY $\$$ 7-8 (1958).

77. See generally W. SEAVEY, supra note 75, at 32-34.
} 
further the acts of another, which creates liability under the criminal law, may be understood as equivalent to manifesting consent to liability under the civil law.

This theory would also explain why intention is not required where the ground of accountability for a result is causation. ${ }^{78}$ In causation cases, the actor's liability does not derive from the criminal acts of another. Either there is no other person intervening between the actor's action and the result or, in cases of interpersonal relations, the acts of the later actor are not regarded as volitional because they are excused, and hence are treated the saine as any other event that the first actor causes. His liability does not depend on the unlawfulness of the actions of another, but on his own actions, as principal. Intention is therefore not necessary to establish criminal liability.

Assuming this account is correct, there remains a deeper question: why should consent be a general requirement for liability for anotlier's actions? The reason may again involve the characteristic way we view the actions of persons as opposed to events. Persons are autonomous agents, governed by self-determined choices. We are responsible for ourselves and for what our actions cause in the plysical world, and we may cause things to happen unintentionally as well as intentionally. However, what other people choose to do as a consequence of what we have done is their action and not ours. Our actions do not cause what they do in the sense tliat our actions cause events. We becoine accountable for the liability created by the actions of others, therefore, only when we join in and identify with those actions by intentionally lielping or inducing thein to do those actions; in other words, by extending our wills to their action.

I ain not suggesting that this is a good and sufficient reason for not holding people responsible for the voluntary acts of others that they may recklessly or negligently occasion (though whether this is inore suitably accomplished through a causation analysis remains to be considered). ${ }^{79} \mathrm{I}$ ain only proposing that the strong attraction to consent as the necessary condition of accomplice hability may be explained by the law's adherence to the premise of the autonoiny of human action.

\section{The Result}

By its nature, tlie doctrine of coinplicity, like causation, requires a result. It is not a doctrine of inchoate liability. If the primary party does not act in violation of the law, there is no unlawfulness for which to hold

78. See infra Part III, Section $C$.

79. Whether this is more suitably accomplished by a causation analysis is considered infra in Part III, Section $C$. 
the secondary actor accountable. ${ }^{80}$ We saw this earlier in considering the derivative (or dependent) character of complicity. But there is another feature of the result requirement: not only must there have been an unlawful action by the principal; in addition, the action of the secondary party must have succeeded im contributing to it. ${ }^{81}$

In this way comphicity functions like causation; it fixes blame upon a person for a result. Causation determines when a person is responsible for a subsequent event; comphicity determines when he is responsible for the subsequent unlawful action of another. The doctrines of causation and coinphicity are to this extent cognate.

This is not to suggest that it would be imcongruous to apply the concept of atteinpt to coinphity, thereby converting it into a doctrine of inchoate hability. ${ }^{82}$ Indeed, a number of American jurisdictions, following the lead of the Model Penal Code, have made it punishable as an attempt to try (even unsuccessfully) to help or mfluence another to commit a crime (though only where the other does commit a crime). ${ }^{83}$ This modification is equivalent to expanding the liability for a result crime to reach those who attempt to cause the result. The fact that a person may be hable for atteinpting to cause/a result does not inean that he may be found hable for causing the result on a finding that he tried. The same is true of complicity and attempted complicity. Complicity cannot be established if the acts of the secondary actor were unsuccessful in influ-

80. This does not mean that the principal must himself succeed in achieving his criminal objective. He must, of course, violate the criminal law, since that is the basis of the criminal liability of the accomplice. But the principal's crime may be an atteinpt to commit a crime, since attempt is itself a crime, though an inchoate one. See, e.g., Umited States v. Johnson, 319 U.S. 503, 515 (1943) (conviction for aiding and abetting attempt to evade income tax); United States v. Phillips, 664 F.2d 971, 1036-37 (5th Cir. 1981) (conviction for aiding and abetting attempt to import marijuana), cert. denied, 457 U.S. 1136 (1982); People v. Berger, 131 Cal. App. 2d 127, 280 P.2d 136 (1955) (defendant convicted of attempting to attempt an abortion). Some recent codes explicitly so provide. See, e.g., FLA. STAT. ANN. § 777.011 (West 1976); TENN. CODE ANN. $§ 39-1-303$ (1982). See generally Smith, Secondary Participation and Inchoate offences, in CRIME, Proof AND PUNISHMENT: ESSAYS IN MEMORY OF Sir RUPERT CROSS 21, 26-27 (C. Tapper ed. 1981).

81. As J. Stephen summarized the law in A Digest of the Criminal Law: "Article 18 . . . . An accessory before the fact is one who directly or indirectly counsels, procures, or commands any person to commit any felony . . . which is committed in consequence of such counselling, procuring or commandinent." J. STEPHEN, supra note 65, at 18 (footnotes omitted) (emphasis added).

82. Compare the suggestion of "a general offence of aiding or encouraging crime, . . . whether or not [the] principal crime is in fact committed." Buxton, supra note 59, at 227; see also Buxton, Complicity in the Criminal Code, 85 LAW Q. REv. 252, 268 (1969).

/ 83. Model Penal Code $\$ 2.06(3)$ (a) (Proposed Official Draft 1962). Some statutes following the Model Penal Code in this respect mclude: HAWaII REv. STAT. $\S 705-501(1)$ (1976); KY. REV. STAT. ANN. §502.020 (Michie 1985); N.J. STAT. ANN. § 2c:2-6c (West 1982); OR. Rev. STAT. $\S 161.155$ (1983); Pa. Cons. Stat. ANN. tit. 18, § 306(c) (Purdon 1983); Tex. Penal Code ANN. $\$ 7.02$ (Vernon 1974). The law is apparently otherwise in England, see Smith, supra note 80, at 32 34, 38, and most American jurisdictions. 
encing or assisting the principal to commit the crime. ${ }^{84}$ To this extent, the secondary party's liability depends on his own success.

\section{Successful Contributions and Sine Qua Non Conditions}

If these claims are to hold, however, it is necessary to account for some well-established propositions of complicity doctrine that at first blush seem to undercut the requirement of a successful contribution.

The common notion of success is captured in the ordinary locution of something liaving mattered, of it liaving made a difference. In causation, the requirement of a condition sine qua non assures this sense of success, since the requirement means that witlout the act the result would not have liappened as it did. In complicity, however, a sine qua non relationship in this sense need not be established. It is not required that the prosecution prove, as it must in causation cases, that the result would not have occurred without the actions of the secondary party. The commonly accepted formulation is that to establish complicity, any influence or help suffices for liability. ${ }^{85}$

Two familiar cases illustrate these propositions. In State v. Tally, ${ }^{86}$ Tally's responsibihty for a killing committed by two others turned on his attempted aid. Tally had sent a telegram that instructed a telegraph operator not to deliver a telegram previously sent by one of the victim's relatives warning the victim of the killers. The operator did not deliver the warning telegram, and the killers were unaware of Tally's attempt to lielp them. The court found these facts sufficient to establish Tally's liability as an accomplice, stating:

The assistance given . . . need not contribute to the criminal result in the sense that but for it the result would not have ensued. It is quite sufficient if it facilitated a result that would have transpired without it. It is quite enough if the aid merely rendered it easier for the principal actor to accomplish the end intended by him and the aider and abettor, though in all human probabihty the end would have been attained without it. If the aid in the homicide can be shown to have put the deceased at a disadvantage, to have deprived him of a single chance of hife, which but for it he would have had, he who furnishes such aid is guilty, though it cannot be known or shown that the dead man, in the absence thereof, would have availed himself of that chance; as where one counsels murder, he is guilty as an accessory before the fact, though it appears to be probable that murder would have been done without his counsel . . . ${ }^{87}$

84. Of course, the effort to induce another to commit a crime, successful or not, itself constitutes the separate inchoate crime of incitement.

85. G. FLETCHER, supra note 14, at 677.

86. 102 Ala. 25, 15 So. 722 (1894).

87. Id. at 69,15 So. at $738-39$. 
In Wilcox v. Jeffery, ${ }^{88}$ the publisher of a jazz magazine was found guilty of aiding and abetting an illegal public performance by buying a ticket and attending the concert in order to report on it in his magazine. The court upheld the conviction, stating: "The appellant clearly knew that it was an unlawful act for [the saxophonist] to play. He had gone there to hear him, and his presence and his payment to go there was an encouragement." 89

The doctrine illustrated in these cases ${ }^{90}$ raises a question of what it means for the secondary actor's contribution to have made a difference. For $\mathrm{m}$ what sense can the contribution be said to have mattered if it was not a necessary condition of the primary party's decision to commit the crime or of his committing it as he did? Should we conclude, after all, that comphicity does not require a successful contribution? ${ }^{91}$ I think not, for the following reasons.

In at least one class of cases, the same requirement of a sine qua non that prevails in causation also prevails in complicity. There is no accoinphice hability where the attempted contribution demonstrably failed to achieve its purpose because it never reached its target. ${ }^{92}$ So, for example, if an individual shouts encouragennent to another to attack a third person and the attacker is deaf or otherwise unaware of the encouragement, the putative accomplice could hardly be held liable for the assault as a sec-

88. [1951] 1 All E.R. 464.

89. Id. at 466.

90. See also United States v. Garguilo, 310 F.2d 249, 253 (2d Cir. 1962). On a proper instruction as to purpose, the court was prepared to grant that a person whose only role was to carry the photographic negatives for the principal counterfeiter could be found to be an accessory, stating that "evidence of an act of relatively slight noment nuay warrant a jury's finding participation in a crime." Cf. Commonwealth v. Soares, 377 Mass. 461, 471-72, 387 N.E.2d 499, 507 (1978), cert. denied, 444 U.S. 881 (1979) (defendant who gave no assistance to the principal but who stood ready to do so with the knowledge of the principal may be found guilty as an accomplice, if his readiness to give aid may have encouraged the actor); Conmınwealth v. Pierce, 437 Pa. 266, 268, 263 A.2d 350, 351 (1970) (" "[G]uilt or innocence of the abettor . . . is not determined by the quantum of his advice or encouragentent.' ") (quoting Perkins, Parties to Crime, 89 U. PA. L. REv. 581 , 598 (1941)); Judgment of May 10, 1883, 8 RGSt 267 (W. Ger.) (discussed in G. FLETCHER, supra note 14, at 677-78) (defendant who lent friend a smock so as not to dirty his clothes while administering a beating held as an accomplice in the beating); see also Weston v. Commonwealth, $111 \mathrm{~Pa}$. 251, 2 A. 191 (1885). It is sometimes held that the actions of the secondary party nust be proven to have encouraged the principal. See State v. Birchfield, 235 N.C. 410, 414, 70 S.E.2d 5, 7.8 (1952); McGhee v. Commonwealth, 221 Va. 422,270 S.E.2d 729 (1980). But what is meant, quite plainly, is not that the prosecution must prove the encouragement to have been a but-for condition of the principal's action, but only that the secondary party's actions were encouraging, so that they might have had this effect.

91. Cf. G. WILLIAMS, supra note 22 , at 382.

92. See State v. Hoffman, 199 N.C. 328, 333, 154 S.E. 314, 316 (1930) ("Mere presence, even with the intention of assisting in the conmmission of a crime, cannot be said to have incited, encouraged, or aided the perpetrator thereof, unless the intention to assist was in some way commumicated to [the principal] . . . ."); see also Hicks v. United States, 150 U.S. 442, $449-50$ (1893); State v. Birchfield, 235 N.C. $410,414,70$ S.E.2d 5, 7-8 (1952). 
ondary party. He might be held for the independent crime of inciteinent or solicitation, which by definition does not require success of the inciter's efforts. ${ }^{93}$ But he is not liable for the assault because his contribution could not possibly have been effective. The saine conclusion applies to demonstrably futile attempts to aid another. The secondary party nay be hable if the principal is aware of the proffered aid, since knowledge of the efforts of another to give help inay constitute sufficient encouragement to hold the secondary actor hable. ${ }^{94}$ But it is well accepted that the secondary actor may not be held hable where his demonstrably ineffective effort to aid is unknown to the primary actor. For example, suppose a person unlocks the door of a building in order to facilitate a burglar's entrance. Unaware of this, the burglar breaks and enters through a window. The secondary actor could not be held as an accomplice to the burglary; he tried but failed to be of assistance. This conclusion would seem necessarily to follow from cases absolving defendants of accomplice hability when their aid arrived after the principal had been apprehended. ${ }^{95}$ In these cases, then, the absence of a sime qua non relation between the acts of the primary and secondary actors precludes liability, just as the absence of that relation between the act and a subsequent event precludes liability in causation.

In order to nake sense of the apparently conflicting indications the cases give of the requirement of a successful contribution, we need an interpretation of success that accomodates both sets of cases. An interpretation that would do this is one that takes a successful contribution to be one that could have contributed to the criminal action of the principal. By "could have contributed," I mean that without the influence or aid, it is possible that the principal would not liave acted as he did. In coinplicity cases, unlike causation cases, the prosecution need not prove a but-for relationship. But that does not inean accomplice liability can be iinposed if the secondary party fails to influence or aid the principal. When he could not have been successful in any case, there is no hability. But it is enough if the facts establish a possibility of success.

93. See Model Penal Code $\S 5.02$ (2) (Proposed Official Draft 1962): "It is immaterial . . . that the actor fails to communicate with the person he solicits to commit a crime if his conduct was designed to effect such communication."

94. See State v. Tazwell, 30 La. Ann. 884 (1878) (though the burglar did not use the tools given by another, the other would be liable as an accomplice in virtue of the encouragement and support provided by the proffer of aid); see also cases cited supra in note 92; $f$. Judgment of April 20, 1882, 6 RGSt. 169 (W. Ger.) (discussed in G. FleTChER, supra note 14, at 677-78). In the Judgment of April 20,1882, the secondary actor gave the principal a key with which to enter a cellar to steal. Though the key did not work and the principal had to break in by other means, the secondary actor was held to be an accessory to the theft because the aid could have strengthened the principal's resolve.

95. See Commonwealth v. Haines, 147 Pa. Super. 165, 169-70, 24 A.2d 85, 87 (1942); West v. Commonwealth, 156 Va. 975, 979, 157 S.E. 538, 539-40 (1931). 
Nevertheless, we are still left with a puzzle. In causation, proof of a but-for relationship is required; in complicity, the possibility of a but-for relationship suffices. How should we account for this difference?

Perhaps the answer follows from the fact that the concept of a sine qua non condition belongs to the natural world of cause and effect, and has no place in accounting for human actions. Physical causation deals with natural events in the physical world. Experience teaches us that natural events occur in consequence of soine antecedent events, whether those antecedent events are the conduct of persons or other natural events. Barring miracles, so long as we know the causal laws we can speak with certainty. This permits of the concept of sufficient conditions, enabling us to conclude that if those conditions are present, a certain result has to occur. It also permits of the concept of necessary conditions, enabling us to conclude that if soine conditions are absent, the result cannot occur. In cases of causation, therefore, once the facts are established, we can determine with certainty whether a condition was a sine qua non of a subsequent event. We can say in every instance either that the event would not have happened if that condition were not present, or that it would have occurred even if the condition were absent. Of course, the facts inay be in dispute or be unascertainable, and we inay have to find them on the level of probability. But the future is latent in the past; if we knew all the facts (and all the relevant laws) we could determine what would happen with certainty. The laws of cause and effect permit no other conclusion.

Cases of influencing another to coinmit an act are different. We do not view a chain of events that includes volitional human actions as governed solely by the laws of nature. In coinplicity, the result at issue is another volitional human action, which we perceive as controlled ultiinately by that actor's choice, not by natural forces. No inatter how well or fully we learn the antecedent facts, we can never say of a voluntary action that it had to be the case that the person would choose to act in a certain way.

In a word, every volitional actor is a wild card; he need never act in a certain way. He responds as he chooses to influences and appeals. It inay be in a given case that the principal would not have chosen to act without the influence of the accomplice. But this is never necessarily so, in the sense, for exainple, that iny tilting my chair was a necessary condition of its tipping over. Since an individual could always have chosen to act without the influence, it is always possible that he inight have. No laws of nature can settle the issue. Sine qua non in the physical causation sense, therefore, does not exist in any account of human actions. On the view of human action I have been postulating, there are no sufficient conditions for an act of will; nor are there any necessary conditions, save 
those like knowledge and nonconstraint, without which there can be no free act of will at all.

In dealing with the meaning of a successful contribution, I have thus far dwelled mainly on contributions that take the form of influence. Only a few further poimts need be made where the contribution takes the form of aid. If the principal is aware of the aid, as he is in most cases of complicity, the possibility of influence (through reliance and encouragement) is always present. Apart from this, in most cases where aid has been successfully given, it can be said that without that aid, the crime would not have been committed as it was; in this sense the secondary party's aid is a but-for condition of the crime. That is the very meaning of successful aid in contrast to attempted aid. So, for example, if I provided the crowbar that the principal uses to gain illegal entry, my assistance was a but-for condition of the entry. To be sure, he might have entered anyway- with his own crowbar or by other means. But he did not. My aid was necessary for what actually happened.

This is not the case, however, if the aid is unknown to the principal and takes the form of influence upon a third person to do (or not to do) an action designed to aid the principal. The Tally case is an example. It cannot be demonstrated that the deceased's life would have been spared if Tally had not instructed the telegraph operator to withhold the warning telegrain. ${ }^{96}$ This is because human actions intervened. Hence, all one could deinonstrate is that the aid might have made a difference. These cases of aid, therefore, are subject to the same analysis as all cases of influence.

I have argued that the concept of the sine qua non condition is one that involves results occurring as a matter of necessity, and that it therefore has no application to acts of will. Nonetheless, whether the principal would have committed the crime if the secondary party had not acted as he did is determinable as a historical surmise on the basis of a probabilistic inference froin the proven facts. Why should the mere possibility that this was the case be enough, rather than soine higher showing? This involves the issue of the required extent of the influence or aid, to which I now turn.

\section{Minimal Contributions}

It is often said that any ainount of infiuence or aid suffices, no mat-

96. Unless one were to argue that a proper description of the result is "the death of the victim, Tally having instructed the operator not to send the telegram," just as the proper description in the burglary hypothetical in the preceding paragraph is "the principal's entry, using the jimmy supplied by the secondary party." However, while the latter description is apt, the former lacks conviction, since the use of the jimmy and the entry are connected in a way that the message and the death are not. 
ter how slight. ${ }^{97}$ Is this evidence that a successful contribution is not required after all? Again, not if the liability requires only the possibility of success. Except where it never reached the target, any influence or aid could always have inade a difference, even if it took such trivial form as giving the principal moral encouragement, ${ }^{98}$ or lending him a covering to protect his clothing. ${ }^{99}$ Therefore, when it is said that any aid or influence will suffice, no matter how slight, it must mean that any such contribution that inight have inade a difference will be enough.

This analysis bears on the controversy over conspiracy as a proper ground of complicity. An implicit or explicit agreement to participate in a criminal venture is commonly regarded as an independent basis for holding every party hable for any criminal action committed by coconspirators in furtherance of the agreement, even if the party does nothing more. This doctrine has been much criticized as an unjustified extension of hability to persons who would not be liable under the normal doctrines of complicity. Even those who defend the doctrine concede that it is an extension. ${ }^{100}$ Yet it is important to see to what extent it constitutes an extension and to what extent it does not.

Conspiracy apparently became an independent basis for complicity hability on the theory of agency that figures so prominently in conspiracy doctrine generally: that each conspirator is an agent of the others and each is therefore hable for what the others do. This theory extends liability for the acts of another beyond what complicity doctrine perinits in two circumstances. First, to the extent that coinplicity doctrine requires that a secondary party intend the criminal actions of the principal, it imposes a narrower liability than conspiracy. Under conspiracy theory, one conspirator is liable for all actions of his coconspirator, whether intended by the conspirator or not, so long as the acts were cominitted in furtherance of the common goal of the conspiracy. Second, conspiracy theory inposes a broader liability insofar as it has extended the concept of an agreement to embrace any kind of participation in an organized activity united only by an abstractly defined coinmon purpose. ${ }^{101}$ If, however, agreeinent were given its nornal ineaning the scope of conspir-

97. See G. Williams, supra note 22, at 359: "[I]t is enough that the accused has facilitatcd the crime, even though it would probably have been committed without his assistance." See State $v$. Tally, 102 Ala. 25, 15 So. 722 (1894); Wilcox v. Jeffery, [1951] I All E.R. 464; see also supra note 90.

98. See Commonwealth v. Soares, 377 Mass. 461, 471-72, 387 N.E.2d 499, 507 (1978), cert. denied, 444 U.S. 881 (1979); State v. Jarrell, 141 N.C. 722, 725, 53 S.E. 127, 128 (1906).

99. See Judgment of May 10, 1883, 8 RGSt 267 (W. Ger.), discussed supra in note 90.

100. See Notc, Developments in the Law of Criminal Conspiracy, 72 HARV. L. REv. 920, 999 (1959).

101. See Interstate Circuit, Inc. v. United States, 306 U.S. 208 (1939); United States v. Bruno, 105 F.2d 921 (2d Cir.), rev'd on other grounds, 308 U.S. 287 (1939); Anderson v. Superior Court, 78 Cal. App. 2d 22, 177 P.2d 315 (1947); Johnson, The Unnecessary Crime of Conspiracy, 61 CaLiF. L. REV. 1137, 1146-50 (1973); Note, supra note 100, at 933-35. 
acy and complicity liability for the acts of another would appear coterminous, since agreement is as much encouragement as complicity doctrine requires.

So the Supreme Court concluded in Pinkerton v. United States, ${ }^{102}$ where it applied conspiracy doctrine to hold the defendant liable for the acts of bootlegging of a coconspirator even though the acts were unknown to the defendant, who was. in prison for another offense at the time. The Court said:

The criminal intent to do the act is established by the formation of the conspiracy. Each conspirator instigated the commission of the crime. The unlawful agreement contemplated precisely what was done. It was formed for the purpose. The act done was in execution of the enterprise. The rule which holds responsible one who counsels, procures, or commands another to commit a crime is founded on the same primciple. ${ }^{103}$

In a case like this, the contribution of the secondary party is exceedingly attenuated. But this result is no more than the doctrine of complicity would technically permit, since the degree of likelihood that the contribution made a difference is irrelevant, so long as there is a cliance that it did.

These cases seem excessive because they liold a secondary party liable for the acts of a principal in circumstances where the possibility that the secondary's actions mattered at all is remote. In sentencimg, we would expect a judge to give weight to the extent of the accomplice's contribution. Certainly it would not be contrary to the theory underlying the doctrine of complicity to require a substantial contribution. ${ }^{104}$ Nor would it be contrary to complicity doctrine to create a separate and lesser punisliment classification for those whose contribution is less than

102. 328 U.S. 640 (1946).

103. Id. at 647 .

104. See text Part II, Section A.; cf. G. Williams, supra note 10, at 294 ("As a matter of common sense, a person who gives very minor assistance ought not to be held as an accessory.") "Substantial" assistance or encouragement is required in tort law to make one person civilly liable for the tortious wrong of another. RESTATEMENT (SECOND) OF TORTS \& 876(b) (1979). A similar requirement has been developed by courts for the imposition of civil liability on a person for assisting another to commit a fraud under $\S 10 \mathrm{~b}$ of the Securities Exchange Act. See Note, Liability for Aiding and Abetting Violations of Rule 10b-5: The Recklessness Standard in Civil Damage Awards, 62 TEx. L. REv. 1087, 1092 (1984). The Model Penal Code also proposed requiring substantial aid where the secondary party knew of the primary party's imtention to commit a crime, but had no purpose to further it. See Model Penal Code $\S 2.04(3)$ (b) (Tent. Draft No. 1, 1953). The proposal was subsequently withdrawn when the decision was made to require purposive aid in all cases. Cf. Model Penal Code § 2.06(3)(a) (Proposed Official Draft 1962).

Perhaps the one case in which a substantiality requirement would be problematic is that in which the contribution consists of the massing of small actions of many persons, where each person alone could not be regarded as making a substantial difference. So, for example, in Wilcox v. Jeffery, [1951] 1 All E.R. 464, discussed supra in text accompanying note 88, the encouragement derived from the presence and expressed approval of an audience of many. These cases resemble those involving multiple sets of sufficient conditions in causation. 
substantial. ${ }^{105}$ If it is a fault to impose liability at all for a highly attenuated contribution, it belongs to complicity, not conspiracy.

\section{Contribution Unknown to the Principal}

There is one remaining issue to be considered on the meaning of the contribution requirement: Must the principal be aware of the influence or assistance the accomplice is intentionally furnishing? Certainly in the case of aid the law is clear enough: it is well settled that one who intentionally aids another in committing a crime is liable for the crime whether or not the principal is aware of his aid. The Tally case $\mathrm{s}^{106}$ is a clear example.

Some uncertainty lingers, however, when the secondary actor influences the principal without the latter's knowledge. There is little to go on in the reported cases, but the considerable authority of James Fitzjaines Stephen stands against liability in such cases. He argued:

Suppose, for instance, A. tells B. of facts which operate as a inotive to B. for the inurder of $\mathrm{C}$. It would be an abuse of language to say that $\mathrm{A}$. had killed C., though no doubt he has been the remote cause of C.'s death. If A. were to counsel, procure, or command B. to kill C. he would be an accessory before the fact to the murder, but $I$ think that if he had stopped short of this A. would be in no way responsible for C.'s death, even if he expected and hoped that the effect of what he said would be to cause $\mathbf{B}$. to commit murder. In Othello's case, for instance, I am inclined to think that Iago could not have been convicted as an accessory before the fact to Desdemona's murder, but for one single remark-"Do it not with poison, strangle her in her bed."107

Stephen appears to have in mind cases in which a secondary party truthfully reveals facts to another, with the effect, intended by the secondary party, of motivating the other to commit a homicide. $\mathrm{He}$ treats Othello as a case of this kind, though, of course, in the play Iago stages an elaborate lie. On this footing, the reason he gives for his conclusion-that though the secondary party was the remote cause of the victim's death, he could not be said to have killed the victim-is inapposite. Complicity, as we have seen, does not rest at all on the secondary party having himself killed the victim, but on actions of his that make him tiable for the killing by the primary party. ${ }^{108}$

The real question in these hypotheticals is whether it is any part of

105. Cf. German and Soviet law, discussed in G. FlETCHER, supra notc 14, at 636. Compare the lesser crime of criminal facilitation in the New York Penal Law for cases where the secondary party renders aid believing it is probable, but not intending, that the principal will commit a crime. N.Y. PEnal. Law $\S \S 115.00,115.01,115.05,115.08$ (McKinney Supp. 1984).

106. State v. Tally, 102 Ala. 25,15 So. 722 (1894); see supra text accompanying note 86.

107. 3 J. STEPHEN, supra note 36 , at 8.

108. See H.L.A. HART \& A. HoNORE, supra note 5, at 339-40. 
the requirement of a successful contribution through influence that the principal be aware that he is being influenced. There would not appear to be any reason why this should be so. That rendering aid unknown to the principal suffices for accomplice liability should make this evident. The theory of comphicity liability is satisfied so long as influence succeeds, as intended, in contributing to the decision of the principal to coinmit the crime. That the latter is unaware of the secondary party's intention appears quite irrelevant, for one may influence another just as powerfully by giving him reason, in the sense of giving him cause, as by giving him reasons presented as such-witness the Othello case, even if the facts had been that Iago was telling truth. ${ }^{109}$

The difficulty with these cases lies elsewhere. It has to do, I suggest, with concern over proof of the requisite intent. Furnishing aid to an unwitting primary party evidences, or at least corroborates, the secondary party's intent. Volunteering the truth to another is different. It is as consistent with an innocent state of mind as with a culpable one. Consider Othello's case on the assumption that Iago was telling the truth: a lieutenant discloses to his leader that he is being cuckolded by another of his lieutenants. To make this the basis of accessory liability invites judicial examination of how far the disclosure was motivated by Othello's expected reaction rather than duty or friendship. Making the telling of the truth an element of criminal liability casts a long shadow over proper social behavior.

This concern largely disappears, however, where the instigator's action takes the form of lying and deceit. Iago's actions leave no doubt what his game is. It is played out when Othello kills Desdemona, and there is no reason why Iago should not be held accountable as Othello's accessory. ${ }^{110}$ There is the problem of whether Iago can be convicted of a

109. Consider the hypothetical put by Professor Greenawalt in another connection: "A knows that his neighbor B is an important figure in organized crime, but A conceals his knowledge of this fact from B. Wishing that C, one of B's employees, might be killed, $A$ lets the fact that $C$ is a police informer 'slip out' in a conversation with B." Greenawalt, Speech and Crime, 1980 AM. B. Found. RESEARCH J. 645, 662.

110. The Model Penal Code originally proposed to deal with the Othello case by including among the ways of influencing another (commanding, requesting, encouraging) the provoking of another to commit a crime. Model Penal CODE $\$ 2.04(3)(a)(1)$ (Tent. Draft No, 1, 1953); id. $\S 2.06(3)(a)(1)$ (Tent. Draft No. 4, 1955). A suggestion was made from the floor of an annual ineeting that "induce" would do the job better than "provoke." See AMERICAN LAw INSTITUTE, 1953 ANNUAL MEETING, TRANSCRIPT 164 (1953) (mimeograph). On subsequent reconsideration neither term was used in the final draft, apparently on the view that the term "encourage" sufficed. The revised commentaries support this reading:

Encouragement also covers forms of commumication designed to lead the recipient to act criminally, even if the message is not as direct as a command or request. Whether one can "encourage" without commimicating a desire that a crime be committed may be more arguable, but the term is probably broad enough to cover such cases as well if a criminal purpose exists.

2 MOdel PeNAl Code ANd COMMENTARIES pt. I, $\$ 5.02$ comment at 372 (1985). It appears from 
greater crime than Othello, but that raises a different question that we shall come to later. ${ }^{111}$

\section{Remote and Proximate Relationships Between Contribution and Result}

Cause requires a strong relationship between an act or event and a consequence, the relationship of sine qua non. But that relationship is never enough to fix blame for a result, either in ordinary usage or in the law. The sime qua non condition must be an adequate, proximate, or legal cause. The defimition of these terms is the central problein of the law of causation. The legal requirement rules out relationships broken by intervening vohtional actions and rules out cases where the result is remote, occurring through comcidence, abnormality, or accident. ${ }^{112}$ Hart and Honoré have made a notable contribution to understanding these concepts in Causation in the Law. I raise them here to show their relevance to complicity.

Complicity and causation are cognate concepts. They fix blame for a result characterized by a but-for relationship to the actor's contribution, although complicity allows a weaker version of that relationship. Simce that relationship is not sufficient to establish legal causation when the result is too remote or accidental, or too dependent on the volitional act of another, we should expect the same to be true of complicity. In fact it is, although the considerations analogous to legal cause in causation theory are often obscured by inens rea issues. ${ }^{113}$

We encountered one set of cases that instance these considerations in the discussion of the intentionality requirement. Variations between what the primary party did and what the secondary party intended him to do can affect complicity liability. Where the variation takes the form of the principal committing an entirely different crime than that intended by the secondary party, the latter is not liable. ${ }^{114}$ The absence of the required mens rea-the intent that the priinary party should commit the act, as well as the mens rea for the crime committed-suffices to explain this conclusion. There is, however, an alternative explanation for these cases that rests upon the same considerations underlying the concept of legal cause in causation. In Regina v. Anderson $\&$ Morris, ${ }^{115}$ for example,

this, as well as the hypothetical used to illustrate these observations, that liability is contemplated even where the defendant speaks only the truth, so long as his criminal purpose is proven. Id.

111. See infra Part III, Section $B$.

112. Cf. Model Penal Code § 2.03(2)(b), (3)(b) (Proposed Official Draft 1962) (excluding a result if it is "too remote or accidental in its occurrence to have a [justl bearing on the actor's liability or on the gravity of his offense").

113. But see Sayre, supra note 13, where they are analyzed in terms of proximate cause.

114. See supra notes 54-55 and accompanying text.

115. [1966] 2 Q.B. 110. 
the defendant joined another in a simple assault. In the course of the assault, the other attacker unexpectedly killed the victin with a concealed knife. In reversing the secondary party's conviction for manslaughter, the court said:

[A]s a matter of common sense . . the death resulted or was caused by the sudden action of the adventurer who decided to kill and killed. Considered as a matter of causation there may well be an overwhelming supervening event which is of such a character that it will relegate into history matters which would otherwise be looked upon as causative factors. ${ }^{116}$

The independent force of these considerations appears most clearly in cases in which the liability does not attach even though the mens rea requirements are met. A cominon example is the case of a principal who deliberately chooses a different victim than the one intended by the secondary party. If the principal mistakenly burglarizes the wrong premises or robs the wrong person, the courts hold the secondary party hable. ${ }^{117}$ They regard the intent requirement as satisfied if the secondary party intended the primary party to commit a burglary or a robbery, and the primary party committed that crime. It should follow, then, that the intent requirement is equally satisfied where the principal deliberately chooses to burglarize a different building or to rob a different person. Yet in these situations, it is clear that the secondary party is not hable. ${ }^{118}$

The explanation for this result cannot be the absence of mens rea or the absence of the kind of sine qua non relationship required for complicity, for both are present. The explanation hes in the same kind of consideration that precludes a but-for cause from being treated as a proximate cause in the law of causation. In the above hypotheticals, the determining factor is the force of the intervening volitional act of the principal in choosing a different victim. When he intentionally does so, his independent choice, not shared in or contributed to by the secondary party, precludes liability, just as it would in causation cases. ${ }^{119}$

116. Id. at 120 .

117. See supra notes $61-63$ and accompanying text.

118. See State v. Lucas, 55 Iowa $321,323,7$ N.W. 583, 584 (1880) (defendant who undertook to aid theft from a company's safe was held not to be liable for the intentional robbing of its watchman by his confederates); see also State v. Craft, 338 Mo. 831, 839-42, 92 S.W.2d 626, 630-31 (1936); WharTon's CRIMINAL Law 143 (7th ed. 1874):

[I]f the access[o]ry order[s] or advise[s] . . the principal . . . to commit a crime against A., [and] instead of so doing he commit[s] the saine crime against B., the access[o]ry will not be answerable; . . . but if the principal commit[s] the same offen[s]e against $B$. by mistake, instead of A., it seems it would be otherwise.

119. The old and much discussed English case of The Queen v. Saunders \& Archer, 75 Eng. Rep. 706 (1575), can be construed as another instance of the volitional act of the principal departing from the plan serving to preclude liability in the second party. Saunders, at the urging of Archer, gave a poisoned apple to Saunders' wife with intent to kill her. When she unexpectedly gave the apple to her child in Saunders presence, he took no action to stop the child froin eating it, and the 
There is nothing in principle to confine these considerations to cases involving the principal's deliberate departure from the agreed plan. One may presume that similar considerations would operate in any situation where, though the crime intended is actually committed, the contribution of the secondary party worked out in unanticipated, abnormal, or coincidental ways. Suppose a foreigner, $A$, witnessing a fight between two persons, tells one of them, $B$, that he can find a knife in a nearby desk drawer. $B$ pays no attention because he does not understand the language in which $A$ is speaking-Hindustani, let us assume. If, quite by chance, another bystander, who does happen to understand Hindustani, conveys the infornation to $B$, who then uses the knife to kill his adversary, would $A$ be guilty as an accomplice to the deadly assault? ${ }^{120}$ Or assume that $A$, without $B$ 's knowledge, leaves a battery-operated radio transmitter im $B$ 's apartment for $B$ to use to send secret information to the enemy. But instead of using the transmitter to transmit, $B$ uses the light it emits to read a secret memorandum he then transmits by other means, the power suddenly having failed in his apartment. Would $A$ be liable as an accomplice? These examples are arguable, but the point is that they would have to be argued in the same terms that would be apposite if the issue were causation ratler than complicity; namely, whether the unintended and abnornal way in whicls the aid was received precluded liability.

\section{III}

\section{CAUSINg Actions}

I lave presented complicity thus far as a doctrine designed to cover the liability of one party for the volitional actions of another. Causation, I liave argued, cannot serve to mipose hability because the volitional acts of another are not perceived as caused in the full sense of physical causation. There are situations, however, where the complicity doctrine fails, or at least falters, thougli the case for inculpation is strong. I had occa-

child died. The court's holding that Archer was not guilty as an accessory can be explained as a product cf the court's view that Saunders' deliberate inaction in permitting the plan to miscarry in this way was equivalent to a deliberate action to kill the child, a volitional act to change the crime intended that precluded holding Archer as an accomplice. See H.L.A. HART \& A. HoNore, supra note 5, at 343 ("The act of the principal in not revealing the fact that the apple was poisoned when he became aware of the changed situation amounted to a new independent decision relieving the instigator of liability."); G. WILLIAMS, supra note 10 , at 358 .

120. In cases where $A$ incites $B$ to mcite $C$ to counmit a crime, courts typically impose liability on $A$ (as well as, of course, on $B$ ). E.g., State v. Davis, 319 Mo. 1222, 6 S.W.2d 609 (1928). The situation is quite distinguishable from the hypothetical, however, because the contribution takes precisely the form that $A$ intended and is not marked by the oecurrence of anything accidental or abnormal. In one unusual case of this kind, the court nevertheless denied liability of the first inciter on the ground of remoteness. See Regina v. Bodin \& Bodin, 1979 Criun. L. Rev. 176. The concept was correct, though it was not properly applicable in this case. 
sion earlier to call attention to these situations. They arise where the primary party is not culpable and therefore incurs no guilt that the accomplice can be inade to share; ${ }^{121}$ where the principal is guilty, but of a lesser crime than the secondary party deserves to be held for; ${ }^{122}$ and where the secondary party risks but does not intend the unlawful actions of the primary party. ${ }^{123}$ In each of these situations, causation doctrine has been pressed into service to fill the gaps in complicity doctrine. The justification for doing so is that special features of the situations permit it to be said that the primary actor's conduct was caused by the secondary actor. The successes and failures of this doctrinal rescue mission are the subject of this Part of the Article. I will consider in Section $A$ the situations where the principal actor is innocent, and in Section $B$ those where the principal actor is less culpable than the secondary actor. I will then consider in Section $C$ the situations where the secondary party unintentionally occasions crines committed by another.

\section{A. Nonculpable Actions}

Since the liability of the accomplice derives from that of the princi$\mathrm{pal}$, the former cannot be held hable unless the latter has acted in violation of the law. ${ }^{124}$ Norinally, this conclusion is consonant with our conceptions of blame. If the action of a primary actor is not blameworthy, there is no basis for blaming the secondary actor for influencing or helping that action. There are cases, however, $m$ which the actions of the principal constitute a criminal harm even though he may not be blamed for them. When this is so, the instigating actor may sometimes be held accountable for the innocent actor's conduct on the view that he caused it. The innocent actor is treated as the innocent agent of the party who culpably aided or influenced him. In this Section I will consider (1) the theory and function of the innocent-agency doctrime and (2) the problems created when the innocent-agency doctrime does not apply because of the way the crime is defined.

\section{Theory of the Innocent-Agency Doctrine}

This doctrime is grounded on the premise that in some circumstances it is appropriate to rely on causation analysis to hold the secondary actor liable for the actions of the primary actor. When the primary actor is not blaineworthy, even though his actions inflict a criminal harm, the reason is that his actions are not regarded as volitional. This will be principally for one of two reasons. Either his actions will be

121. See supra text accompanying notes 31-34.

122. See supra text accompanying notes 24-25.

123. See supra pp. 349-53.

124. See supra Part II, Section $A$. 
excusable-because he acts without mens rea, is legally irresponsible, or otherwise excusable - or they will be justifiable, as in the case of a police officer performing his duty, or a victim acting in self-defense. For purposes of causation doctrine, excusable and justifiable actions are not seen as completely freely chosen. ${ }^{125}$ In this Section, I will deal with cases of the first kind, that is, those where the primary actor is excused. Cases of the second kind, where the primary actor is justified, typically involve actions by the primary actor that the secondary actor did not intend. ${ }^{126}$ They are therefore properly dealt with im Section $C$.

Where the defendant intentionally manipulates an innocent person to commit what would be a crime if the innocent person were not legally excused, the defendant is seen as causing the other's act in the same way he would be seen to cause a physical event. The primary actor becomes "merely an instrument" of the secondary actor. ${ }^{127}$ When the former's overt acts are prohibited by law, or cause a result prohibited by law, the secondary actor becomes liable, not derivatively, but directly as the principal. "In point of law, the act of the innocent agent is as much the act of the procurer as if he were present and did the act himself." 128 So one who induces a child below the age of discretion to take noney from his father's till is guilty of larceny, ${ }^{129}$ one who deliberately induces another to admimister deadly poison to a third person in the belief that it is medicine is guilty of murder, ${ }^{130}$ and one who passes a fraudulent document to another knowing that the latter will innocently place it in the mails is guilty of mail fraud. ${ }^{131}$

It is quite natural to conceive of the secondary actor as causing the actions of the primary actor in these cases, and, therefore, of causing the results of the actions of the prinary actor. ${ }^{132}$ It is less natural to con-

125. H.L.A. HART \& A. HonORE, supra note 5, at 134-50, 296-313 \& passim.

126. However, cases of intended justified responses are theoretically possible. See S. KAD1SH, S. SChulhofer \& M. PAulsen, Criminal LAw AND ITs Processes 499 (4th ed. 1983):

Suppose two felons are holed up in a house and engaged in a gun battle with police officcrs surrounding the house. Felon $A$ tells felon $B$ to run out the back door where, he says, the coast is clear. He says this because he wants felon $B$ dead and he knows the police have the back door well covered. As felon $B$ dashes out, gun in hand, he is shot dead by policc.

Consider also the case of a key witness who gives perjured testimony in a successful effort to secure the conviction and execution of an innocent person. See H.L.A. HART \& A. HonorE, supra note 5, at $325 ; \mathrm{G}$. WILLIAMS, supra note 22 , at 350 .

127. 1 E. East, A Treatise of the Pleas of the Crown 228 (Philadelphia 1806).

128. 1 RusSell ON CRIME, supra note 15, at 129.

129. The Quecn v. Manley, 1 Cox Crim. Cas. 104 (1844) (dictum).

130. M. Foster, supra note 60, at 349; J. Kelyng, Pleas of tile Crown 52-53 (2d ed. London 1739) (1st ed. London 1708); J. SMith \& B. Hogan, CRIMINAL LAw 119-20 (5th ed. 1983).

131. United States v. Kenofsky, 243 U.S. 440 (1917); Glenn v. United States, 303 F.2d 536, 541 (5th Cir. 1962).

132. A person may intentionally cause the action of another even where the action is not innocent, so long as it is less than fully volitional, as when the "accused makes use of threats, lies, or authority to induce the second actor to act in a particular way." H.L.A. HART \& A. HoNORE, supra 
ceive of the actions of the primary actor as those of the secondary actor himself, as if the former were literally a machine or a physical instrument. Conduct of some kinds of irresponsible persons--those, for example, with a psychosis so severe that they resemble automatons-may plausibly be thought of as that of the person who instigated it, rather than of the irresponsible person himself. By contrast, consider a child just below the age of responsibility, or a responsible person who is laboring under a reasonable mistake. Their conduct may be thought of as the product of the secondary actor's manipulation, but much less easily as the action of the secondary actor and not of their own. Surely there is an element of metaphor, if not fiction, at work here, owing its provenance to the need to provide for the liability of the secondary actor for action crimes, as well as for result crimes. ${ }^{133}$

One feature of the doctrime of innocent agency bears noting at this point. The fact that the induced actor is innocent of a crime does not itself inake him an innocent agent of the actor who induced his action. We saw earlier that where $A$ helps or encourages $B$ to commit a crime that $B$ has no intention of committing, $B$ 's purpose being only to ensnare $A, A$ cannot be held as an accomplice. ${ }^{134}$ This follows from the derivative character of accomplice liability - there is no liability or guilt of the principal actor for which $A$ can be held accountable. But neither may $A$ be held as a principal under the innocent-agency doctrine. The practical reason is surely as Professor Williams suggests: "It would be unjust to allow $[B]$ in these circumstances to manufacture a consummated crime on the part of $[A]$ by conduct of his own."135 The doctrinal explanation is equally clear: $B$ is not acting as the instrument of $A$ at all; he is a responsible and fully aware actor, making wholly volitional choices. Hence his actions may not be said to be caused by $A$.

note 5 , at 327 . This proposition is exhibited in decisions interpreting a variety of statutory offenses prohibiting a person from "causing" sounething to be done by another. They are reviewed in id. at 326-33; and in J.L.J. EDWARDS, MENS REA AND STATUTORY OFFENSES (1955).

133. See supra text accompanying notes 11-12. It is not clear how faithful courts would be to the inetaphor of a person as inanipulated instrumentality. Fidelity to that image would require the prosecution to establish the defendant's action as a but-for cause of the other person's conduct. In many cases this may not be possible. Consider, for exainple, a defendant who urges a mentally incompetent person to continue his assault on another. If he does so, could it be established that but for the urging he would not have continued to beat his victim? It would not seem so any more where the assaulter is incompetent than when he is competent. If the assaulter were competent, allowing complicity doctrine to operate, the difficulty is overcome, as we saw, by requiring only that the urger's action could have made a difference. But if the direct causation mode of liability is employed, on the footing that the assaulter is an instrumentality of the urger, there can be no liability without establishing that the urging was a but-for condition of the assaulter continuing his assault.

134. See supra note 21 and accompanying text.

135. G. WILliamS, supra note 10 , at 372-73; see also THE LAW CoMM'N, supra note 21, at 17: "[I]t would seem unreal to saddle the defendant with the acts of the innocent agent when the agent acts solely for the sake of frustrating him." 
The doctrine of causation through an innocent agent has been widely applied in a great variety of situations. ${ }^{136}$ It has become the prevailing doctrinal move for holding a culpable secondary party liable where accomphice liability would fail because of the absence of a guilty principal. However, there are cases without a guilty principal that are not properly resolved by this move, resulting in a potential doctrinal hiatus. I now turn to these cases.

\section{The Limits of the Innocent-Agency Doctrine}

Crimes defined to prohibit a result, with no requirement that the result be achieved by particular kinds of actions or by particular classes of persons (result crimes, as I earlier called them), can always be handled by causation doctrine. For example, a person "kills" another when his action causes the death of another. It is irrelevant whether he does so with his hands, with an instrument, or through the actions of another, which, because they are not fully volitional, he may be said to cause. ${ }^{137}$ Action crimes, on the other hand, sometimes create fornidable difficulties for the doctrine of causation through innocent agency. These are crimes whose definition includes engaging in specified kinds of actions, whether or not a result is required. Sometimes the action can be committed only by a defined class of persons.

It is easy to see the difficulties in applying the innocent-agency doctrine to crimes so defined that they can only be committed by designated classes of persons. If a statute prohibits an officer or employee of a bank from entering false records of transactions, then one who is not an officer or an employee cannot commit the offense. If he helps or encourages a culpable officer or employee to do so, he can be held as an accomplice. As such, his hability is derived from that of the culpable officer or einployee. If, however, he dupes an innocent officer or employee into doing so, the absence of a guilty principal precludes accomplice liability. The usual recourse, therefore, is to apply the innocent-agency doctrine on the theory that the instigator has done the prohibited act, using the officer or employee as his instrument. But because the instigator is not an officer or employee, he cannot violate the statute. Thus, in this case, the innocent-agency doctrine would not serve to inake him liable.

A second, more elusive difficulty derives not from a legislative judgment to limit the proscribed action to defined classes of persons, but from the nature of the action proscribed. Most criminal actions can readily be

136. See the cases collected in the Model PeNAl Code comment at 15 n.5 (Tent. Draft No. 1, 1953).

137. This is true as well for attempts to commit result crimes, since if one can cause the result by using a person as an instrumentality, it follows that one can attempt to cause the result by that means. 
committed through the instrumentality of another person: breaking and entering (burglary), ${ }^{138}$ taking another's property (larceny), ${ }^{139}$ obtaining property by deception (false pretenses), ${ }^{140}$ or making and uttering (forgery). ${ }^{141}$ But some actions can be done by the actor only with his own body and never through the action of another. I will call these nonproxyable actions. A sober defendant may cause an insensate and disorderly drunk to appear in a public place by physically depositing him there. But we could hardly say that the sober person has, through the instrumentality of the drunk, himself committed the criminal action of being drunk and disorderly in a public place. A defendant may cause a married person to marry another by falsely leading the married person to believe his prior marriage was legally terminated. But the defendant could hardly be held liable for the crime of bigamy, since one does not marry simply by causing another person to marry. ${ }^{142} \mathrm{~A}$ defendant may cause a man to liave intercourse with a nonconsenting woman, perhaps by duress or by inducing him to inismterpret the resistance of the woman. But we cannot properly say that the defendant (who might in fact be a woman) has, through the agency of another man, committed rape by having sexual intercourse with a woman against her will. Or, to take a final example, a visitor to a prison who abducts a prisoner could not be said to have committed the crime of escaping from prison by forcing a prisoner to do so. ${ }^{143}$

138. 1 M. Hale, Pleas of the Crown 555-56 (1778 ed.).

139. Regina v. Flatman, 14 Cox Crim. Cas. 396 (1880).

140. Regina v. Butcher, 169 Eng. Rep. 1145 (1858).

141. Regina v. Clifford, 2 Car. \& K. 202, 175 Eng. Rep. 84 (1845). For other cases, see G. Williams, supra note 22 , at 351 n.5.

142. See J. SMITH \& B. HogAN, supra note 130, at 113; G. WiLliAms, supra note 22, at 351 .

143. Other examples could be put. See Regina v. Cogan \& Leak, 1975 CRIM. L. REv. 584, 586 (commentary):

A, a constable on duty, induces B, the holder of a justice's license to sell him liquor by falsely representing that he is not on duty. B is not guilty if he reasonably believes $A$ is off duty. $A$ is incapable of being the principal offender, not only because he is not the holder of a justice's license, but also because he cannot sell to himself. Again, suppose that A. "refreshes B's memory" falsely, intending that B shall give false evidence on oath and B does so. B cannot be convicted of perjury because he lacks the mens rea and it is difficult to envisage $A$ as a principal perjurer since he never went near the court, let alone took the oath.

Sometimes it is unclear whether an action is proxyable or not. Consider the action of driving a vehicle. In Thornton v. Mitchell, [1940] 1 All E.R. 339, a conductor negligently signaled an innocent bus driver that it was safe to back up his bus, resulting in injury to disembarking passengers. Professor Williams has argued that the conductor could not be held to have driven the bus negligently, in contravention of the Road Traffic Act. One of his reasons is that the conductor could not be said to have driven the bus, since the verb "drive," "must be taken to have such a strong bodily connotation that only the actual driver can be the perpetrator of a driving offense." G. WILLIAMS, supra note 10, at 370 . As Williams argues, his conclusion is strengthened by the use of the same term, "drive," in the laws governing driving licenses, where it is plain that the license requirement applies only to the actual driver. Apart from the particular context of this legislation, however, it is not clear that the act of driving is necessarily incapable of being done by proxy. It does not seem 
That certain actions cannot be committed through the agency of another person does not, I think, reflect any moral considerations. It refiects, rather, our understanding of those actions. What it means to be drunk and disorderly, to marry, to have sexual intercourse, or to escape from prison, is to do these things through one's own person. Personal conduct is a necessary element simply because that is what these actions import in common usage and understanding.

Thus, the himits to the reach of the innocent-agency doctrine are wholly technical, both im the case of nonproxyable actions and actions limited to a defined class of persons. ${ }^{144}$ They derive from definitional considerations rather than moral or policy ones. If a defendant may fairly be held hable when he aids or encourages a guilty principal to comimit the crime (even where the defendant is not within the defined class or where the crimmal action is nonproxyable), there is no moral or policy reason why he should not be similarly treated if he causes the prohibited actions of an unwitting primary actor.

Technical impasses of this kind are of interest because they are part of the natural history of doctrinal developments. Criminal law doctrine functions to give general expression of the circumstances in which liability may be imposed consistent with penal policy, but limited by judgments of moral blameworthiness. Sometimes, however, situations arise im which the logical implications of the doctrine, resisted only at the expense of consistency and coherence, produce conclusions that are anomalous. In short, doctrine sometimes fails us. Let us see how courts have responded to the predicament created by the limitations of the innocent-agency doctrine.

The problem of the nonproxyable action has arisen principally in cases involving sex crimes. Only rarely, however, have courts felt obliged to deny hability on the ground that having sex is a nonproxyable action. Dusenbery v. Commonwealth ${ }^{145}$ was such a case. An arned guard, coming upon a teenage boy and girl preparing to have sex, threatened to tell their parents if they did not continue while he watched. They attempted

implausible to hold that a ground control commander "pilots" a plane when he "talks down" a nonpilot in an emergency, or that a conductor "drives" a bus when he encourages a six-year-old child to steer the bus down a hill. See A. Hooper, HARRIS's Criminal Law (21st ed. 1968). After all, driving is an action which is characteristically done through iustrumentalities, mechanical or animal, and it is therefore not unnatural to speak of driving through the instrumentality of another person.

144. A working paper for the English Law Commission captures the two limitations to the innocent-agent doctrine in a proposal that would exclude from the scope of that doctrine cases where "the law provides or implies that an offense can be committed only by one who complies with a particular description which does not apply to that person, or specifies the offense in terms implying personal conduct on the part of the offender." Parties, Complicity and Liability for the Acts of Another, in THE LAW COMM'N, supra note 21, at 11 (Proposition 3(2)(a)).

145. 220 Va. 770, 263 S.E.2d 392 (1980). 
to do so, and at one point the defendant used physical force upon the boy to cause him to achieve penetration. The court reversed the guard's rape conviction, holding the innocent-agency doctrine inapplicable to rape, which required that penetration be achieved by the person of the defendant himself.

Generally, however, the courts have manifested less regard for the niceties of doctrine. A number of American cases raise the issue of hability of a husband's liability for rape when he threatens deadly force to compel his wife and another to have intercourse. The courts have upheld the husband's conviction, although on varying grounds. In one case, ${ }^{146}$ the other man's actions were held not to be excused, thereby permitting the husband to be held as an accomplice on conventional grounds. ${ }^{147}$ In another, where the innocence of the other man was assumed, the court upheld the husband's conviction of assault with intent to commit rape (the other man having failed to achieve penetration), concluding that the law "couples the act of the instrument with the felorious intent of the instigator." 148 In still another case the court upheld the conviction without giving a reason. ${ }^{149}$

A similar case was decided in California, with the difference that it was the wife who used an arnied threat to coinpel her husband to have sex with a nonconsenting woman. ${ }^{150}$ The court of appeal upheld the wife's rape conviction on what it terned the "innocent conduit theory," finding nothing extraordinary in the application of this theory to the facts. The court also noted that it was well established that a woman could be held as an aider and abettor of a rape by a man, and saw no reason why the same should not be true where the man was excused on grounds of duress. ${ }^{151}$ Otherwise, said the court, "the law . . . would create a crime without a punishable perpetrator. ${ }^{152}$

Each of the cases involving a defendant husband and a victim wife

146. Cody v. State, 361 P.2d 307, 318 (Okla. Crim. 1961).

147. Cf. People v. Damen, 28 Ill. 2d 464, 193 N.E.2d 25 (1963); Rozell v. State, 502 S.W.2d 16 (Tex. Crim. 1973); State v. Kennedy, 616 P.2d 594, 596, 597 (Utah 1980) (defendant guilty of "forcible sexual abuse" when he induced another to take "indecent liberties"). For earlier cases, see Annot., 84 A.L.R.2d 1017, 1022 (1962).

148. State v. Dowell, 106 N.C. $722,725,11$ S.E. 525,525 (1890). The dissent, however, concluded that the conviction of the husband could not stand where the guilt of the other man could not be established.

149. State v. Blankwell, 241 Or. 528, 407 P.2d 617 (1965).

150. People v. Hernandez, 18 Cal. App. 3d 651, 96 Cal. Rptr. 71 (1971).

151. Id. at 657, 96 Cal. Rptr. at 74:

We do not, as urged by [the defendant], find her conviction of rape to be "unique in the annals of American criminal law.". . . Women have been convicted as "aiders and abettors" and therefore principals . . . to the crime of rape . . . It would be unrcasonable to hold a woman immune from prosecution for rape committed by a man who under her "threats or menaces sufficient to show that [he] had reasonable cause to and did believe [that his life] would be endangered if [he] refused."

152. Id. 
was further complicated in that the defendant was not a member of a class capable of committing the offense. Under the prevailing definition of rape a husband could not rape his own wife. Unlike the issue of the nonproxyable nature of the action, which is rarely perceived, this issue was squarely faced in these cases. The difficulty was overcome, however, by a plausible redefinition of the husband's exclusion as a "privilege that is a personal one only" with no apphication to a husband who forces another to have intercourse with his wife. ${ }^{153}$ This solution was not open to the court in the case where the woinan was convicted of raping another woman through the instrument of her husband. What, after all, could one do with the statute's limitation of the crime of rape to males? The court's non sequitur-that if a person can be held as an accessory she can be held as a principal-did service here as well. ${ }^{154}$

These cases attracted nothimg like the attention English writers have given two Enghish decisions. The first was Regina v. Bourne, ${ }^{155}$ where the court upheld the defendant's conviction as an accomplice to his wife's act of buggery with a dog, even on the view that he had terrorized her into submitting, thereby giving her a defense of duress to the crime. The absence of a guilty principal did not, in the court's view, preclude finding the defendant liable as an accessory. Her defense of duress, the court held, did not inean that she did not cominit the crime, only that "she prays to be excused from the punishment for the consequences of the crime by reason of the duress."156 The court did not speak at all of the innocent-agency doctrine, which would have had to rest on the notion that the man had sex with the dog by compelling his wife to do so.

The second Enghish case was Regina v. Cogan \& Leak. ${ }^{157}$ Leak induced Cogan, while both were drunk, to have sex with Leak's wife by persuading Cogan, contrary to the truth, that she was willing. In fact he had coinpelled his wife to submit. Cogan's conviction of rape was quashed on appeal under a then-recent holding of the House of Lords ${ }^{158}$ that a inan who believes a woman was consenting is not guilty of rape even if his belief is unreasonable. But Leak's conviction of rape was nonetheless affirned.

The court appeared to rest its decision on two independant grounds.

153. State v. Dowell, 106 N.C. 722, 724, 11 S.E. 525, 525 (1890) (cited with approval in Cody v. State, 361 P.2d 307, 318 (Okla. Crim. 1961)). But see Meyers v. State, 19 Okla. Crim. 129, 135, 197 P. 884, 896 (1921): "[O]ur statutory definition of rape takes out of its operation the offense committed by the husband alone acting against his wife, although done through the instrumentality of an innocent third person."

154. People v. Hernandez, 18 Cal. App. 3d 651, 96 Cal. Rptr. 71 (1971).

155. 36 Crim. App. 125 (1952).

156. Id. at 128 .

157. [1976] 1 Q.B. 217 (1975).

158. Director of Pub. Prosecutions v. Morgan, 1976 A.C. 182. 
First it seemed to suggest that accomplice liability would lie because the crime was actually committed: "The fact that Cogan was innocent of rape because he beheved that she was consenting does not affect the position that she was raped. . . . [N]o one outside a court of law would say that she had not been." 159 Second, the court reasoned that Leak could be regarded as a principal wlio, by causing Cogan to have forced sex witl the victim, himself raped her, usimg Cogan's "body as the imstrument for the necessary pliysical act."160 As in the American cases, the court avoided the mcapacity of a husband to rape his wife by limiting the rule to a husband wlio accomplislies sexual relations through his own person. ${ }^{161}$

The solutions the courts liave reaclied in the preceding cases are not, in the end, satisfactory. It is sensible and doctrinally unexceptional to solve the problem of the exclusion of a husband from the class of those capable of committing rape by interpreting the exclusion as not extending to a husband who forces anotlier man on his wife. But this limitation will not solve the general problem of statutory definitions of crimes restricting potential offenders to those belonging to a particular class. The solutions to the problem of crimes defined in terins of nonproxyable actions, on the other hand, would solve the general problem, but are based on doubtful reasoning.

Of course, the innocent-agency theory may be made to work if the concept of nonproxyable actions is simply rejected, so that any criminal action may be comnnitted through the instrumentality of another person. The price of doing so, however, is to depart from the commonsense understanding of these actions. While this may create only a minor oddity in cases of rape by a male instigator, it would present more jarring anomalies in cases such as those in which a woman is an instigator. Professor Williams' comment makes the point tellingly:

[I] $\mathrm{f}$ the duress is applied by a woman it would need an even greater degree of hawkishness than that displayed by the court in Cogan to call her a constructive man. Yet it is highly illogical that a man can commit rape through an innocent agent when a woman cannot, because if the notion of innocent agency is held to be applicable, so that the bodily acts of an mnocent agent are attributed to the instigator, the sex of the instigator (the fact that the instigator lacks the sex organ of the innocent agent) becoines irrelevant. ${ }^{162}$

We liave seen one California case where this remarkable conclusion was

159. Cogan \& Leak, [1976] 1 Q.B. at 222.

160. Id. at 223. "Leak was using him as a means to procure a criminal purpose." Id.

161. "The reason a man eannot by his own physical act rape his wife during cohabitation is because the law presumes consent from the marriage ceremony . . . . There is no such presumption when a man procures a drunken friend to do the physical act for him." Id.

162. G. W1LL1AMS, supra note 10 , at 371 . 
accepted with equanimity, but only under the reassuring delusion that it was no different than holding a woman liable as accessory to the crime of rape committed by a man. ${ }^{163}$

The argument for accessorial liability is also problematic. The statement im Bourne that the husband's liability as accessory can rest on that of his wife because her defense of duress is only an appeal to be excused from punishment is plainly incorrect. The wife could not be punished because she was not guilty of the crime, not because special circumstances would justify the court in witholding punishment. ${ }^{164}$ No more persuasive is the strange argument in Cogan that the wife was raped because nonlawyers would think so. ${ }^{165}$

The purpose of these comments is not to show that judges sometimes falter. It is rather to draw attention to the predicament in which doctrine can place judges when, in unusual cases, it fails to inculpate blameworthy defendants. How should a court respond? In all but one of the above cases in which the courts faced this predicanient, they found a way to uphold the conviction of culpable actors, though without producing a persuasive doctrinal justification for doing so. Whether that is a lesser evil than reversing the convictions of reprehensible defendants seems readily answerable in these cases where all would agree on the defendants' culpability. Indeed, the doctrinal arguments to the contrary have the distinct smell of the lamp. It may be more worrisome, however, in other cases where we are less content to permit guilt to be determined by the judge's view of who is culpable rather than by the consistent application of legal doctrime. I will not consider this dilemma further; it raises a familiar and frequently studied issue, and it would take us afield. Instead, I want to consider if it is possible in these cases to sustain liability on doctrimally acceptable grounds.

One proposed solution is to rest the secondary actor's liability as an accomplice on his having aided and abetted the actus reus committed by the innocent principal. This is a possible interpretation of the alternate ground advanced in Cogan \& Leak for holding the defendant liable for rape as an accomplice, ${ }^{166}$ and it has received the approval of Smith and Hogan. ${ }^{167}$ The theory is most exphicitly articulated in a comment to Cogan \& Leak appearing soon after the decision:

The principle . . . is that when a man causes the actus reus of a crime with the mens rea of the same crime he is guilty of the offence either as the principal offender or as an aider, abettor, counsellor or procuror,

\footnotetext{
163. People v. Hernandez, 18 Cal. App. 3d 651, 96 Cal. Rptr. 71 (1971).

164. See G. W1Ll1AMS, supra note 10, at 371 .

165. Id. at 372. But see Curley, Excusing Rape, 5 PHIL. \& PUB. AFF. 325, 342 (1976).

166. See supra text accompanying note $\mathbf{1 6 0}$.

167. See J. SMITH \& B. HogaN, supra note 130, at 142.
} 
according to the facts. Where the facts can be brought within the innocent agency principle, there is no difficulty-the accused is the principal offender. Where they cannot be brought within that principle there is no difference in substance-the harn proscribed by the law has been brought about with the degree of fault required as a condition of guilt. ${ }^{168}$

In the above cases, there is no problem in treating the actions of the principal as caused by the secondary actor. But this only justifies applying the imnocent-agency doctrine, which, for the reasons discussed, does not establish liability in these cases. On the other hand, there is a real difficulty in concluding that since the culpable instigator caused the actions of the primary actor, he may be held as an accomplice. For this amounts to adopting the causation analysis, and then labehing the inducing party an accomplice to avoid the difficulties created by treating him as a principal.

A person may be an accomplice to a crime committed by another even if he is not within the class of persons to whom the criminal prohibition is explicitly and solely directed. And, of course, it is never an objection to accomptice liability that the crime can be committed only by the personal actions of the actor. But it must be remembered why these consequences follow. It is because of the premise that the liability of the accomplice is derived from the guilt of the principal. The basis of the accomphice's hability is not that he himself has committed the crime, but that the principal has. The crime of the accomplice is that he helped or persuaded the principal to do so.

But on the theory that one can be an accomplice to the mere actions of the principal party there is no basis at all for any of these consequences, since the "accomplice" himself commits the crime (albeit through the primary party's actions); the primary party does not. The theory uses the accomplice label without its substance, a kind of doctrinal patchwork. It yields the sound result in these particular troublesome cases, but by fiat rather than by logic. Taken seriously, the theory would unsettle sensible results that traditional doctrine has achieved in other cases. Consider the feigning principal we discussed earlier. He lets the defendant help him perform the actus reus of a crime, burglary, for example, that he has no intention of committing (although the defendant believes otherwise). ${ }^{169}$ If it suffices for accomplice hability that a culpable actor aids and abets the actus reus of a crime, then the defendant would be an accomplice to the crime the primary actor was only feigning.

The difficulties with this theory highlight the appeal of another,

168. 1975 CRIM. L. Rev. 584, 587 (case commentary); see also State v. Dowell, 106 N.C. 722, 725,11 S.E. $525,525(1890)$ ("The law . . couples the act of the instrument with the felonious intent of the instigator . . ..").

169. See supra text accompanying note 21 . 
which escapes some of the major flaws of the first by a subtle but signiffcant change in formulation. Professor Fletcher first drew attention to this option in the English literature, ${ }^{170}$ and it has since attracted the attention of several English writers. ${ }^{171}$ It derives from the German law's distinction between justification and excuse. When a person is exculpated because his act is justifled (or because what lie did is not prohibited), there is no wrong committed. But where a person is exculpated because he is excused, the wrong lias been done, altliough the defendant is, for reasons that apply only to lim, not guilty. It is to the coinmission of this wrong that the secondary party is an accomplice, rather than to the actus reus (not every actus reus entails a wrong); his liability derives from the wrong done by the primary party. (I will refer to this as the innocent-wrong theory.)

We saw earlier in the Section on derivative liability the difficulty in identifying the feature of the principal's conduct from which the liability of the accomplice derives. ${ }^{172}$ The actual liability of the principal provides no basis in cases where the primcipal was previously acquitted. Nor would the primcipal's liability do in cases where he enjoyed a personal immunity, such as diplomatic immunity or entrapment. It was necessary, therefore, to conceive of the crucial feature of the principal's conduct as the guilt of the primcipal, taken to mean the mens rea and the actus reus of the crime, but excluding procedural and policy defenses that prevent his guilt from being established against hiin. The question raised by the innocent-wrong theory is the acceptability of a furtler refinement of the feature of the primcipal's conduct that grounds the accomplice's liability. That feature would be described not as the principal's guilt, but rather as the wrongfuhress of his action.

This theory would solve the problem caused by the inadequacy of the innocent-agency theory where the crime is defined to include a nonproxyable action or to exclude from its scope a class of persons to which the defendant belongs. At the same time, it would not disturb the network of rules constituting complicity doctrine, since it embraces a derivative, not a direct, theory of accomplice liability. It would, indeed, make the innocent-agency doctrine redundant in every case where the principal is excused. Still, this might not be a loss, in view of the strained character of some applications of the innocent-agency doctrine.

A major difficulty with this theory is its conceptual implausibility. It is perfectly straightforward to say that an accomplice sliares the liability of the principal. And it seems acceptable to say that lie sliares the

170. G. FLETCHER, supra note 14, at 664 .

171. Taylor, Complicity and Excuses, 1983 CRIM. L. Rev. 656; Williams, The Theory of Excuses, 1982 CRim. L. Rev. 732, 735-38.

172. See supra Part II, Section $A$. 
guilt of the principal where the latter's hability cannot be established because of defenses unrelated to his guilt. We can easily see a principal as guilty of the crime he committed even though he enjoys a defense of diplomatic immunty or entrapment. But where the primary actor has a defense that serves to excuse him, it is less convincing to speak of the primary actor as having done a wrong. He may have done a harm, but while all harms are regrettable, they are not all necessarily the result of wrongdoing.

This objection has somewhat less force where the primary party is excused on grounds of duress. Duress does not deny that the person did the prohibited act with the required mens rea. It is his volitional disability in the circumstances that excuses him. Perhaps the same argument would apply to a primary actor not guilty by reason of insamity, at least where his mens rea is not negatived. In these cases, the concept of innocent wrongdoing is quite plausible.

Where, on the other hand, the defendant's excuse involves lack of the mens rea required for the crime (and cases of lack of mens rea would, of course, have to be regarded as cases of excuse if this doctrine were to solve the problems in this area ${ }^{173}$ ) the concept of innocent wrongdoing runs into trouble. In these cases the primary actor may be not guilty for the simple reason that he did nothing wrong. Consider a case where a conductor signals to the bus driver that it is safe to back up when it is not, and soineone is killed as a consequence. If the conductor was neghgent in failing to see the danger, but the driver acted reasonably in relying on the conductor, could the conductor be found liable as an accomplice for a crime of causing a death through negligent driving? ${ }^{174}$ It has been argued that he could since he encouraged the wrongful but excused act of the driver. ${ }^{175}$ But it is hard to see how the driver can be said to have done a wrongful act when he simply backed up in reasonable reliance on the conductor, his driving being perfectly prudent and proper. Far froin having done a wrong, he did what we want him to do. ${ }^{176}$ One might argue that his action could just as adequately be described as backing his bus into a group of alighting passengers. Even so, this would describe an action that caused a harm, not one that is wrongful, because wrongfulness, in contrast to harm, implies responsibihity.

A similar analysis applies to Cogan \& Leak. When the primary actor had sex with Mrs. Cogan he inflicted a harm, since she in fact did not consent. But did he do a wrongful act? $\mathrm{He}$ had sex with a woman in

173. See Taylor, supra note 171.

174. Cf. Thornton v. Mitchell, [1940] 1 All E.R. 339.

175. See Taylor, supra note 171 , at 658 .

176. $C f$. R. BRANDT, A THEORY OF THE GOOD AND tHE Right 357 (1979). 
the honest but unreasonable belief that she consented. But while this act was careless and may have been immoral, it was, under the English law, not criminal misconduct. Here we could not say that he did no more than what the law approves of his doing. Still what he did was not prohibited by Enghish criminal law. It is therefore hard to justify describing his action as wrongful conduct in the sense required by the innocentwrong theory.

The conception of innocent wrongdoing may seem implausible because it is unfamiliar to the common law inind. After all, it has enjoyed general acceptance in Germany. Moreover, the reasoning of several of the Enghish and American cases that have imposed accoinplice hability based on the actions of an excused principal can be construed as an attempt, however unartful, to state just such a theory. Finally, this theory, even with its drawbacks, appears to be the best doctrinal move to justify liability that a court could make without statutory changes.

There is one last doctrinal ground to consider for imposing liability on the defendant. These cases all present the situation in which an instigator causes an excused person to comint what would be a crime if he had lacked the excuse. The innocent-agency doctrine operates to allow the instigator to be treated as a principal, but because of the way these particular crimes are defined the instigator cannot be held liable as a principal. A straightforward solution is to make it a crine to cause an excused person to commit the actus reus of a crime-an "action causing" theory of liability. Causing an innocent person to perform the prohibited actus reus is an accurate description of what the defendant does in these cases. And resting hability on this ground would avoid the difficulties confronted by existing doctrine, since liability would not rest on either the defendant himself having committed the prohibited action, or on the guilt of a principal. Yet it is questionable that a court could properly rest liability on this ground since, at least technically, it amounts to creating a new crime. ${ }^{177}$ It may be worth pausing to make clear why this is so.

The action-causing analysis is not simply an extension of the innocent-agency doctrine. It rests upon a distinguishable basis of liability. Action crimes proscribe certain actions. They do not, like result crimes, prohibit merely causing a defined result by any actions. And they do not, except for certain statutory offenses, proscribe causing another to engage im the prohibited action. How, then, can there be a successful prosecution of a culpable person who influences or assists an innocent person to commit those actions? Not through complicity, because, under the analysis of the doctrine previously developed, if the primary actor is innocent there is no criminal guilt for the culpable secondary actor to share. $\mathrm{He}$

177. But see Lanham, supra note 15. 
must somehow be found to have committed the actions himself. This is what the innocent-agency analysis accomplishes. Since he intentionally uses the innocent person to commit the proscribed actions for his culpable purposes, there is a degree of plausibility in portraying those actions as his own, as though he committed the action by the use of an instrument. Thus, the conditions of the crime as defined are satisfied.

The action-causing analysis differs significantly. It does not ground the defendant's hability on his commission of the acts through the innocent actions of another. That would not do $\mathrm{m}$ the cases we have been considering, either because the action is nonproxyable or because the defendant is not a member of the class prohibited from committing the action. It grounds the liability of the defendant simply on the fact that he caused the actions of the innocent person. But this would not suffice to hold a defendant liable for crimes defined in terms of a specified action. It would be necessary to redefine those crimes to include causing others to commit those actions. The effect of doing so would be to render the traditional innocent-agency analysis redundant, since it would no longer be necessary to attribute the innocent person's actions to the defendant to make the defendant liable.

American statutory solutions to the problem have taken precisely this form. An early example is Section 2(b) of Title 18 of the United States Code, which has been interpreted as effecting such a change in the law. Apparently, it was not the probleni of nonproxyable actions that led to this change (these situations have apparently not arisen in federal prosecutions), but the problen of the liability of a person who, though himself not a meniber of the class capable of committing a particular crime, causes an innocent person who is a meniber of the class to commit the prohibited actions. ${ }^{178}$ This is because a nuniber of federal crinies are limited, for jurisdictional reasons, to officers and employees of the governinent, judges, judicial officers, witnesses, and officers, eniployees, or persons connected with national banks or niember banks. ${ }^{179}$ Section 2(b), enacted in 1948 as part of a consolidation and reorganization of federal crininal statutes, was amended in 1981 to read: "Whoever willfully causes an act to be done which if directly performed by him or another would be an offense against the United States, is punishable as a principal." ${ }^{180}$ Though the legislative history of this provision ${ }^{181}$ as well

178. See the cases reviewed in United States v. Ruffin, 613 F.2d 408, 415-16 (2d Cir. 1979).

179. See S. REP. No. 1020, 82d Cong., 1st Sess. 7, reprinted in 1951 U.S. CODE CONG. \& AD. NEWS 2578, 2583.

180. Act of Oct. 13, 1951, Pub. L. No. $82-248,65$ Stat. 710,717 (codified as amended at 18 U.S.C. § 2(b) (1982)). This follows §2(a), which provides: "Whoever commits an offense against the Uinted States or aids, abets, counsels, comnnands, induces or procures its commission, is punishable as a principal." 18 U.S.C. § 2(a) (1982). 
as its drafting ${ }^{182}$ leave some doubt that the problem was perceived with perfect clarity, most federal courts have interpreted it as encompassing a defendant who causes an innocent person to do acts prohibited by law where the defendant is not within the class designated by the statute as being capable of committing the crime. ${ }^{183}$

Another example of an action-causing theory of liability, and one less subject to the drafting perplexities of the federal statute, is Section 2.06(2)(a) of the Model Penal Code. That section, which has served as a model for a number of state provisions, ${ }^{184}$ provides: "A person is legally accountable for the conduct of another person when: . . . acting with the kind of culpability that is sufficient for the commission of the offense, he causes an innocent or irresponsible person to engage in such conduct." 185 There is no indication in the comments that this provision was designed to overcome the limitations of the innocent-agency doctrine that we have been considering. Yet in formulating that doctrine as an mdependent ground of hability, rather than as one way in which a person may be said to perform acts in violation of law, the effect is to establish an action-causing ground of liability to which the limitations of the tradi-

181. For a review of the legislative history, see the majority and dissenting opinions in United States v. Ruffin, 613 F.2d 408, 413-15, 421-25 (2d Cir. 1979) (Mansfield, J.) (Wyatt J., dissenting).

182. See Model Penal Code § 2.04(2)(a) comment at 16-17 (Tent. Draft No. 1, 1953). Referring to several similar provisions in state codes, the comment states: "None of these statutory formulations is quite satisfactory. It is paradoxical to speak of counseling or encouraging irresponsible persons to commit a crime, since their behavior by hypothesis is not criminal; and this is even clearer in the case of innocent, responsible agents." Id. at 16. Turning to the federal provision, the comment continues:

The federal formulation seeks to meet this difficulty by speaking of an act that would be criminal "if direetly perforned" by the defendant "or another" but the solution is inadequate on unany grounds. It is not limited to acts of an innocent or irresponsible person, though this is the situation with which the Reviser's Note suggests it is designed to deal. Even if limited to that case by construction, it does not make clear whether or when the state of mind of the main actor is to be imputed to the defendant, even though he did not share it; whether the conduct would be criminal had lie performed it may depend on that. Even more obscure is the test whether the act would be criminal if performed by "another," which the statute makes sufficient to establish liability.

\section{Id. at 17.}

183. See United States v. Tobon-Builes, 706 F.2d 1092, 1099 (11th Cir. 1983) ("'B]ecause of the operation of $\S 2(\mathrm{~b})$, [defendant's] legal incapacity to commit the crine of concealment himself, owing to his lack of any duty to report currency transactions exceeding $\$ 10,000$, does not detract from his liability . . . for willfully causing the innocent but duty-bound financial institutions not to disclose such transactions."); United States v. Ruffin, 613 F.2d 408, 413 (2d Cir. 1979) (defendant, though legally incapable of personally committing offense of fraudulently obtaining certain federal funds, held nevertheless liable where he caused innocent agent meeting capacity requirement to engage in proscribed conduct); United States v. Smith, 584 F.2d 731, 734 (5th Cir. 1978); United States v. Wiseman, 445 F.2d 792, 794-95 (2d Cir.), cert. denied, 404 U.S. 967 (1971); United States v. Lester, 363 F.2d 68 (6th Cir. 1966), cert. denied, 385 U.S. 1002 (1967). For discussions of $\S 2$ (b), see Lanham, supra note 15, at 502-06; Note, The Scope of Accomplice Liability Under 18 U.S.C. \& 2(b), 31 CASE W. ReS. L. REV. 386 (1981).

184. See statutes cited in 1 Wharton's Criminal Law, supra note 17 , at 160 n.15.

185. Model Penal CODE § 206(2)(a) (Proposed Official Draft 1962). 
tional innocent-agency doctrine do not attach. ${ }^{186}$

\section{B. Partly Culpable Actions}

The partly culpable principal presents the same problems for complicity doctrine as the wholly innocent principal: since the accoinplice's culpability is derived from that of the principal, the limit of the accomplice's culpability is determined by that of the principal. Thus if the principal is not guilty, the secondary actor cannot be held liable as his accomphice; and if the principal is culpable of a given crime, the accomplice cannot be held for a higher one.

For a case, we may once again resort to Othello. Iago dehiberately influenced Othello to kill Desdeinona by making him erroneously believe that Desdeinona had been unfaithful and by otherwise inflaming his jealousy and vengefulness. Othello would be guilty of a culpable homicide, but perhaps only of manslaughter in view of the circumstances. Iago, however, acted with greater culpability, since he coldbloodedly engineered the killing. Could he be held for the crime of murder? The answer would appear to be no under the standard comphicity doctrine, and it is clear that the text writers thought so. For example, Hawkins concluded that the accoinplice's crime could rise no higher than the principal's: "it seeming incongruous and absurd that he who is pumshed only as a partaker of the guilt of another, should be adjudged guilty of a higher crime than the other."187

Incongruous yes; absurd no. What would be absurd is to convict Iago of no more than inanslaughter because Othello was carried away by a storn of jealousy. Here is another instance of doctrinal logic defeating itself. The dilemma could be avoided under common law rules in one situation-where the secondary actor was present giving aid or encourageinent at the timie of the principal's crime. ${ }^{188}$ In these circumstances

186. The Model Penal Code's formulation introduces still another change in the traditional innocent-agency doctrine by dispensing with the requirement of intent. It has generally been required that the defendant intentionally use the actions of the innocent agent for his purpose. See infra note 209 and accompanying text. However, it is enough under the Model Penal Code that the defendant act with the mens rea required for the offense. Thus, a defendant may be held liable for causing the acts of an innocent agent even if he does so recklessly or negligently, so long as no greater mens rea is required for the crime with which he is charged. I will return to this feature of the Model Penal Code's provision in the next Section when dealing with the problein of the hability of a defendant for unintended actions of another person. See infra text accompanying notes 225-31.

187. 2 W. Hawkins, A Treatise of the Pleas of the Crown ch. 29, $\S 15$, at 442 (8th ed. London 1824) (1st ed. London 1716); see also 4 W. BLACKSTONE, supra note 24, at *36 (footnote omitted): "It is a maxim, that accessorius sequitur naturam sui principalis: and therefore an accessory cannot be guilty of a higher crime than his principal; being only purnished, as a partaker of his guilt."

188. 1 E. EAST, supra note 127, at 350; 2 W. HAwKINS, supra note 187 , ch. 29 , § 7, at 438-39. This passage of East has been cited to support the proposition that at common law the instigator could be held liable for a greater crime than the principal. See G. Williams, supra note 10, at 373 
the secondary actor would be a principal (of the second degree), rather than an accomplice, and as such his liability would be direct and not derivative. ${ }^{189}$ While the distinction has been reaffirmed in a recent English case, ${ }^{190}$ it is widely regarded as anomalous, ${ }^{191}$ since whatever the difficulties of comphicity doctrine in these situations, they are only worsened by a distinction turning on where the aid was given.

Notwithstanding these doctrinal constraints, later cases have sometimes imposed greater liability on the accomplice than on the principal. These cases are comparable to Othello, in that the accomplice is held to a higher homicidal crime than the principal is. ${ }^{192}$ The opinions, however, do little to justify the result in terins of complicity doctrine, or any other, leaving us with the question of whether it can be defended.

It is tempting to reason that the liability of the parties is determined by the culpability of each, and that the actus reus of the principal may be

\& n.2. However, East's comment concerned an "abettor" present at the scene of the crime and instigating the primary party to commit the crime. He was stating the eonventional position for second-degree principals rather than announcing a novel position for accessories.

189. Commonwealth v. Knapp, 26 Mass. (9 Pick.) 495, 513 (1830) (emphasis in original): By the most ancient common law, as it was generally understood, those persons only were considered as principals in murder, who actually killed the man, and those who were present, aiding and abetting, were considered as accessories. So that if he who gave the mortal blow were not convicted, he who was present and aiding, being only an accessory, could not be put upon his trial. But the law was otherwise settled in the reign of Henry IV. It was then adjudged, that he who was present, aiding and abetting him who actually killed, was to be considered as actually killing, as much as if he had given the deadly blow. The law has been so understood from that time to the present....

This was manifest in the rules pernitting a principal in the second degree, unlike an accessory, to be prosecuted even though the principal in the first degree had not been convicted. See Standefer $v$. United States, 447 U.S. 10, 15 (1980); Knapp, 26 Mass (9 Pick.) at 513-14; see also 1 E. EAST, supra note 127 , at 351 (one present aiding and abetting may be convicted notwithstanding acquittal of perpetrator); M. FOSTER, supra note 60 , at 427 :

[At one time] the law was taken to be, that persons present aiding and abetting were to be considered in the rank of accessaries, not liable to answer till the priitcipal was convicted or outlawed: but the mischiefs of this rule were very great and many. The persons who were then esteemed the only principals might die before conviction: their accomplices might dispatch them, in order to produce their own immunity .... .

But see 2 W. HAWKINS, supra note 187 , at $449-51$ (accessory may not be convicted if principal has been acquitted or, through death, absence, or some other circumstance, is unavailable for prosecution).

190. Regina v. Richards, [1974] 1 Q.B. 776, 780.

191. See, e.g., J. SMITH \& B. HoGAN, supra note 130, at 139-40; G. W1LL1AMS, supra note 10, at 373-74; 1974 CRIM. L. REV. 96 (case commentary).

192. See, e.g., Bridges v. State, 48 Ala. App. 249, 251-52, 263 So. 2d 705, 707-08 (1972); State v. Gray, 55 Kan. 135, 144-45, 39 P. 1050, 1053 (1895); State v. McAllister, 366 So. 2d 1340, 1342-43 (La. 1978); State v. Dault, 25 Wash. App. 568, 572-74, 608 P.2d 270, 273-74 (1980); see also Moore v. Lowe, 116 W. Va. 165, 168-71, 180 S.E. 1, 2-4, cert. denied, 296 U.S. 574 (1935), overruled on other grounds by State v. Petry, 273 S.E.2d 346 (W. Va. 1980); G. WilLiaMS, supra note 22, at 390. 91. Cases to the contrary seem to go off on the now generally discarded view that the prior conviction of the principal determines the crime of which the aceomplice may be convicted, regardless of what can be proven in the subsequent trial of the accomplice. See, e.g., Schmidt v. State, 261 Ind. 81 , 81-83, 300 N.E.2d 86, 87-88 (1973); State v. Ward, 284 Md. 189, 201-07, 396 A.2d 1041, 1049-52 (1978), overruled on other grounds by Lewis v. State, $285 \mathrm{Md} .705,404$ A.2d 1073 (1979). 
attributed to the secondary party so that it may be considered with the secondary party's mens rea to determine his liability. The flaw in this, as we have seen, is that complicity doctrine affords no justification for attributing the actions of the principal to the secondary party. A natural move, then, is to the one major instance in which the actions of the principal, and not simply his guilt, may be attributed to the secondary actor. This is the doctrine of innocent agency.

The question that arises, however, is whether that doctrine is applicable in the Othello hypothetical. After all, Othello is a culpable, not an innocent actor. The argument that the doctrine is applicable is that Othello is, after all, Iago's tool, and not less so because he was maneuvered into committing a crime. On the facts in the play this is readily apparent-through deceit and misrepresentation Iago led Othello to believe the situation to be radically different than it was. Had the misrepresentation been that Desdemona had committed the capital offense of treason, leading Othello to order her execution, Othello would presumably be innocent. But in that case, Iago plainly could be held for murder on the innocent-agency doctrine: smce Othello was acting on a false view, his action was not fully volitional, and Iago, in dehberately inducing it, could be held to have caused the killing. It should make no difference that Iago's fabrication served only to mitigate Othello's guilt rather than to exculpate him. As Professor Williams observed, "If a person can act through a completely innocent agent, there is no reason why he should not act through a semi-innocent agent. It is wholly unreasonable that the partial guilt of the agent should operate as a defence to the instigator." 193

The common sense of this conclusion is clear enough, but the conceptual difficulty remains that Othello acted culpably and responsibly in intentionally killing his wife. There is, to be sure, some rhetorical force in speaking of him as Iago's tool, maneuvered mto doing what Iago wanted him to do. But since Othello committed an action for which he himself is responsible, it is straining to say im the same breath that, on the theory of innocent agency, his act was (also) the act of Iago. Professor Williams coins the phrase "semi-innocent agent" to describe the situation, and suggests that the primary party be regarded as "an innocent agent in respect of part of the responsibility of the secondary party."194 However, the ideas of a "semi-innocent agent" and of responsibility as a coinposite of parts seein only to add to the conceptual mystery.

Perhaps a better doctrimal explanation of what is obviously the sound result in these cases is simply to regard the secondary party as causing the death of the victinn. As Hart and Honore have shown, it is

193. G. WILliams, supra note 10 , at 374 .

194. G. WiLliams, supra note 22, at 391. 
quite consistent with the law of causation to trace the causal inquiry through an intervening actor to the end result in those cases where the action of the intervening actor is not wholly voluntary. ${ }^{195}$ Cases applying this concept to hold a secondary party liable for a result caused by a primary party usually occur in situations where the secondary party did not intend the principal's action. ${ }^{196}$ The analysis would appear to be no less appropriate where the secondary actor intended the principal's action, so long as the latter's action was not fully voluntary. In the Othello example this is plainly the case. That Othello's actions are not excused is not an obstacle to this analysis. The intervening action need only be less than wholly voluntary to perinit tracing the causal inquiry through the intervening actor; it need not be so nonvoluntary as to be fully excused. ${ }^{197}$ Once it is established, of course, that Iago caused the death of Desdeniona it follows that the nature of his crime is determined by the culpability with which he acted. ${ }^{198}$

It follows that the greater liability of the secondary party can be supported only where some feature of the priniary party's action is not volitional in the full sense, so that the former can be said to have caused it by using the latter as his instrunient. This limitation is illustrated in Regina v. Richards. ${ }^{199}$ Mrs. Richards hired two nien to beat her husband severely, but the nien instead (so the jury apparently found) chose to inflict only a ninor assault. The jury convicted the men simply of unlawful wounding, but convicted Mrs. Richards of the offense of wounding with intent to cause grievous bodily harm. The appellate court reduced her conviction to unlawful wounding, on the view that as an inciter, her guilt could not be greater than the principal. The case has been criticized, ${ }^{200}$ and insofar as the decision rested on the distinction between whether the secondary party was present or not, the criticisn1 is well taken. ${ }^{201}$ But the decision is supportable, it would seem, on the ground that Mrs. Richards did not cause the actions of the nien.

Critics of the Richards decision have taken a different view. Smith and Hogan, for example, argue by analogy to a person, $D$, who gives poison to another, $E$, to administer to the deceased, telling $E$ it is an enietic that will cause only discomfort. They argue that if $D$ had told $E$

195. H.L.A. HART \& A. HoNORÉ, supra note 5, at 323-24.

196. See infra pp. 391-98.

197. H.L.A. HART \& A. HONORE, supra note 5, at 296-304.

198. This explanation would not work if the case had been that Iago was speaking the truth. But, as we saw earlier, there is a real question whether in that event as a matter of penal policy any liability at all, based either on complicity or causation, is appropriate. See supra text accompanying notes 109-10.

199. [1974] 1 Q.B. 776.

200. See J. Smith \& B. Hogan, supra note 130, at 140; G. Williams, supra notc 10, at 373-74.

201. See supra text accompanying note 191. 
that the poison was medicine the deceased needed, $D$ would unquestionably be guilty of murder. It should make no difference that $D$ told $E$ the poison was an emetic, which, simce $E$ 's action would then have been an intentional assault, would have made $E$ guilty of manslaughter. They conclude: "The true principle . . . is that where the principal has caused an actus reus, the hability of each of the secondary parties should be assessed according to his own mens rea.,"202

Their conclusion that $D$ is liable for murder is sound, but the generalization they adduce to support it is questionable. It is not a "true principle" that the secondary party's liability is assessed according to his own mens rea when the primary party "has caused an actus reus." This is true only when the secondary party can be said to lave caused the actions of the primary party, thereby bringing into play the doctrine of causation which, unlike the doctrine of complicity, does not rest on a derivative theory of liability. In Smith and Hogan's hypothetical this is the case, since $D$ used $E$ as lis unwitting instrument. But it is not the case with Mrs. Richards. She made no misrepresentation to the men slie hired. They were not her unwitting instruments, but freely chose to act as they did. Hence their actions, as sucli, could not be attributed to Mrs. Richards. The innocent-agency doctrine is mapplicable because she did not cause their action. ${ }^{203}$

It is a furtlier question whetlier Mrs. Ricliards should be liable for assault with intent to do grievous injury, even if I am right that existimg doctrine precludes that result. Surely the strongest argument for hability is that the culpability of her hirelimgs is irrelevant to her culpability. But that argument proves too much. If lier hirehings committed no assault, but instead went to the police, it is incontrovertible that Mrs. Richards could not be found liable for any assault, let alone an aggravated assault. Yet whetlier lier hirelings chose to do as she bade them or to go to the police is also irrelevant to lier culpabihity. The point would be that however culpable her imtentions she could not be blamed for an assault that did not take place. The same retort is applicable on the facts of the case: an actual assault took place (and Mrs. Richards is hable for it) but an aggravated assault did not take place. It did not take place because those committing the assault did not intend to inflict grievous bodily harm. She could properly be held liable for solicitation to commit an aggravated assault, not for aggravated assault.

Even critics of the decision would probably find this reasoning

202. J. SmITH \& B. Hogan, supra note 130, at 140; see also Note, Proof of Principal Offences and Liability of Secondary Party, 90 LAw Q. Rev. 314, 318 (1974).

203. The same argument applies to Professor Williams' criticism of the Richards case. See G. WILIIAMS, supra note 10 , at 373-74. 
appropriate in a case where the pseudo-principal was only feigning. ${ }^{204} \mathrm{~A}$ secondary party may be culpable of seeking to help a principal cominit a burglary, by boosting him through a transom, for example, but as we have seen, if the principal has no intention of committing a felony, but is acting solely to ensnare the secondary party, the latter cannot be held as an accomplice to the burglary. ${ }^{205}$ This follows because the pseudo-principal has committed no burglary, and his actions, being wholly volitional acts done with his eyes wide open, cannot be attributed to his misguided helper. The identical reasoning precludes holding Mrs. Richards liable for an aggravated assault: her hirelings committed no aggravated assault. The only difference is that there is no evidence that her hirelings were inotivated by a desire to ensnare her. But could it be argued convincingly that if there were such evidence the case should come out differently? It is hard to see why the ultinate inotive of the primary actor should require a different result. It is rather his mens rea as to the action that is decisive.

So much, then, for the uses and linits of causation in justifying holding an accomplice hable for a greater crime than the principal. The last question I want to raise is whether there is an alternative doctrinal inove for accomphishing the saine purpose. The one that innnediately suggests itself is the doctrine discussed in the preceding section on the nonculpable principal. ${ }^{206}$ If it is plausible to base an accoinplice's liability upon the "wrong" committed by an "excused" prinnary actor who is thus guilty of no crime, it is equally plausible to base an accoinplice's liability on the wrong of a partly culpable primary actor. Thus, in our Othello hypothetical, Iago's liability for murder would be justified on the view that what is imputed to the accomplice is the legal wrong Othello committed. Othello committed the crime of inanslaugliter, not murder. But the basis of the accomplice's liability is not the crime of which the principal is guilty, but the legal wrong the principal cominitted, here the unlawful killing of Desdemona. The derivative nature of Iago's liability having been thus respected, it is possible to assess his actual legal guilt for sharing in that wrong in terins of his own inens rea.

How would Mrs. Richards fare under this analysis? Would it require that she be held hable as an accoinplice to aggravated assault? On the one hand, it is clear that the hirelings committed the legal wrong of an ordinary assault on her husband. Perhaps this would be enough to permit her guilt to be determined by her intention that her husband slould be severely beaten. On the other hand, it does not appear accurate to say that that the hirelings did the wrong of an aggravated assault

204. See, e.g., id. at 372-73.

205. See supra note 21 and accompanying text.

206. See supra text accompanying notes 170-77. 
but are innocent because of an excuse personal to them. It seems more apt to say that they are innocent of the aggravated assault because they did not commit the crime as defined, specifically because they did not assault with intention to inflict grievous injury. On this view the "innocent wrong" theory would not sustain Mrs. Richards' liability for the aggravated assault.

\section{Unintended Actions}

The doctrines governing the hability of one person for the crimes or acts of another that we liave canvassed to this point require that the secondary actor have intended that the primary actor act as he did. This is plainly the case for complicity liability as a general proposition. It is no less true im cases of comphicity to manslaughter, where the intent requirement is satisfied by the intent that the principal should do the reckless act that caused the death. We saw one imstance where the intention requirement was in doubt, namely, those occasional cases and statutes that make it sufficient that the principal's criminal act was a probable consequence of the action the secondary party imtended. But even those instances were subject to the limitation that the actions of the primary party further the ends of the secondary actor. The requirement of an intentional action also apphies to the innocent-agency doctrine, since it rests on the notion of agency as a basis for attributing the acts of the innocent party to the instigator.

The doctrines we have so far examined, therefore, leave uncovered situations in which the fault of the secondary actor lies in engaging in conduct tliat creates the danger (whicl in fact materializes) that some other person will engage in criminal conduct, whether or not that conduct serves the purposes of the secondary actor. In order to deal with these cases, courts have sometimes invoked the concept of causation, not in the sense of the innocent-agency doctrine, which makes the actions of the innocent party the actions of the intentional instigator, but in the sense that allows the instigator to be treated as liaving caused the result of the actions of soine other person. The problem raised by this use of causation follows from the characteristic ways in which huinan actions are conceived as taking place. Actions are seen not as caused happenings, but as tlie product of the actor's self-deternined choices, so that it is the actor who is tle cause of what he does, not one who set the stage for liis action. For purposes of considering this and related problems of the use of causation in these cases it will be helpful to consider separately cases where the action of the second actor is not wholly volitional and those where it is. 


\section{Nonvolitional Actions}

Consider, first, cases like the following: A person leaves his car keys with a legally irresponsible person known to have a penchant for wild driving, who kills another person while driving the car. ${ }^{207} \mathrm{~A}$ person shoots at police, inviting return fire that kills a bystander or another felon. A person creates a justifiable apprehension of danger in his victim, who kills another accidentally while defending himself. ${ }^{208}$

A special feature of these cases is that the primary actor's conduct is not wholly volitional. This was the feature of the situations treated in the preceding Sections on nonculpable and partly culpable actions that permitted application of the causation concept to hold the secondary actor hable. Because in addition to the nonvolitional character of the primary actor's actions, the secondary actor intentionally used the primary actor to achieve his purposes, it was possible to apply the doctrine of innocent agency to hold the secondary actor to have caused the actions of the primary actor. In consequence, the innocent agent's actions could be attributed to the secondary actor (so that he becomes liable if those actions are prohibited), and he could properly be said to have caused the result of those actions (so that he becomes liable also if the crime consists of causing that result).

However, in the cases now under consideration the secondary actor does not intentionally help or instigate the acts of the prinary actor. On the generally accepted view, therefore, the innocent-agency doctrine is inapplicable ${ }^{209}$ and the primary actor's actions cannot be attributed to the secondary actor. But the nonvolitional character of the primary actor's actions makes it possible to treat the secondary actor as having caused the result of those actions. This is so because nonvolitional actions, unlike volitional ones, do not serve as a barrier to tracing a causal inquiry through those actions to those of an antecedent actor. ${ }^{210}$ To this extent the nonvolitional action of the primary actor is treated as a natural event for purposes of finding the cause of some result. For convenience we may refer to this as the "result causing" analysis.

Decisions that have held a person liable for recklessly risking criminal harms inflicted by others appear to rest on just such an analysis. This is inost helpfully seen in a class of felony-murder cases where the action of a person resisting the felony results in a homicide-sometimes of a cofelon, sometimes of a bystander or another victim. The artificialities of the felony-inurder doctrime tend to obscure the force of an analysis in these terms, since that doctrine holds a felon for murder when his precip-

207. Model Penal Code \$204(2)(a) comment at 17 (Tent. Draft No. 1, 1953).

208. Id.

209. See H.L.A. HART \& A. HoNORE, supra note 5, at 323-25.

210. See supra text accompanying notes $4-7$. 
itating acts may have been done with recklessness or some lesser mens rea insufficient for inurder. Thus, in a number of cases where a bystander or a cofelon was killed by the victim or a policeman resisting the felony, courts have held a surviving felon for felony murder, without attending to anything more than that the victim died as a proximate result of the felony committed by the defendant ${ }^{211}$ - the so-called "proximate cause theory."212 Reacting against those cases, recent decisions have rejected the applicability of felony murder in these situations, holding that the doctrine may not be used to convict a felon of felony murder unless the killing was committed by the felon or one who is his accomplice acting in furtherance of their cominon design ${ }^{213}$ - the so-called "agency theory" of felony murder. ${ }^{214}$

At all events, we are not now concerned with the hability of the actors in these cases for murder under the very special rules of the felony-murder doctrine, but their liability under standard doctrine for some appropriate category of homicide. (This would normally be manslaughter since the fault of the actor, so far as the homicide is concerned, is recklessness.) Therefore, we need to examine these situations apart from the distortions of the felony-murder doctrine.

The agency theory (which is to say, the standard doctrine of complicity) plainly cannot, apart from the special force of the felony-murder doctrime, justify imposing liability on a felon for killings committed by those who are not his accomplices. Likewise, the proximate-cause theory cannot, apart from felony murder, justify holding the felon for murder when such killings occur, unless recklessness or some lesser mens rea is deemed sufficient for murder, and certainly cannot justify holding him for first-degree murder, which requires an intentional killing. ${ }^{215}$ But the causation theory, wholly apart from the felony-murder doctrine (though,

211. See, e.g., Commonwealth v. Almeida, 362 Pa. 596, 68 A.2d 595 (1949), cert denied, 339 U.S. 924 (1950), overruled by Commonwealth ex rel. Smith v. Myers, 438 Pa. 218, 261 A.2d 550 (1970); Commonwealth v. Moyer, 357 Pa. 181, 53 A.2d 736 (1947).

212. See State v. Canola, 73 N.J. 206, 213, 374 A.2d 20, 23 (1977).

213. People v. Washington, 62 Cal. 2d 777, 783, 402 P.2d 130, 134, 44 Cal. Rptr. 442, 446 (1965); see also State v. Canola, 73 N.J. 206, 374 A.2d 20 (1977); Commonwealth v. Allen, 475 Pa. 165,379 A.2d 1335 (1977).

214. See State v. Canola, 73 N.J. 206, 225, 374 A.2d 20, 30 (1977). Recent statutory formulations of the felony-murder doctrine have taken various positions. These statutes commonly exclude the death of one of the felons as a basis for felony murder, regardless of who does the killing. See, e.g., CONN. GEN. STat. ANN. § 53a-54c (West Supp. 1984); N.Y. PENAL LaW § 125.25 (McKinney Supp. 1984). For some doubts on the defensibility of this position, see S. KADISH, S. SCHULHOFER \& M. PAULSEN, supra note 126, at 498-500. Many statutes appear to confine felony murder to killings committed personally by the felon or his accomplice (the agency theory), although the statutory language sometimes leaves room for doubt. See, e.g., CoLo. REV. STAT. $\$ 18-3-102$ (1978); N.J. STAT. ANN. \& 2C:11-3 (West 1982).

215. However, this is the conclusion reached in California under a peculiar interpretation of its homicide statutes. Pizano v. Superior Court, 21 Cal. 3d 128, 577 P.2d 659, 145 Cal. Rptr. 524 (1978); Taylor v. Superior Court, 3 Cal. 3d 578, 477 P.2d 131, 91 Cal. Rptr. 275 (1970). 
of course, subject to the usual limitations of remoteness ${ }^{216}$ ), can justify holding the felon liable for causing the homicide committed by a nonfelon in resisting the felony. What level of homicide depends, of course, on the extent of the felon's recklessness in the circumstances.

The California cases offer useful illustrations, since they have most clearly articulated the rationale for holding a felon liable for causing a killing done by a nonfelon in resisting the felony, quite apart from the felony-murder doctrine. ${ }^{217}$ The theory for holding the felon in these cases was expounded shortly after the applicability of felony murder had been rejected. In People v. Gilbert, ${ }^{218}$ the court reasoned:

When the defendant or his accomplice, with a conscious disregard for hife, intentionally commits an act that is likely to cause death, and his victim or a police officer kills in reasonable response to such act, the defendant is guilty of murder. In such a case, the killing is attributable, not merely to the commission of a felony, but to the intentional act of the defendant or his accomplice committed with conscious disregard for life. Thus, the victim's self-defensive killing or the police officer's killing in the performance of his duty cannot be considered an independent intervening cause for which the defendant is not liable, for it is a reasonable response to the dilemma thrust upon the victim or the policeman by the intentional act of the defendant or his accomplice. ${ }^{219}$

Subsequent decisions have not had occasion to decide whether the felon may be hable for manslaughter when his acts lack the mens rea required for murder, although the court's analysis would seem to support the possibility. Instead, the decisions have focused on the kinds of provocative actions that manifest the "conscious disregard for life" necessary for murder. ${ }^{220}$ This attention to mens rea is irrelevant to our concern here, which is causation. The decision in Gilbert, however, is gernnane because it indicates that in some circumstances-where the killing is committed by a policeman perforning his duty or a victim exercising his privilege of self-defense-the action of the intervening actor does not constitute an intervening cause, and therefore pernits the cause of the death to be traced to the initiating action of the felon. The court has not explicitly spoken of the actions of the policeman or the victim as

216. Cf. Taylor v. State, 41 Tex. Crim. 564, 572, 55 S.W. 961, 964 (1900).

217. See, e.g., People v. Washington, 62 Cal. 2d 777, 781, 402 P.2d 130, 133, 44 Cal. Rptr. 442, 445 (1965) ("When a killing is not committed by a robber or by his accomplice but by his victim, malice aforethought is not attributable to the robber, for the killing is not committed by him ....").

218. 63 Cal. 2d 690, 408 P.2d 365, 47 Cal. Rptr. 909 (1965), vacated on other grounds, 388 U.S. 263 (1967).

219. Id. at 704, 408 P.2d at 373, 47 Cal. Rptr. at 917 (emphasis added). The formula the court uses is the formula in California for elevating an egregiously reckless killing to murder.

220. See Taylor v. Superior Court, 3 Cal. 3d 578, 477 P.2d 131, 91 Cal. Rptr. 275 (1970); People v. Washington, 62 Cal. 2d 777, 402 P.2d 130, 44 Cal. Rptr. 442 (1965). 
being less than wholly volitional, but it characterized those actions as "a reasonable response to the dilemma" thrust upon them, which seems to imply restricted volition. The constrained character of the policeman's or victim's actions distinguishes the usual case where the imdependent action of an intervening actor blocks tracing the cause of the result to another person's earlier action. ${ }^{221}$

A recent Enghish decision ${ }^{222}$ puts the matter quite explicitly. The defendant was convicted of manslaughter of a girl who was in fact shot by a policeman. The defendant, who had already shot and imjured others, held the girl as a shield agamst the policemen and opened fire upon them. The policemen returned his fire and accidentally killed the girl. In affirming the conviction, the court of appeal rejected the reasoning of a number of American cases that hold the defendant not hable for murder in these situations, on the ground that those cases were interpretations of the felony-murder concept, which had long since been abandoned in England. The court rejected as well the argument that the shooting by the policemen was a novus actus interveniens that severed the defendant's causal relationship to the girl's killing. It held that, under ordinary principles of causation, the acts of the policeman were not novus actus interveniens, since they were done either out of self-defense or in the execution of duty, and hence were not voluntary actions in the sense required to make them, rather than the defendant's prior actions, the cause of the girl's death. ${ }^{223}$

The Model Penal Code's approach to these matters is worth noting because it constitutes something of a departure from traditional causation doctrine. It plainly accepts the liability of the defendants in the kinds of hypotheticals and cases under consideration, ${ }^{224}$ but formnlates the principle in terms somewhat wider than the traditional result-causing analysis. The relevant provision is the same one discussed earlier, Section 2.06(2)(a), which substitutes an action-causing doctrine for the innocent-agency doctrine. We may repeat it here: "A person is legally accountable for the conduct of another person when . . . acting with the kind of culpability that is sufficient for the commission of the offense, he causes an innocent or irresponsible person to engage in such conduct.",225

221. It should be said that third-party felony-murder cases in other jurisdictions are also consistent with this interpretation. The cases that adopt the so-called proximate cause theory of the felon's liability most clearly rest on just such a causation analysis. The felony-murder artificialities enter the picture only after causation has been established. The cases and statutes adopting the agency approach reject the causation approach only for the purposes of the stringencies of the felony-murder rule. They do not consider the liability of the felon for manslaughter (or even murder) apart from the felony-murder doctrine.

222. In re Pagett, 76 Crim. App. 279 (1983).

223. Id. at $288-90$.

224. See Model Penal Code $\S 2.04(2)$ (a) comment at 17-18 (Tent. Draft No. 1, 1953).

225. Id. $\$ 2.06(2)(a)$ (Proposed Official Draft 1962). 
In dispensing with the requirement of intention, the Model Penal Code departs from traditional causation analysis. There is no doctrinal obstacle to holding a person for unintentionally causing a prohibited result, even though an action of an innocent or irresponsible person intervened. This is because our conception of causation permits tracing the cause of some result through a nonvolitional actor to an antecedent actor. The latter's action may be found to be the cause of the result even if he did not intend the action of the nonvolitional actor. As Hart and Honorés review of the causation cases reveals, however, it is different with causing actions, even nonvohitional ones. Actions, like results, can be caused, but only by acts intended to cause them.

[A]n element of intention (imtending the other to act in a specified way) is essential if one person is to be said to 'cause' another to act but not when he is said to cause some event to happen. This is . . not an independent legal requirement of a certain state of mind in the accused person, but part of the meaming of 'causing' in the sense of providing a reason for the non-voluntary act of another. ${ }^{226}$

The Model Penal Code eliminates this distinction and treats nonvolitional actions as capable of being caused accidentally as well as intentionally. ${ }^{227}$

Professor Williams early criticized this feature of the Model Penal Code. Positing the case of a victim of an armed assault who accidentally shoots a bystander while justifiably resisting the assault, he questions the theory under which the Model Penal Code would find the author of the assault guilty of manslaughter, ${ }^{228}$ namely by treating him as negligently causing the lethal act of the innocent person. Williams prefers to treat the author of the assault as having directly caused the death, subject to the normal himitation that the death is not too remote a consequence of

226. H.L.A. HART \& A. HONORE, supra note 5, at 327-28. See the proposal of the English Law Commission purporting to restate existing law: "A person acts through an innocent agent when he intentionally causes the external elements of the offence to be committed by . . . a person who is himself imnocent of the offence charged by reason of a lack of a required fault element, or lack of capacity." THE LAW COMM'N, supra note 21, at 11 (Proposition 3); cf. United States v. Chiarclla, 184 F.2d 903, 909-10 (2d Cir. 1950), cert. denied, 341 U.S. 956 (1951) (L. Hand, J.).

227. It is possible to read the Model Penal Code provision as not embracing liability for unintentionally causing nonvoluntary conduct. Literally, it only stipulates accountability when two conditions are met: when the defendant causes the innocent person to engage in the conduct, and when he acts with the mens rea required for the offense. The reading I have given the language, however, is apparently the one intended. See Model Penal Code $\$ 2.04(2)(a)$ comment at 17-18 (Tent. Draft No. 1, 1953):

When the crimes call for no more than recklessness or negligence for their commission, it should suffice . . . that one with such recklessness or negligence causes the required overt conduct by an innocent or irresponsible person; there is no reason for demanding that such conduct be caused purposively . . . .

... In short, the draft proposes to determine liability by the culpability and state of mind of the defendant, coupled with the overt behavior he has caused another to perform.

228. Id. at 17 . 
his action. 229

The Model Penal Code approach would not produce a different outcome in most cases. Where the crime is a result crime, as it normally is, both approaches would hold the first actor hable, since they would both conclude that he caused the result. Under the Model Penal Code approach he would cause it by causing the actions of the innocent person; under the traditional result-causing approach he would cause the result directly by his own act. Perhaps, as Williams suggests, the direct-causation analysis would allow more room for argument about remoteness than the Model Penal Code analysis would. Still, remoteness considerations would appear relevant as well to finding the defendant to have caused the action of the innocent person.

Many action crimes would also come out the same way, although the underlying analysis would be different. Under the Model Penal Code the issue of liability would be resolved in terms of mens rea, while under the result-causing approach it would be resolved in terms of causation. Consider a hypothetical involving an action rather than a result crime. Suppose a guard at a mental hospital recklessly leaves the keys to the drug room unattended. An irresponsible inmate finds the keys and uses thein to gain access to an annexed building that contains restricted drugs. Would the guard be guilty of the crimes of burglary and illegal possession of restricted drugs? Not under the traditional causation approach, even if causing prohibited actions is a crime, since the crimes require defined actions which he did not commit and which he could not be said to have caused, not having acted intentionally. Nor would he be liable under the Model Penal Code provision-not because he did not cause the actions, but because he did not act with the culpability required for those crimes: he did not imtend to steal (or for the inmate to steal), and he lacked the knowledge necessary for possession.

The one case in which the outcome could be different is where the prohibited action can be committed recklessly or negligently, or without mens rea at all. We have already seen that under both the result-causmg analysis and the Model Penal Code approach, a person may be held accountable if an irresponsible person with whom the defendant intentionally left his car keys causes the death of another person through reckless driving. But under the Model Penal Code the defendant could also be held liable for reckless driving since he acted recklessly, which is the culpability sufficient for the offense. Consider also the hypothetical of the guard at a mental hospital in the preceding paragraph, with the change that the crime of possession of restricted drugs is one of strict liability. Thus, the person who had the drugs withm his control would

229. G. WILLIAMS, supra note 22, at 352. 
be guilty of illegal possession whether or not he was aware that they were drugs or that he had them. Under the traditional causation analysis the guard would not be guilty of possession of the drugs since, not having intended that the mmate have possession of them, he could not be said to have caused the inmate's action of possessing them. However, it would seem that under the Model Penal Code provision the guard might be guilty, even if he were faultless in leaving the keys-if, for example, the keys fell out of his pocket accidentally while he was struggling with an unruly patient. ${ }^{230}$

Whether the Model Penal Code innovation is a desirable substitute for traditional causation doctrine in dealing with unintended actions of another is unclear. One problein is that it compels courts to resolve questions of causation without regard to a factor, the intention of the actor, that has become part of the meaning of cause in these cases. Another problem concerns the desirability of expanding criminal liability. Absent a requirement of intent that would confine liability, a substantial range of actions is put at risk, perhaps a broader range than is wise. The strict hability example I just put is a case in point. Perhaps courts could confine the scope of liability through restrictive interpretations of when one action causes another. With intention no longer a consideration, however, this may be difficult to accomplish. ${ }^{231}$

\section{Volitional Actions}

The second set of cases involving the liability of an actor for creating the danger of a primary actor's harmful actions is nore difficult to deal with in terms of causation, because the action of the one who directly causes the harm may be wholly volitional. The cases I propose to use as examples are these: The defendant lends his car keys to a person he knows to have been drinking ${ }^{232}$ or to one he knows has never driven, who

230. The Model Penal Code eliminates strict liability (except for nonimprisonable infractions, MODEL PENAl CODE $\S 2.05$ (Proposed Official Draft 1962)), but the analysis in the text would apply in any jurisdiction retaining strict liability if it adopted the Model Penal Code complicity provisions.

231. It is wortl noting that in other situations raising the issue of liability of one person for what another does, the Model Penal Code has adhered strictly to the requirement of intention, manifesting a sensitivity to widening the net of liability. To be guilty as an accomplice, for example, a person must purposively solicit or knowingly aid another to commit a crime. MODEL PENAL CODE § 2.04(3) (Tent. Draft No. 1, 1953). The comment to this section states: "Whatever may be law upon the point, it is submitted that the liability of an accomplice ought not to extend beyond the criminal purposes that he shares or knows." Id. § 2.04(3) comment at 26. It is not immediately apparent why the Model Penal Code chose to cast the net wider when a person causes an innocent person to commit a criminal action than when he influences or helps a guilty person to do so. It is also worth noting that to be guilty of criminal homicide by causing anotler to commit suicide under the Model Penal Code, a person must purposely cause the suieide by force, duress or deception. Id. § 210.5(1) (Proposed Official Draft 1962).

232. People v. Marshall, 362 Mich. 170, 106 N.W.2d 842 (1961) (defendant, who lent automo- 
kills another in an automobile accident. The defendant engages in a road race on a public street in the course of which his competitor collides with another car, resulting in the competitor's death ${ }^{233}$ or the death of the driver of the other car. ${ }^{234}$ We may include also the case of a defendant who engages in a game of Russian roulette with another, in the course of which the other shoots and kills himself. ${ }^{235}$ Here, while the defendant may be said to have intentionally encouraged the deceased to fire the revolver at himself, to the extent the deceased committed no crime there is no liability in which the defendant may be said to participate. Barring a special statute, causation offers the only plausible ground for holding him responsible.

It may be thought at first blush that comphicity liability is possible in these cases (putting the Russian roulette example aside), for as we have seen, there is no conceptual barrier to holding a person as an accomplice to a crine of recklessness, like imvoluntary manslaugliter. Where a secondary actor influences or helps another to commit acts that are sufficiently reckless that if death results, the other is guilty of manslaugliter, the secondary actor shares his liability as an accomplice. While he does not intend the resulting death, he does intend that the principal do the acts that turn out to cause it. ${ }^{236}$ This analysis does not apply, however, to the cases we are now considering. As we saw earher, this is because the deaths were not caused by those actions of the other party that the secondary actor intended (in the way, for example, the heating of a defective boiler causes it to explode ${ }^{237}$ ), but by actions of the other party that, while perhaps probable and foreseeable, were not intended by the secondary actor. The defendant who lends his car keys to a person he knows has been drinking intentionally aids him to drive, but not to drive in a way that causes death. A party to an automobile race on a public street may be said to intend (or at least to know) that his competitor will speed, but not that lie will, for example, try to pass another car on a two-lane road at the crest of a hill. Therefore, the defendant cannot norinally be held as an accomplice under standard complicity doctrine.

The failure of traditional doctrine to provide for liability in these situations, where the culpable consequence of defendant's action is some

bile keys to drunk who was then involved in fatal crash, found not guilty of involuntary manslaughter, but could be held for negligence).

233. Commonwealth v. Root, $403 \mathrm{~Pa}$. 571, 170 A.2d 310 (1961) (conduct of defendant in accepting challenge to engage in automobile race could not justify conviction for involnntary manslaughter for death of the challenger).

234. Jacobs v. State, 184 So. 2d 711 (Fla. Dist. Ct. App. 1966) (defendant who recklessly drove in automobile race where driver of oncoming vehicle was killed held guilty of manslaugher).

235. Commonwealth v. Atencio, 345 Mass. 627, 189 N.E.2d 223 (1963) (defendants, who participated in Russian roulette, hable for involuntary mansalughter).

236. See supra text accoinpanying notes 44-48.

237. See State v. McVay, 47 R.I. 292, 132 A. 436 (1926). 
unintended but voluntary action of another, has produced a tension in the law. We saw this earlier in the cases and statutes that seem to reject the requireinent of intentionality for complicity liability in favor of a standard of recklessness. ${ }^{238}$ So in causation we may observe an analogous pressure to depart froin the view that voluntary actions are not caused in order to provide a ground for iniposing liability. ${ }^{239}$

This tension is apparent in the decisions. In Commonwealth $v$. Root, ${ }^{240}$ for example, the defendant and deceased engaged in an automobile race on a rural highway, reaching speeds of ninety miles per hour. At one point, in seeking to pass defendant, deceased pulled out in a nopassing zone where the road narrowed as it approached a bridge and collided with a truck coming froin the opposite direction. He was killed in the crash and the defendant was convicted of involuntary nianslaughter. The inajority of the Pennsylvania Suprenie Court reversed the conviction in recognition of the inappropriateness of tracing through the voluntary actions of the deceased to find the cause of the death in the defendant's prior actions. ${ }^{241}$ The court regarded the defendant's recklessness as having been established. More was required, however: for hability to attach he must be shown to have been the direct cause of the death. ${ }^{242}$

[T] he action of the deceased driver in recklessly and suicidally swerving his car to the left lane of a 2-lane highway into the path of an oncoming truck was not forced upon him by any act of the defendant; it was done by the deceased and by him alone, who thus directly brought about his

238. See supra notes $64-70$ and accompanying text.

239. See supra text accompanying note 185.

240. 403 Pa. 571, 170 A.2d 310 (1961).

241. In commenting on the decision of the intermediate appellate court, which had affirmed the conviction, Professor Williams advances a different reason for reversal than that later invoked by the Supreme Court: since the deceased committed no crime in causing his own death by his reckless action, there was no homicidal crime for which the competitor could be held as a secondary party. G. WILlIAMS, supra note 22, at 393-94. This, however, is to treat the defendant's liability in terms of complicity, rather than causation. Complicity in any event does not fit here, since the deceased died as a result of a dangerous action his competitor did not intend. Professor Williams adds in a footnote that neither can the doctrine of causation make a person a party to a nonexistent crime. Id. at $394 \mathrm{n} .13$. But the issue is the survivor's liability for recklessly causing the death of the competitor, which is a crime.

There may be good reasons for not extending liability to one who helps another to expose himself deliberately to a great risk. Professor Williams instances two mountain climbers who undertake a foolhardy climbing attempt under particularly dangerous circumstances in the course of which one of them falls to his deatl. Id. at 393 . There is force in the policy argument that a person sliould not suffer criminal liability for lelping another to subject himself to risks le is free to assume. But that policy is consistent with the standard causation doctrine, as the decision of the Pennsylvania Supreme Court reveals, since it precludes regarding the helper as causing the other party's wholly volitional action. In any event, the issue does not affect our main concern, for as far as the logic of the court's decision was concerned the decision might just as well have involved the death of a nonparticipant. Root, $403 \mathrm{~Pa}$. at 589, $170 \mathrm{A.2d}$ at 318 (Eagen, J., dissenting).

242. Root, $403 \mathrm{~Pa}$. at 574,170 A.2d at 311 . 
own demise. ${ }^{243}$

The deceased's voluntary actions were an "intervening cause," sufficient to bar the defendant's liability for causing the death. The court took note of several tort cases that had expanded proximate cause to include the foreseeable actions of others, but regarded it as inappropriate to apply them to criminal cases. ${ }^{244}$ The policies of tort law may justify expanding the concept of cause in order to permit an injured party to recover compensation from a tortfeasor, but it did not seem to the court to follow that a similar expansion is justified when the stakes are criminal liability for homicide. ${ }^{245}$

The dissent, on the other hand, was more persuaded by tlie soundness in penal policy of liolding the defendant liable tlian by the strictures of causation analysis:

If the defendant did not engage in the unlawful race and so operate his automobile in such a reckless manner, this accident would never have occurred. He helped create the dangerous event. He was a vital part of it. The victim's acts were a natural reaction to the stimulus of the situation. The race, the attempt to pass the other car and forge ahead, the reckless speed, all of these factors the defendant himself helped create. He was part and parcel of them. That the victim's response was normal under the cirumstances, that his reaction should have been expected and was clearly foreseeable, is to me beyond argument. That the defendant's recklessness was a substantial factor is obvious. All of this . . makes his unlawful conduct a direct cause of the resulting collision. ${ }^{246}$

Cases involving the liability of a person who lends his car to a person he knows to have been drinking, where the latter kills another by his reckless driving, are usually concerned solely with whetler the lender may be held as an accomplice to inanslaugliter. We have seen the difficulties witl concluding that he may be. ${ }^{247}$ There is little evidence of courts resorting to causation as an alternative stratagem, ${ }^{248}$ but Professors LaFave and Scott have proposed that solution. They argue that the mens rea of manslaughter is satisfied if tlie lender's action in lending his car to an intoxicated driver was criminally negligent, and the actus reus is satisfied if that action is found to be the legal cause of

243. Id. at $576,170 \mathrm{~A} .2 \mathrm{~d}$ at 312 .

244. Id. at 575-78, $170 \mathrm{~A} .2 \mathrm{~d}$ at $311-13$.

245. Actually, there was a simpler basis for distinguishing the tort cases, which involved in one case a 16-year old, and in the other, a drunken person, since the actions of these persons might be regarded as sufficiently unfrce to permit the causal chain to be traced through them.

246. Root, $403 \mathrm{~Pa}$. at 583, $170 \mathrm{~A} .2 \mathrm{~d}$ at 315 (Eagen, J., dissenting). Very much the saine exchange of arguments occurred in another road race case where a bystander was killed. This tine the inajority affirmed the conviction. Jacobs v. State, 184 So. 2d 711 (Fla. Dist. Ct. App. 1966); see also People v. Keinp, 150 Cal. App. 2d 654, 310 P.2d 680 (1957).

247. See supra notes $48-50$ and accompanying text.

248. But see State v. Hopkins, 147 Wash. 198, 265 P. 481, cert. denied, 278 U.S. 617 (1928). 
death. ${ }^{249}$ The difficulty is this last-finding the lending of the car to be the cause of death. The driver's actions in causing the fatal accident would have to be found sufficiently nonvoluntary to allow the causal inquiry to trace through his intervening actions in driving the car. This may be possible if the driver were drunk enough, but it inay not be possible in many cases of driving under the influence.

The Russian roulette case differs from those we have been discussing, since the deceased's action of discharging the revolver at himself was precisely the act intended by the secondary party. But since complicity is unavailable so long as the deceased committed no crime in shooting himself, the issue presented is comparable to those we have been discussing: may the voluntary act of the deceased not be treated as an intervening cause because it was a probable consequence of the defendant's action? In the Russian roulette case, ${ }^{250}$ the court upheld a conviction of inanslaughter, relying on a plausible view of penal policy: "[T]he Commonwealth had an interest that the deceased should not be killed by the wanton or reckless conduct of himself and others."251 Indeed, it makes little sense from the standpoint of penal policy to hold the surviving player hable (as he certainly would be) if the game took the form of the players discharging the revolver at each other in turn, ${ }^{252}$ but not to hold him hable if each player fired at himself. But the case is not really distinguishable froin Root, despite the court's argument that it was, ${ }^{253}$ because both cases presented the same obstacle to causation liability, namely, the interverning volitional act of the deceased.

It is apparent that the grip of the conception that a voluntary human action bars assigning causal responsibility to an earlier actor, pervasive as it is in the law, is loosened by the pull of the policy of holding people hable for recklessly providing others with an occasion to do harnn. It is the saine policy that produced the pull to loosen the requirement of intentionality and to allow such persons to be held as accomplices. There is no way to extend liability in these cases through either doctrine in a

249. W. LAFAVE \& A. SCOTT, supra note 17, at 511-12.

250. Commonwealth v. Atencio, 345 Mass. 627, 189 N.E.2d 223 (1963).

251. Id. at 629,189 N.E.2d at 224 (citation omitted). But see supra note 241 (discussing Professor Williams' view).

252. Cf. Commonwealth v. Malone, $354 \mathrm{~Pa}$. 180, 47 A.2d 445 (1946).

253. The court sought to distinguish Root on the ground that in the road race casc much is left to the driver's skill (or lack of it), while in the Russian roulette case it is a matter of luck whether the revolver discharges. Commonwealth v. Atencio, 345 Mass. 627, 631, 189 N.E.2d 223, 225 (1963). But it is questionable that this is a relevant distinction. Perhaps it was thought more likely that harm would occur from the playing of Russian roulette than from engaging in the road race, since in the latter the deceased competitor may not take outrageous risks while driving, or might safely extricate himself if he did. But the decision in Root explicitly conceded that defendant's actions were reckless enough to constitute manslaughter if he could be said to have caused the death. Root, 403 Pa. at 573-74, 170 A.2d at 311 . 
way that does not require a significant departure from doctrinal premises, and, indeed, some courts have done just that.

Removing the requirement of intentionality for complicity has the major drawback of exposing a reckless actor to liability for a crime committed by another which requires a higher mens rea. While it is possible to confine the secondary party's liability to crimes of recklessness, there is the ever present danger of the doctrine spilling over beyond such limits. ${ }^{254} \mathrm{~A}$ furtlier drawback of making complicity applicable in tliese cases is the very weak but-for showing that suffices (the mere possibility of a but-for relationslip), ${ }^{255}$ as compared to the showing required to establish causation liability.

Developments in the law of torts, on the other hand, offer a wellestablislied precedent for modifying proximate cause principles to impose liability on a defendant for harm caused by another where the defendant negligently provided him with the opportunity to do the liarm. In torts the novus actus interveniens principle has yielded to the principle of foreseeability. If the voluntary and intentional action of anotlier was one of the risks in virtue of which the defendant's conduct was negligent, it is regarded as foreseeable and not, therefore, as a superseding cause. ${ }^{256}$ Under this principle it is plain tliat tort liability for damages could be inposed on the defendant in each of the situations discussed in this Section: on the defendant wlio lent his car to a driver he knew to lave been drinking or to be incoinpetent, on the road race survivor, and on the Russian roulette game survivor. Many will regard it as quite appropriate that criminal liability for 1nanslaughter should also be imposed. ${ }^{257}$ Indeed, one legislative proposal sought explicitly to adopt the tort standard for criminal cases by establishing causal responsibility when the result was within the risk of which the defendant should have been aware, "whether that risk extends to natural events or to the conduct of another."258

An arguable difficulty with this approach is that it could extend the

254. See supra text accompanying notes 64-73.

255. See supra text accompanying notes 85-96.

256. The Second Restatement of Torts asserts: "If the likelihood that a third person may act in a particular manner is the hazard or one of the hazards which makes the actor neghigent, such an act whether innocent, negligent, intentionally tortious, or criminal does not prevent the actor from being liable for harm caused thereby." RESTATEMENT (SECOND) OF TORTS $§ 449$ (1965); see id. $\S \S 302 A$, 302B; W. Keeton, D. DobBS, R. Keeton \& D. OWen, Prosser and KeEton on the LAW of TORTS $\S 33$, at 201-03, $\S 44$, at 302 (5th ed. 1984).

257. An argument for extending the concept of causation to cover cases where a defendant recklessly or negligently facilitates another person's criminal conduct, even when it is wholly volitional, is made in Note, Causation in the Model Penal Code, 78 Colum. L. Rev. 1249, 1277-84 (1978). The author also argues that the causation provisions of Model Penal Code $\S 2.03$ provide for such liability.

258. Cal. Joint legislative Comm. for Revision of the Penal Code, Penal Code Revision Project $\S 408(1)(b)$ (i) (Tent. Draft No. 2, 1968). I should disclose my role as the 
reach of the criminal law to include cases where the justification for crininal punishment might seein less coinpelling than in the cases we have discussed in this section. ${ }^{259}$ On the other hand, the significantly greater culpability requirement for criminal negligence inight serve to keep criminal liability within bounds. And in any event, causal responsibility has already been extended in accordance with the tort principle when the primary actor's act is not wholly volitional, as we saw in the previous Section, and the problem of the reach of the criminal law is hardly different depending on the volitionality of the primary actor's conduct. ${ }^{260}$

\section{Closing Comments}

I have tried to show im Parts I and II of this Article that the variety of rules and principles constituting the Anglo-American common law doctrine of complicity manifest a conceptual unity. That is to say, to a significant degree they follow from certain fundamental propositions.

These propositions are not arbitrary. They flow from central features of the way we experience the external world and our part in it. In that experience, as reflected in our social practices, our language, and our intuitive perceptions, there is a dichotomy between nature and will. Connections between events in nature are subject to relentless forces. Whether explained as the work of the gods or as the physical laws of the universe, the sense of their being beyond human power is the same. We inhabit the natural world and are therefore subject to it. But we also stand outside it. As persons, with our individuality, we confront the natural world with our own selves. In what we choose to do, as opposed to what happens to us, we are free and autonomous actors.

These perceptions have a shaping influence on our conception of responsibility, including, of principal interest for this Article, the assignnient of blame for untoward results that happen as a consequence of our actions. Responding to these perceptions, our law has developed two separate bodies of doctrine to deternine responsibility for results: causa-

Reporter responsible for this draft. It seemed to me at the time to represent desirable legislative policy. I still thimk so, but with less certainty.

259. Consider the following cases in which tort liability has been imposed: Kendall v. Gore Properties, Inc., 236 F.2d 673 (D.C. Cir. 1956) (landlord held negligent in killing of tenant by employee whose background he did not sufficiently investigate); Liberty Nat'l Life Ins. Co. v. Weldon, 267 Ala. 171, 100 So. 2d 696 (1957) (insurer that issued policy on life of child to one without insurable interest in child held negligent when child was murdered by beneficiary); Weirum v. RKO Gen. Inc., 15 Cal. 3d 40, 539 P.2d 36, 123 Cal. Rptr. 468 (1975) (radio station held hable for careless driving by fans trying to win award for being the first person to locate roving disc jockey). For further cases, see RESTATEMENT (SECOND) OF TORTS § 449 app. (1966 \& Supp. 1983).

260. Consider the case of a police guard who negligently leaves his gun in the open waid of a mental hospital. If an incompetent person uses the gun to kill, the criminal law permits the guard to be held for manslaughter on a causation theory. There is no greater peril to ordinary behavior if the guard is also inade hable when a competent visitor uses the gun to kill. 
tion, for the realm of nature, and complicity, for the realm of will. Causation deals with results of a person's action that happen in the physical world. Complicity deals with results that take the form of another person's voluntary actions.

The reason why complicity emerges as a separate ground of liability is that causation doctrine cannot generally deal satisfactorily with results that take the forn of another person's voluntary action. This is so because the voluntary action of a primary party cannot appropriately be said to have been caused (in the physical sense of cause) by the action of the secondary party. As Hart and Honoré's study has shown, a voluntary action is treated as the terminal point of a causal inquiry beyond which the inquiry does not usually proceed. The primary party's voluntary act is his own action. No one and nothing caused him to act as he did. He chose to act. Thus the basic premise of the concept of responsibility itself is the ultimate ground for the distinction between causation and coinplicity.

This account of the provenance of complicity doctrine serves to explain a number of its central features, as well as its contrasts with and similarities to causation doctrine.

First, a person may be held accountable for a result under the doctrine of causation on the basis of any action that satisfies sine qua non and proxinnate cause requirements. A person may be held accountable for the unlawful action of another, however, only for two kinds of action-actions that influence the decision of the principal to commit the crime or that help him to do so. This is because only these forins of affecting the conduct of the principal are consistent with the notion of the principal having freely chosen to act as he did.

Second, since the principal has committed a crine through his own voluntary conduct, that conduct can not be attributed to the secondary party, who inay have influenced or helped, but did not cause the principal's action. Therefore the secondary party can not be regarded as having committed the substantive crime. The principal has committed the crime and the secondary party becomes legally accountable for it by virtue of the doctrine of complicity. If the principal has committed no violation, there is no ground for imposing liability on the accomplice. In this sense accoinplice liability is derivative, or dependent, rather than direct, as causation liability always is.

This derivative character of the accomplice's liability explains a variety of outcoines in the law of complicity. It explains, for example, the liability of an accoinplice for a crime committed by a principal where the crime is so defined that the accoinplice is incapable of committing it, the nonliability of the secondary party where the primiary party is feign- 
ing involvement, and the difficulties encountered by courts in holding the accomplice for a crime greater than that of the principal.

The most problematic feature of the theory of derivative liability is determining the legal status of the principal's action required to impose hability on an accomplice who aids or influences him. The classic common law position is that the principal's action must incur liability. But, as we saw, the requirement has been loosened to make it sufficient that the principal committed a culpable violation of law, though he could not have been held criminally hable for it. A further loosening, arguably not yet part of common law doctrine, but adopted in German law, would dispense with the requirement of a culpable principal so long as the principal committed a wrongful act. None of these modifications, however, contradicts the premise of derivative liability.

Third, in contrast to causation doctrine, which allows for liability for neghigent (even accidental) as well as intentional actions, the normal principle of comphicity doctrine requires that the accomplice intend the culpable conduct of the principal. It is not completely clear that this requirement is entailed in the core suppositions of complicity doctrine. I have surimised that intention may serve as the analogue of consent, which in the law of agency is the standard mode whereby a principal is inade accountable for the obligations incurred by his agent. This would explaim the absence of the intent requirement in causation. The standard requirement of consent (or intent), it may be further surmised, has its roots also in the conception of the autonomy of human action: What another freely chooses to do is his doing, not mine. It cannot be seen as a part of my action the way a natural physical consequence would be. Only if I chose to identify with his action may I incur the liability that action creates.

Fourth, complicity and causation are cognate concepts in the sense that they both govern when a person's actions may be blained for a consequence. Both require at a minimum that the person's conduct succeed in contributimg to the result, that it make a difference to what happened. In causation this is expressed in the requirement that the action be a sine qua non condition of the result. In complicity, however, this need not be establislied. The reason is not that an accomplice inay be liable for the crime of another even if his action made no difference. The reason is rather that the requirement of a sine qua non condition becomes attenuated in complicity to the requirement of a possibility that it was a sine qua non condition, because im cases of influence, in contrast to aid, that is all that can be established.

This follows again from the different ways we conceive of physical events and voluntary actions. While events in the physical world are governed by laws of nature that imply the existence of necessary and 
sufficient conditions, voluntary decisions to act are not. They are controlled by the choice of the actor, a "wild card," for whose action no set of conditions is sufficient and no condition is necessary, save the conditions of a free act of will. Therefore, though it inay be in any particular case that the principal would not have chosen to act without the influence of the accomplice, it is never so as a matter of necessity, since the principal could have chosen otherwise. All we can say as a matter of necessity is that in the one case where the influence fails to reach its target it could not possibly have inade a difference and hence may be ruled out as a sine qua non condition.

In other respects, where differences are not coinpelled by the naturewill distinction, causation and comphcity inquiries run parallel courses, as their cognate functions would lead one to expect. In order to attribute causal blame to an actor more is required than a but-for relationship between his action and the result; his action must be a "legal" or "proximate" cause, meaning that the result must not be accidental or abnormal or one directly produced by intervening voluntary actions of others. Similar restrictions preclude complicity hiability even if the possiblity of a but-for relation exists. This is evident most clearly where the primcipal voluntarily departs from the conduct the secondary party intended, but it would also be true where the contribution of the secondary party, even to what was intended, works out in abnormal or accidental ways.

Part III considered the complementarity between complicity and causation. Complicity is not the exclusive ground for determining the liability of one person for what another does. Causation may also serve that purpose. It does so where the action of the primcipal is not fully voluntary, such actions being seen as belonging sufficiently to the realm of nature to permit analysis in terms of causation. Causation therefore serves to complement complicity, whose function is to goveru cases of fully voluntary actions.

Causation is relied on to perform this coinplementary office mainly in two situations. One is where the principal has a defense that negates his culpability. The absense of a basis for derivative hability makes complicity doctrine inappropriate. However, causation doctrine becomes appropriate to the extent that the factors that negate the principal's culpability also negate the voluntary character of his action. This suffices to establish the secondary party's liability for a result crime. He may be held liable for an action crime as well where the instigator intentionally uses the principal to coinmit the crime, on the theory that he commits the proscribed action through the instrumentality of the innocent primcipal (the innocent-agency theory).

The other situation where causation complements complicity is that in which complicity fails because the secondary party does not intend the 
criminal conduct of the principal. So long as the action of the principal is not fully volitional, causation doctrine allows tracing the results of his conduct through him to the secondary party, whose culpable act in some sense invited the crimimal conduct of the principal, even though he did not intend it.

But the fit between causation and coinplicity turns out to be imperfect. In soine cases neither doctrine suffices to impose a liability which seems otherwise appropriate, and courts quite naturally nay be observed striving to impose hability.

One such situation is where the nature of the prohibited action (nonproxyable actions) or the limitation of the class of persons capable of violating the prohibition precludes holding an instigator liable for the crime under the innocent-agency theory. Courts have often had to exceed doctrinal himitations in imposing habihty in these situations. The source of the difficulty may perhaps be regarded as a defect in causation or complicity doctrine, but it is inore accurately stated as the absence of a general ground of crimmal liability based on causing another to do a prohibited act. Legislative provision of such a ground (as the Model Penal Code has proposed) entails no inconsistency with complicity or causation doctrines as I have interpreted them. Another case of this kind occurs where the secondary party tries but fails to contribute to the criminal action of the primary party. No inconsistency with the theory of coinplicity is created in providing for liability based on attempt (as again the Model Penal code has proposed) any inore than one is created with causation doctrine by the traditional provisions for liability based on atteinptimg to cause a result.

The other main situation where the fit between causation and complicity is arguably imperfect is that in which the secondary actor unintentionally contributed to a wholly volitional criminal action of a primary party. This differs significantly froin the situations treated in the preceding paragraph because the discrepancy arises from the character of complicity and causation doctrines. Inposing liability would have to entail some inconsistency with these doctrines, as I have suggested they be understood. An exception would need to be made either to the requirement of intentionality for comphicity liability, or to the principle that a fully voluntary action can not be regarded as caused by a previous actor. This obviously raises a problem for the theory of these doctrines as I have presented it.

If the sense behind imposing liability in these cases is that public policy requires it, regardless of the inappropriateness of blaming the defendant, there is no difficulty. Nothing I have proposed is inconsistent with public policy judgments overriding the constraints of appropriate blaming. If, on the other hand, it is deeined consistent with those con- 
straints to impose hability, then I am presented with a counterexample to my interpretations: eitler intent is not always a requirement of complicity, or a voluntary act can sometimes be caused.

There is a strong case to be made that in some situations it is both sound in policy and conformable to our intuitions of just blaming to lold a person liable for recklessly facilitating the criminal action of another. Soine courts liave made that case and some legislation rests on it, the judgment being expressed eitler by a doctrine of reckless complicity or by one that accepts the principle that voluntary actions can be caused. This is an important cliallenge to the doctrinal interpretation I have offered, particularly when expressed in the latter way. But it is not necessarily a serious one for the following reasons.

First, there is strong resistance to the case for extending liability in these situations and much law is the other way. It is fairer to say, therefore, that the law reflects ambivalence on the issue, rather than to say flatly that voluntary actions can be caused. Second, that we are sometimes prepared to treat anotlier's voluntary action as liaving been caused is not inconsistent with a general reluctance to do so, or with the view that thiat reluctance is reflected in the provenance and sliape of complicity doctrine. ${ }^{261}$ Third, the strong evidence in support of that premise, to be found in its power to explam many features of complicity doctrine, is not seriously undermined by evidence that we sometimes find it acceptable to blame a person for unintentionally causing anotler's voluntary action. There is reason to expect that our social experience in blaming for results should be broadly responsive to several fundamental propositions. There is no reason to expect that anything so human and subjective should exist witlout some tension and even contradiction.

Let me now conclude with a general perspective of the cliaracter of the enterprise I have undertaken.

The notion that law lias an existence independent of the society of which it is a part-a "brooding oinnipresence in the sky"-is no longer thouglit at all credible, if it was ever really believed. People who worry about sucl things entertain strongly differing views of the nature of law, but few doubt that law, and assuredly the criminal law, is an instrument for attaining certain purposes. Some see it more or less neutrally as an instrument for maintaining the conditions of social living; otliers see it less neutrally as an instrument for furthering the interests of the powerful. Some see its purposes fulfilled by positive enactments designed to

261. Cf. H.L.A. HART \& A. HoNORE, supra note 5, at 357:

[W] hatever else may be vague or disputable about common sense in regard to causation and responsibility, it is surely clear that the primary case where it is reluctant to treat a person as having caused harm which would not have occurred without his act is that where another voluntary human action has intervened. 
achieve preferred states of affairs; others see it as a working out of fundamental moral principles whose roots are to be found either in the nature of things or in the morality embedded in particular political structures and practices. But that the law is man-made for man's purposes is not an issue in serious dispute, nor could it be.

But to concede so much is not to deny that law may have other important features as well. Law is the product of deliberate decisions, but it is also a product of our culture, through which we express our deepest preoccupations with the world in which we live and our perceptions of its nature and of our own. It is familiar to regard our literature, art, legends, ceremonies, religion, and other cultural forms as vehicles of expression of this kind. But it is no less true of law; of the law's institutions, structures and practices, no doubt in many ways, but also of its bodies of substantive doctrine. Doctrinal law is a cultural product as worthy of being interpreted from the perspective of the social anthropologist as the cultural forms conventionally studied for this purpose, In this Article, I have tried to make this claim good for one small segment of legal doctrine, the doctrine of complicity in the crimmal law. 